

This book is dedicated to Roreta.

May you find what you are looking for in your new life in a new place. 



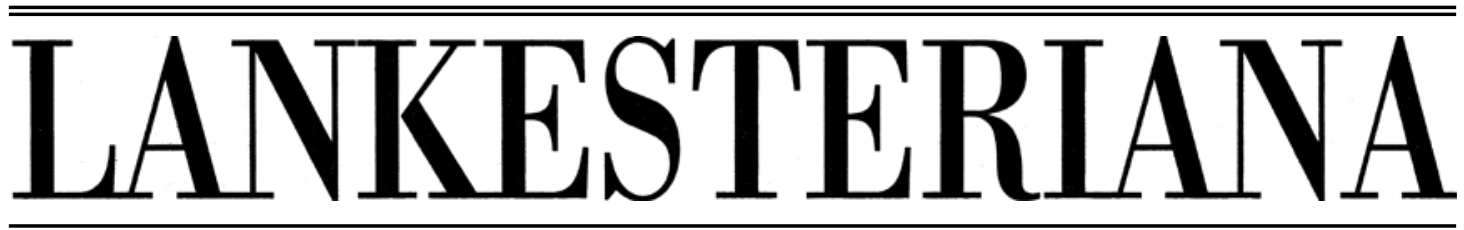

VOL. 11, No. 2

AUgUST 2011

The Orchids of Tonga, Niue, and the Cook Islands

Phillip J. CribB and W. Arthur Whistler 


\section{LANKESTERIANA}

INTERNATIONAL JOURNAL ON ORCHIDOLOGY

Copyright $(2011$ Lankester Botanical Garden, University of Costa Rica

Effective publication date: August 23, 2011

All photos were taken by Art Whistler, except for Acanthephippium splendidum, which was kindly provided by Josh Seamon, and Liparis clypeolum, which was provided by David Lorence.

Layout: Jardín Botánico Lankester.

Cover: Habenaria amplifolia, endemic to the island of Rarotonga.

Printer: S\&F Printing Solutions S.A.

Printed copies: 500

Printed in Costa Rica / Impreso en Costa Rica

R Lankesteriana / International Journal on Orchidology

No. 1 (2001)-- . -- San José, Costa Rica: Editorial

Universidad de Costa Rica, 2001--

v.

ISSN-1409-3871

1. Botánica - Publicaciones periódicas, 2. Publicaciones periódicas costarricenses

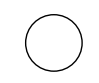




\section{TABLE OF CONTENTS}

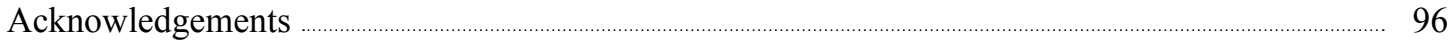

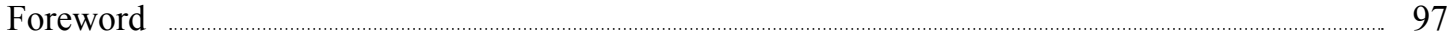

The Orchids of Tonga, Niue, and the Cook Islands _............................................................................................ 99

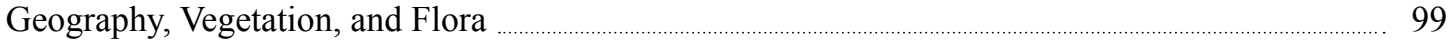

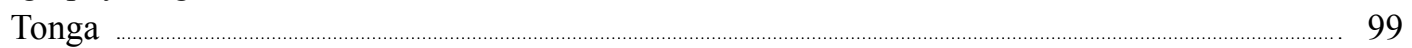

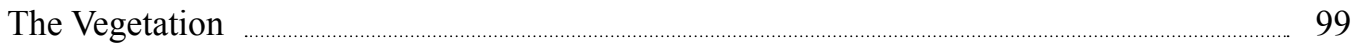

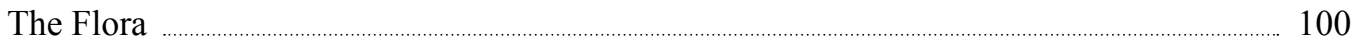

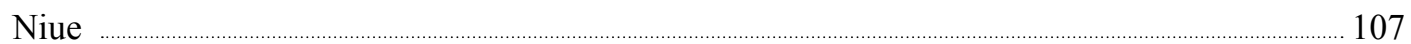

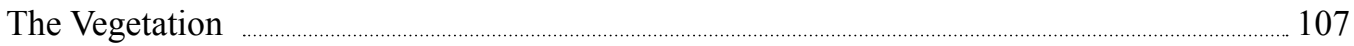

The Flora $\ldots \ldots$

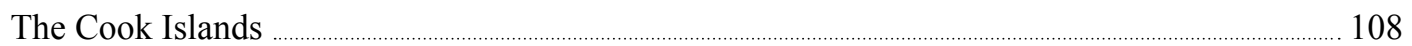

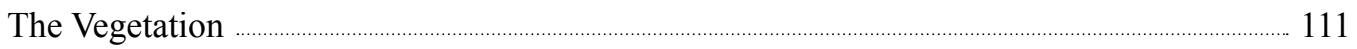

The Flora

The Orchids $\ldots$

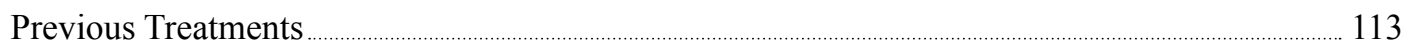

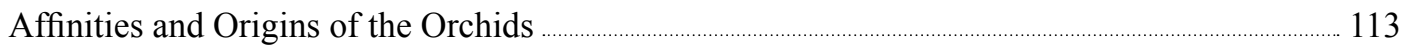

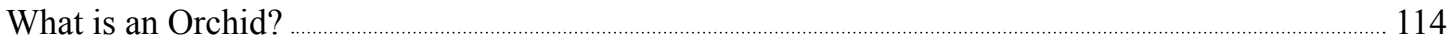

The Plant $\ldots \ldots \ldots$

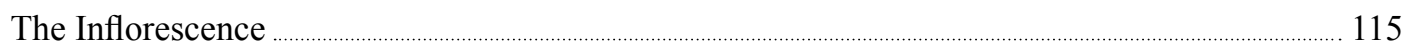

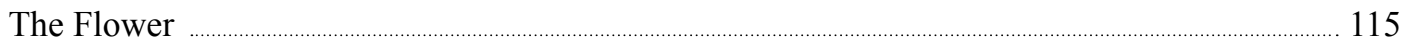

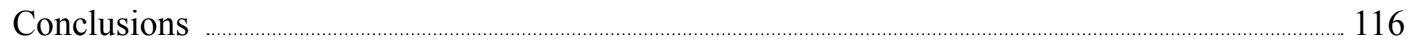

Orchidaceae

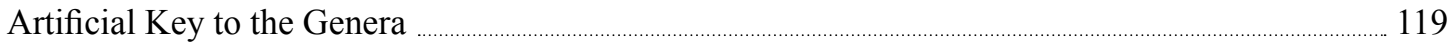

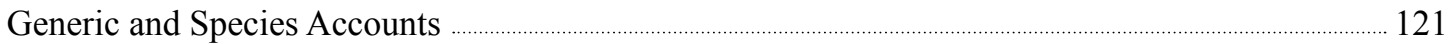

References

Index to Scientific Names ................................................................................................................ 175 


\section{ACKNOWLEDGEMENTS}

We would like to thank Paul Ormerod and Jeffrey Wood for their help on taxonomic matters; the late G. Hermon Slade and Gerald McCraith, who stirred the interest of the lead author; and Oliver Whalley for the line drawings and maps. We are also grateful to Paul Ormerod for extensive comments and advice on the manuscript; Dr. David Lorcence of the NTBG for his facilitation of this publication; Clyde Imada of the Bishop Museum, who kindly proof-read the manuscript; and the curators of the following herbaria for access to, or the loan of, specimens: AMES, BISH, BM, G, HAW, HBG, K, P, UC, W, Z. 


\section{FOREWORD}

Orchids are one of the largest families of flowering plants in the Pacific region, especially in the tropics. Despite the remoteness of Tonga, Niue, and the Cook Islands, orchids have reached them in some numbers. Both terrestrial and epiphytic genera are well represented in the floras of these distant but neighboring archipelagos. Most of the species are found elsewhere in the Pacific, particularly in Fiji, Samoa, and the Society Islands. The affinities of these orchids can be traced to New Guinea and the adjacent archipelagos. New Guinea, with an estimated 3000 species that make it one of the richest orchid floras in the world, is a fertile source of seed for the scattered islands that lie to its east and southeast. The orchids appear to have reached Tonga, Niue, and the Cook Islands in recent times. Only two species, Habenaria amplifolia from Rarotonga and Robiquetia tongaensis from Tonga, are endemic to the islands covered in the present book, and both are closely related to more widespread Pacific species.

This guide constitutes the fourth of a series of orchid floristic treatments that have so far covered Vanuatu (Lewis \& Cribb 1989), the Solomon Islands and Bougainville (Lewis \& Cribb 1991), and Samoa (Cribb \& Whistler 1996). A recent, excellent and detailed account of the Fijian orchid flora (Kores 1991) has also been a valuable source for those interested in Pacific islands orchids. These accounts have generated renewed interest in the orchid floras of those archipelagos, leading to new discoveries and re-interpretations of several species. We hope that this small guide will likewise bring a renewal of interest in not only the orchids, but also the floras of these islands as a whole.

Phillip Cribb, W. Arthur Whistler February 2011 
LANKESTERIANA 


\title{
THE ORCHIDS OF TONGA, NIUE, AND THE COOK ISLANDS
}

\author{
Phillip J. CribB ${ }^{1} \&$ W. Arthur Whistler ${ }^{2}$ \\ ${ }^{1}$ Royal BotanicGardens, Kew, Richmond, Surrey, TW9 3AE, U.K. P.Cribb@rbgkew.org.uk \\ 2Botany Department, 3190 Maile Way, Honolulu, HI 96822, U.S.A. whistler@hawaii.edu
}

\section{GEOGRAPHY, VEGETATION, AND FLORA}

\section{Tonga}

Tonga, which lies at a latitude of $15-23^{\circ} \mathrm{S}$ and a longitude of $173-177^{\circ} \mathrm{W}$, comprises about 150 islands with a total area of $697 \mathrm{~km}^{2}$, with only about 36 of these islands currently inhabited. The islands of the archipelago are mostly coralline and "continental," and lie on the eastern edge of the Asia-Australia Plate. The archipelago forms a double chain of islands running in a north-northeast direction with small, high, volcanically active islands to the west, and lower, larger, raised coral islands to the east. Uplifting of the edge of the Asia-Australia plate caused by subduction of the Pacific Plate under it has created the eastern limestone islands and resulted in volcanic activity that in turn created the western chain of volcanic islands. Ash from ancient volcanic eruptions later covered most of the limestone surface of the rest of the archipelago, resulting in deep fertile soil on many of the islands. Volcanic activity continues today in the western chain — on Tofua and Fonualei, and on underwater volcanoes that periodically erupt and come to the surface.

The main limestone islands are Tongatapu (257 $\mathrm{km}^{2}$ in area, $80 \mathrm{~m}$ elevation; Fig. 1), 'Eua (87 $\mathrm{km}^{2}, 330$ m; Fig. 2), and Vava'u (90 km², 200 m; Fig. 3). Numerous small, raised limestone islands known collectively as Ha'apai lie between Tongatapu and Vava'u. In the volcanic chain, the main islands of the southern part, going from south to north, are 'Ata, Tofua (Fig. 4), Kao (Fig. 5), Late, and Fonualei; all of these are uninhabited (but Tofua often has a small temporary population). Kao, which lies adjacent to Tofua, has the highest elevation in Tonga (1046 m). The northern part of the volcanic chain comprises three islands, Niuafo'ou (Fig. 6), Niuatoputapu (Fig. 7), and Tafahi (Fig. 8), all of which are inhabited (See Figs. 63 \& 64.)

Since Tonga is situated between the Tropic of Capricorn and the equator, its climate is tropical. There is little seasonal or diurnal temperature variation, although the winters are sometimes relatively cool. The average yearly temperature in Nuku'alofa on Tongatapu is $23^{\circ} \mathrm{C}$, with an average low of $22^{\circ} \mathrm{C}$ and an average high of $26^{\circ} \mathrm{C}$. The islands to the north, i.e., Ha'apai and Vava' $\mathrm{u}$, are a little warmer since they are closer to the equator. There is no pronounced dry season, but 60 to $70 \%$ of the rainfall occurs in the "wet" season (December to April). The southern islands average about 1700 $\mathrm{mm}$ of yearly precipitation, while the northern islands average about $2600 \mathrm{~mm}$.

The vegetation. There have been several recent vegetation studies in Tonga, the earliest of which was a brief paper on the forests of 'Eua (Straatsmans 1964). A more recent and comprehensive study of the vegetation of 'Eua was done by Drake et al. (1996). Ten primary and secondary vegetation types were recognized on that island, and the best remaining lowland forest in Tonga is found in the 
limestone areas that comprise the southeastern part of the island. Two other vegetation studies on Vava'u were carried out by Steadman et al. (1999a, 1999b). There have been three vegetation studies on Tongatapu, which has been highly disturbed by centuries of occupation and cultivation. The first was by Palmer (1988) on the only remaining patch of (disturbed) lowland forest on the island, and the second by Ellison (1990) on the vegetation of the Tongatapu outliers. The third was by Wiser $e t$ al. (2002), who studied forest fragments on the island. Whistler (1992) discussed the similarities of the vegetation of Samoa and Tonga.

Uhe (1974) published an analysis of the vegetation of the volcanic areas of Niuafo 'ou, the only such study of the volcanic islands of Tonga. Sykes (1981) reported on the vegetation and flora of Late, but did not include any quantitative data. A comprehensive field study of the vegetation and flora of Kao and Tofua was carried out in 1982 by G. Buelow, but his work was discontinued and never published. More recently, however, a botanical survey was carried out in Ha'apai, with particular emphasis on Kao and Tofua (Park \& Whistler 2001), since that area had been selected to be a conservation area. The uninhabited volcanic islands, especially Tofua, have some areas of undisturbed lowland forest. Cloud forest (Fig. 9), which is home to many of the Tongan orchid species, is found only on Tafahi, which is the second highest island of the archipelago. A ferndominated vegetation on top of Kao (Fig. 10), the highest elevation in Tonga (1046 m), is also home to many orchids, especially terrestrial species, since trees are few in that habitat. A comprehensive description of the vegetation of the archipelago is found in the work by Mueller-Dombois and Fosberg (1998) on the vegetation of the Pacific Islands. Herbarium abbreviations cited herein follow those used in Index Herbariorum [http://sweetgum.nybg.org/ih/herbarium_list.php].

The Flora. The first botanical collections in Tonga date to the three Captain Cook expeditions (1773, 1774, 1777), and are stored at Kew (K). The next large collection was not made until over 60 years later, when the U.S. Exploring Expedition (USEE) visited Tonga in 1840 (Pickering 1876). This collection is housed mostly at the Smithsonian Institution (US). Another half century passed before further major collections were made-J.J. Lister (Hemsley 1894), who botanized in Tonga in 1888-1891, and C.S. Crosby (Burkill 1901), who botanized there in about 1894. These collections are stored at Kew. Another large collection made by H.E. Parks in 1921, which is stored at Kew, the University of California, Berkeley (UC), and the Bishop Museum (BISH) in Honolulu, has only been partially published (Yuncker 1959).

The five largest Tongan collections (which include between 1000 and 3300 specimens) have been made in the last sixty years. The first of these was by T.G. Yuncker in 1953, who, on the basis of his specimens and those of an earlier collector (Hurlimann in 1951), published a flora, Plants of Tonga, in 1959. Yuncker's collections are stored at the Bishop Museum. Another major Tongan collection was made by M. Hotta in 1961, but the manuscript of his work (Hotta 1962) has never been published. His specimens are stored in Kyoto (KYO), Japan.

More recently, G. Buelow, who worked in Tonga between ca. 1977 and 1982, compiled by far the largest collection of anybody ( $c$. 3300 numbers), but his work has never been published. His specimens are stored at Christchurch (CHR), New Zealand, and the Bishop Museum. At about the same time another significant, but smaller, collection was made by W.R. Sykes, which is a basis for his fern study of 'Eua (Sykes 1977) and a vegetation study of Late (Sykes 1981). However, Sykes' collection numbers to his specimens, which are stored at Christchurch, have never been published. The most recent large collection of Tongan plants was made by the present co-author (Whistler) 


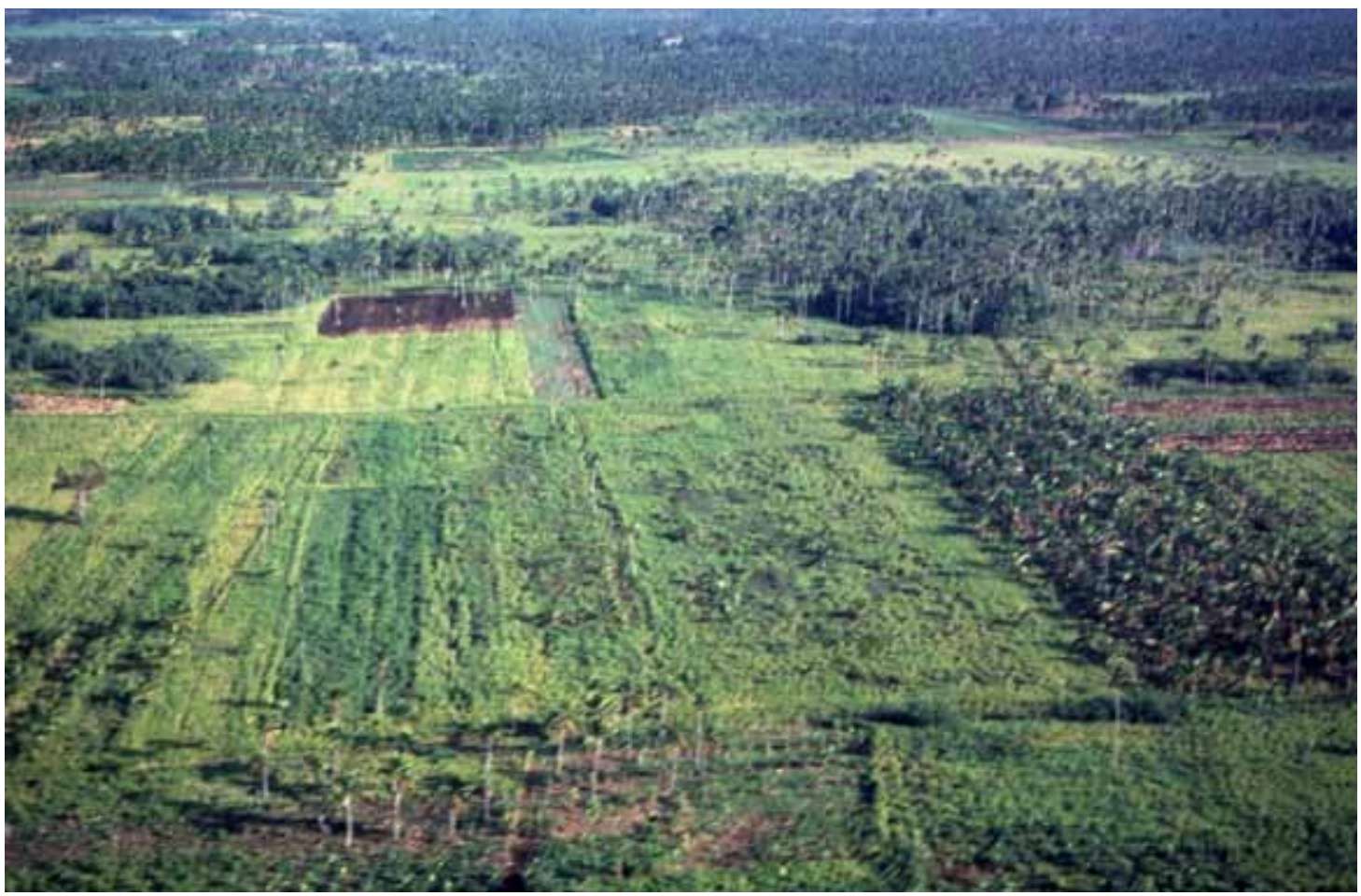

FIGURE 1. Tongatapu.

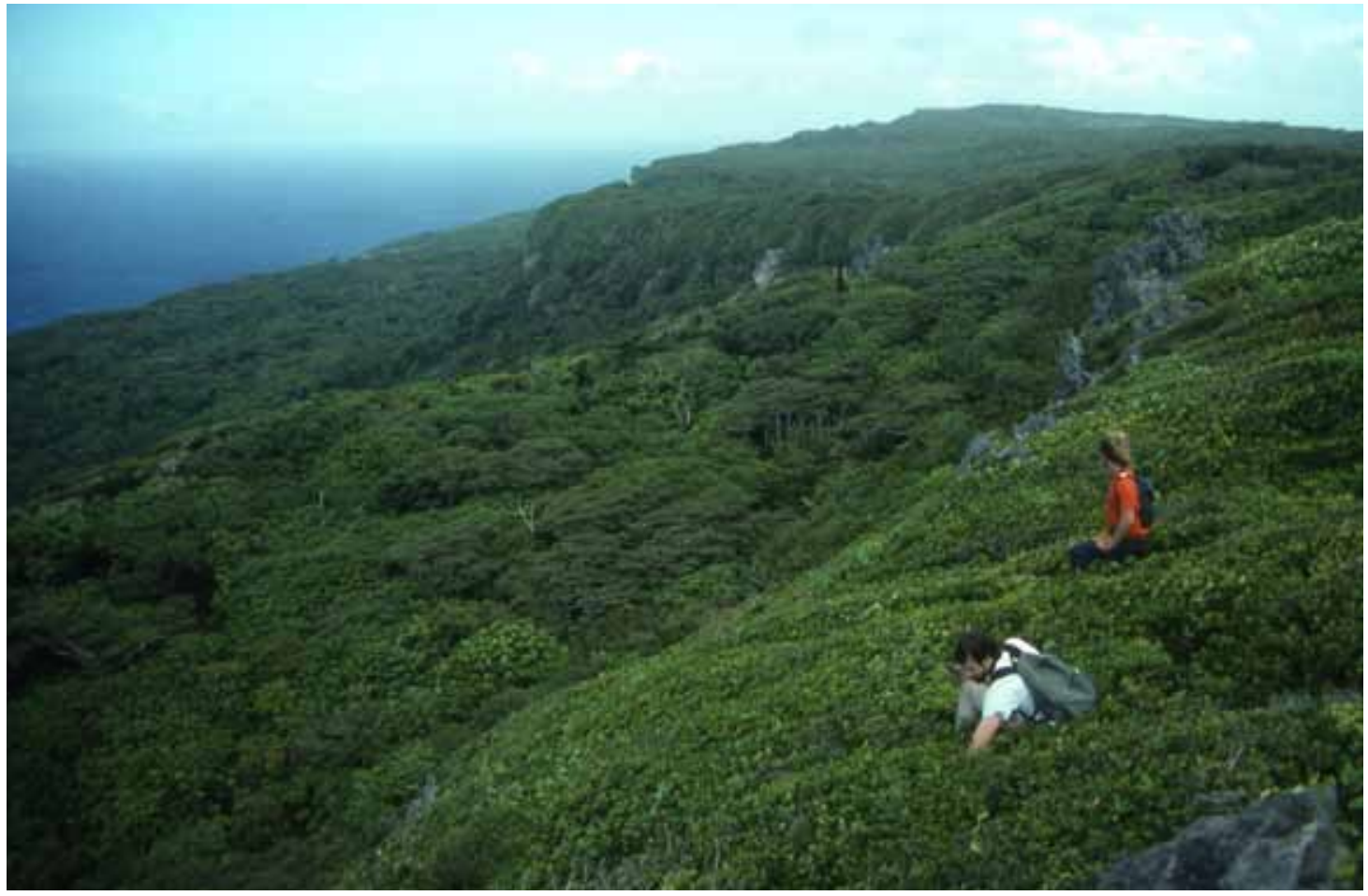

FIGURE 2. Eua. 


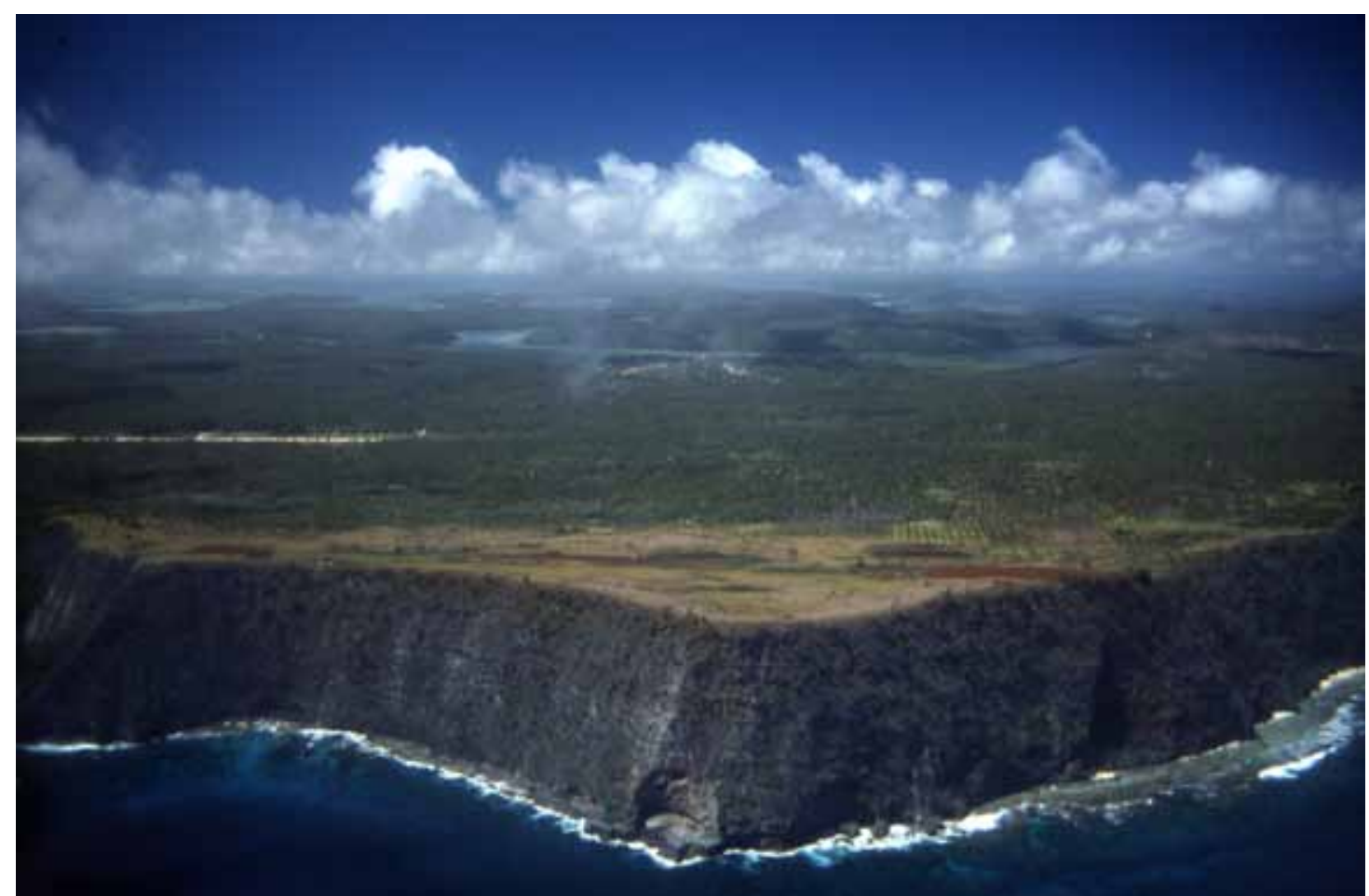

Figure 3. Vava'u.

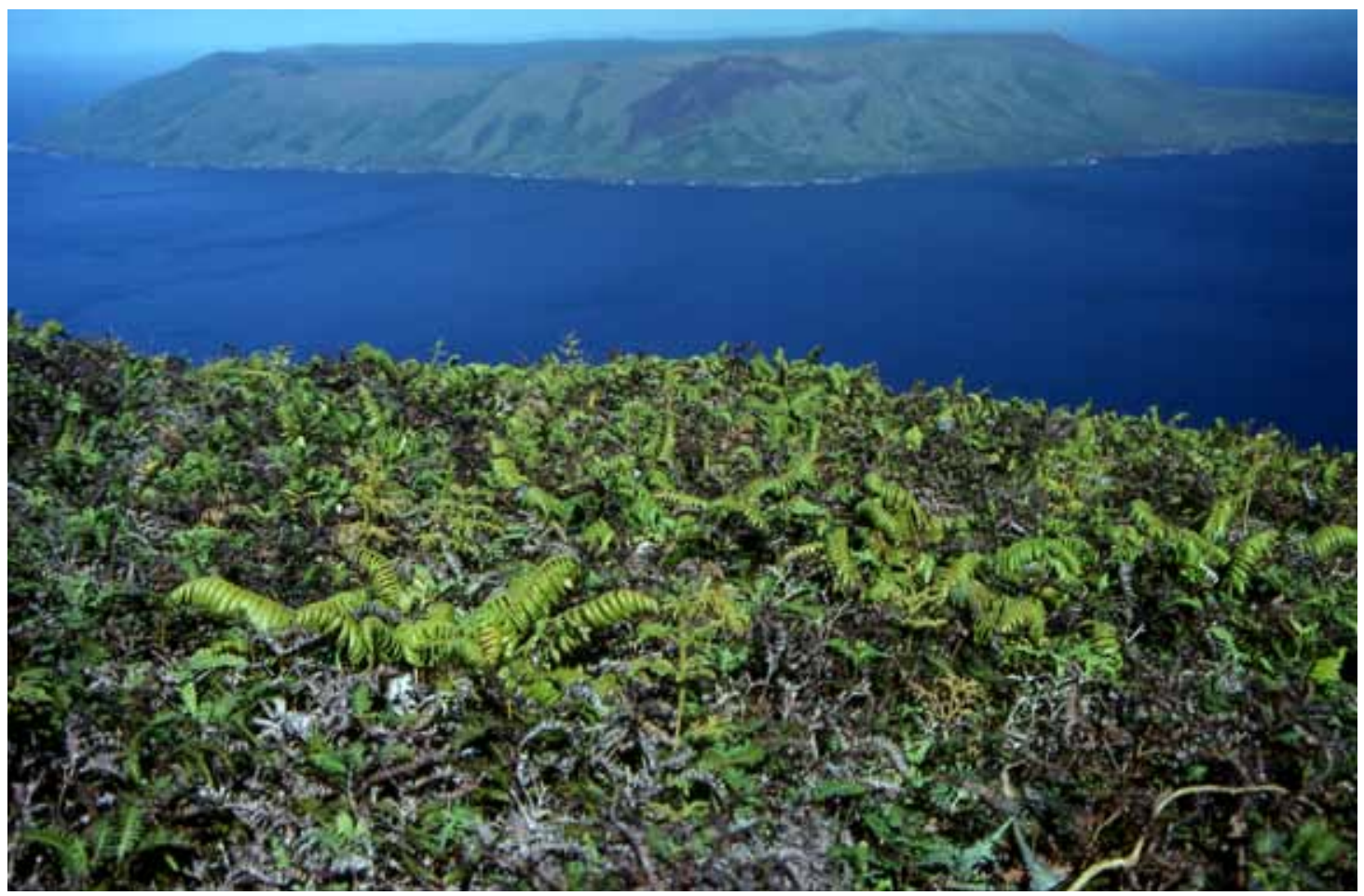

Figure 4. Tofua.

LANKESTERIANA 11(2), August 2011. (C) Universidad de Costa Rica, 2011. 


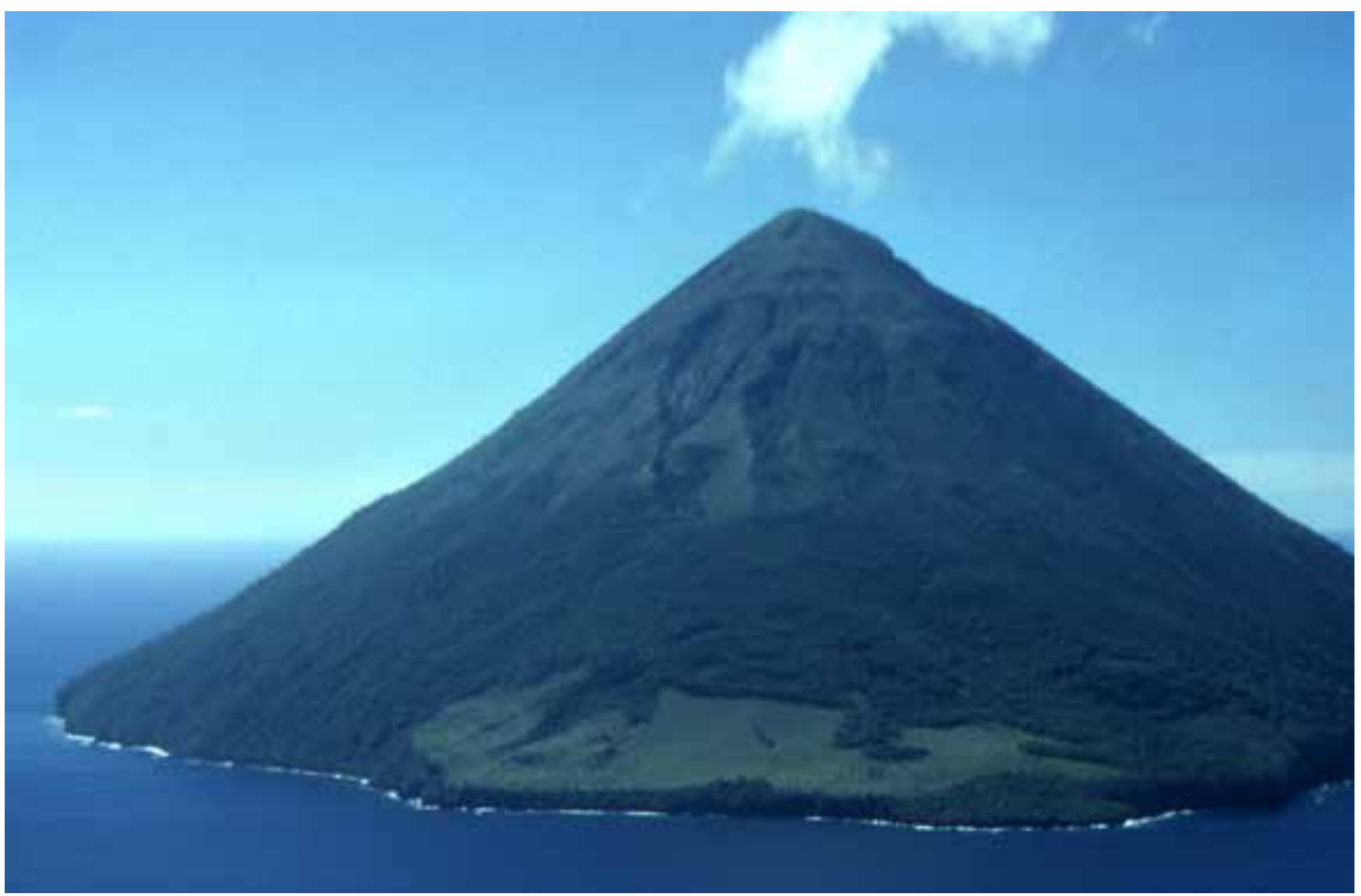

FiguRE 5. Kao.

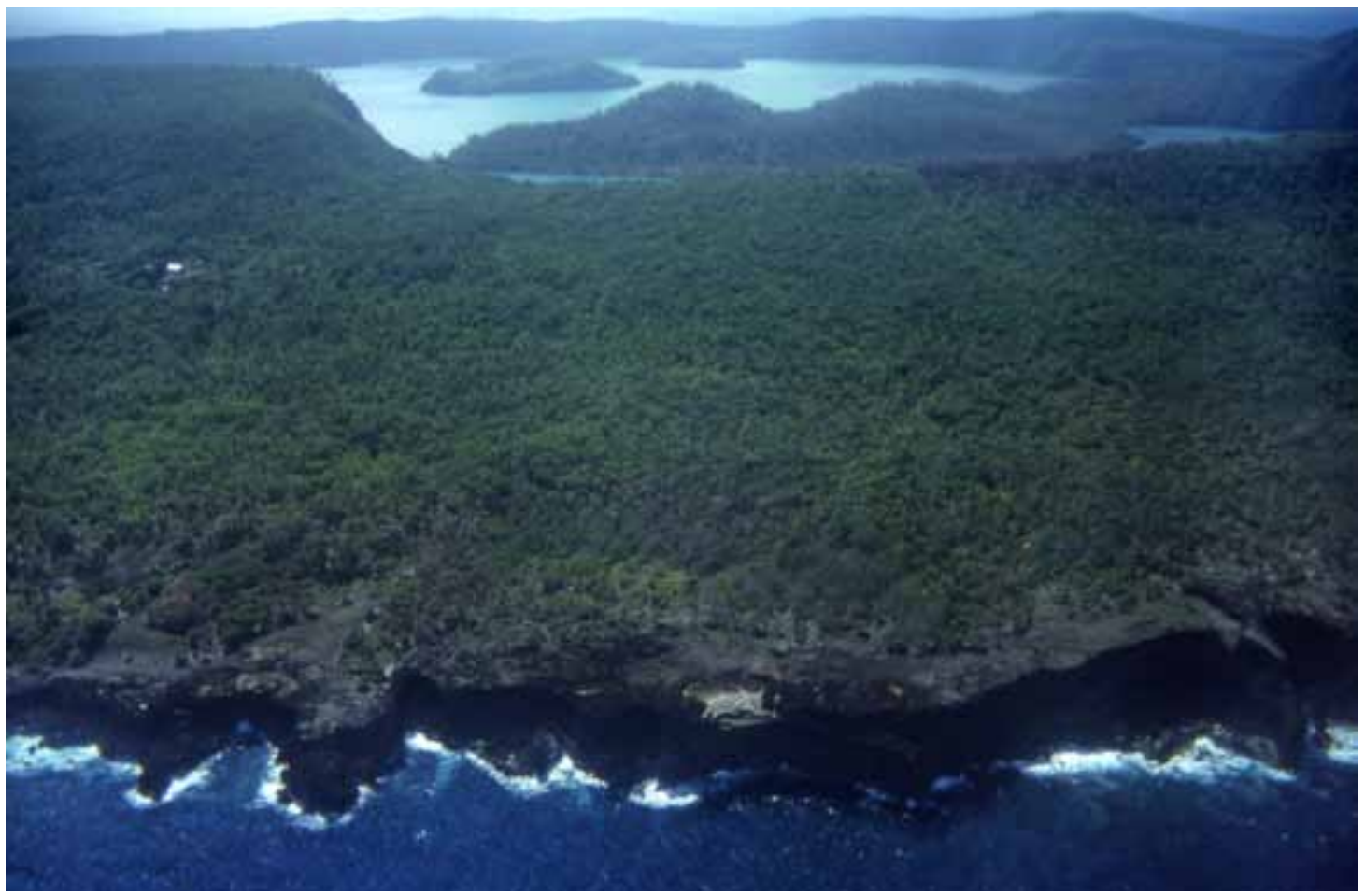

Figure 6. Niuafo‘ou. 


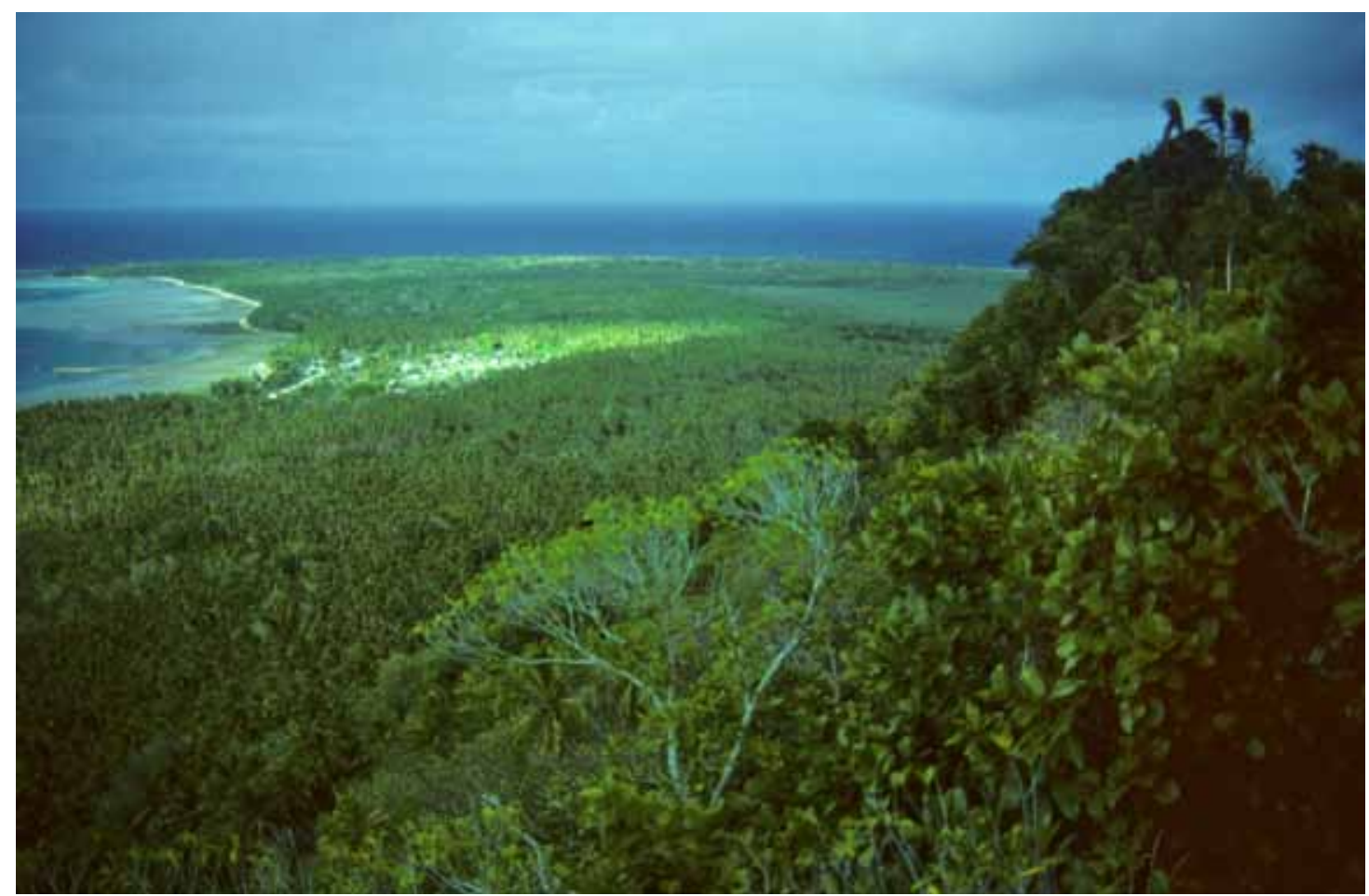

\section{FiguRE 7. Niuatoputapu.}

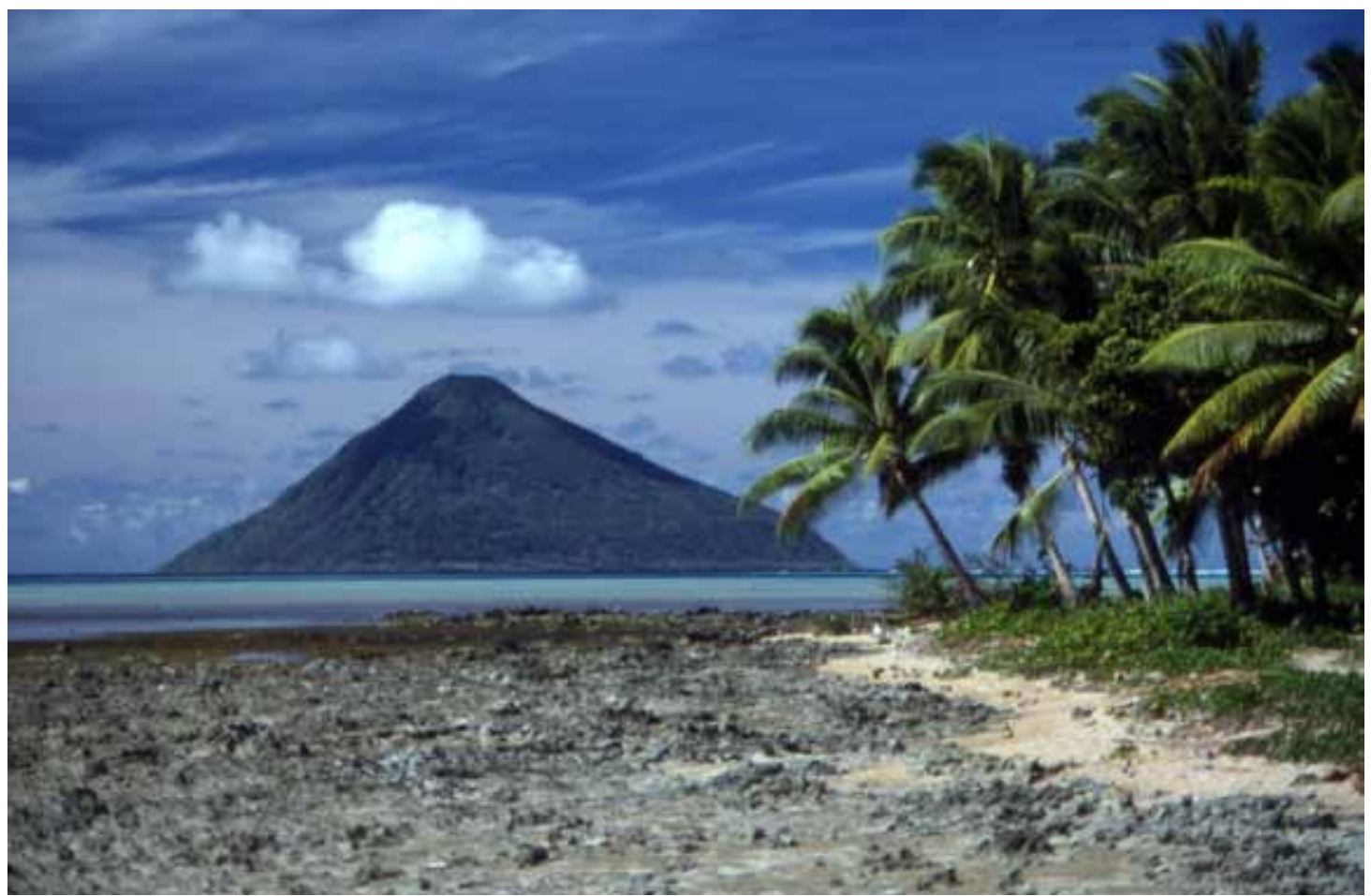

Figure 8. Tafahi. 


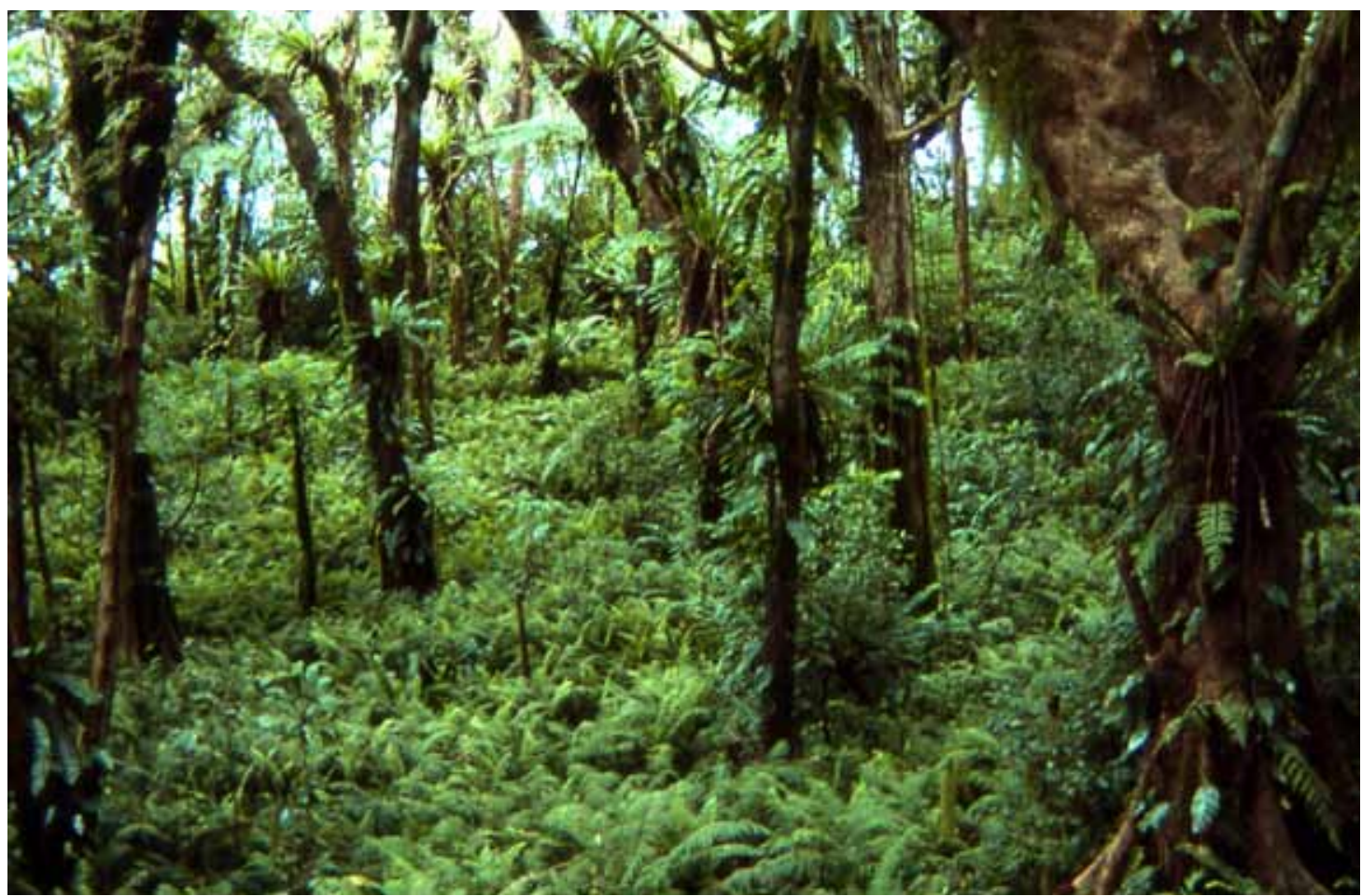

FIgURE 9. Cloud forest of Tafahi.

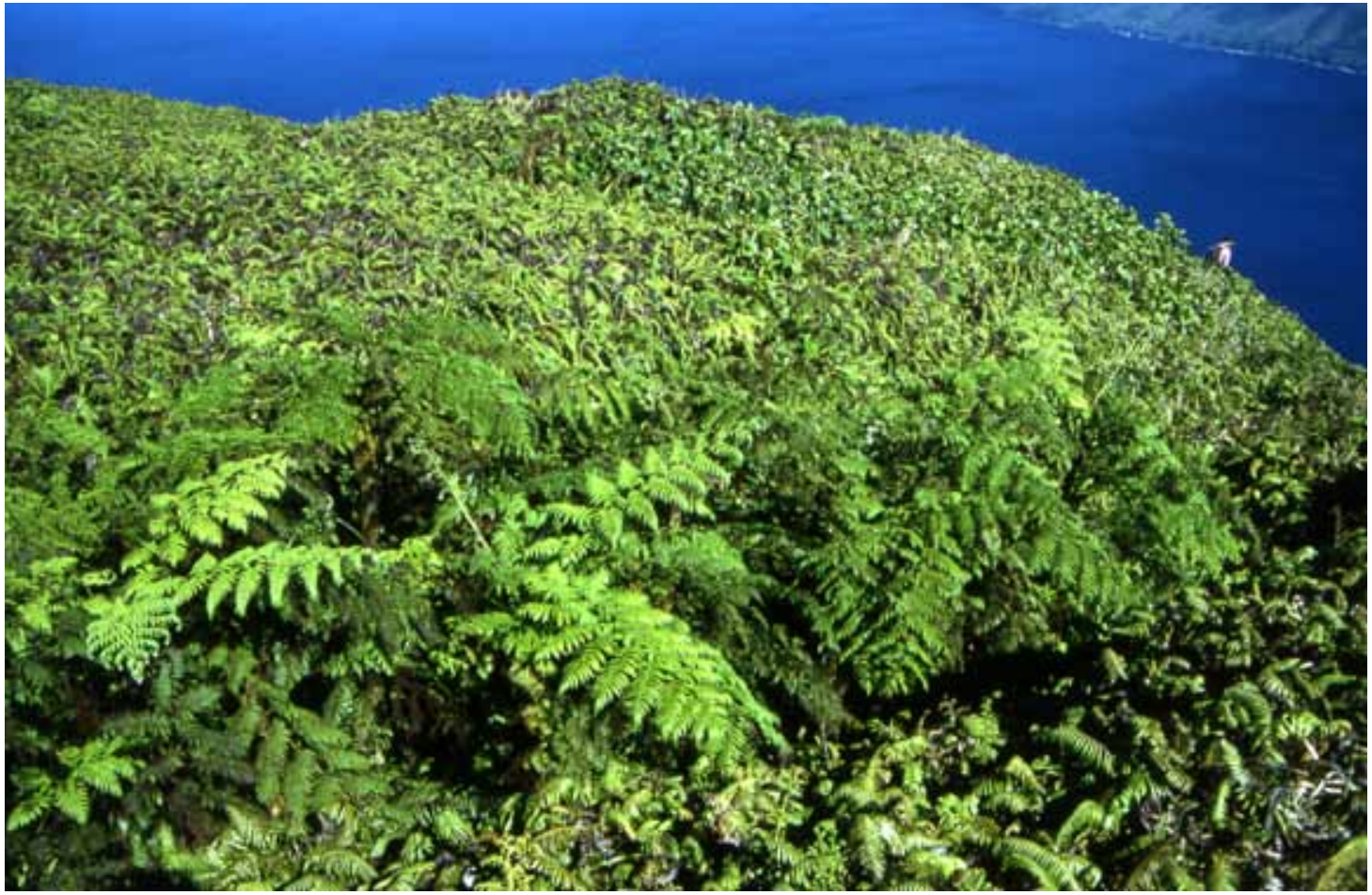

Figure 10. Fernland on Kao. 


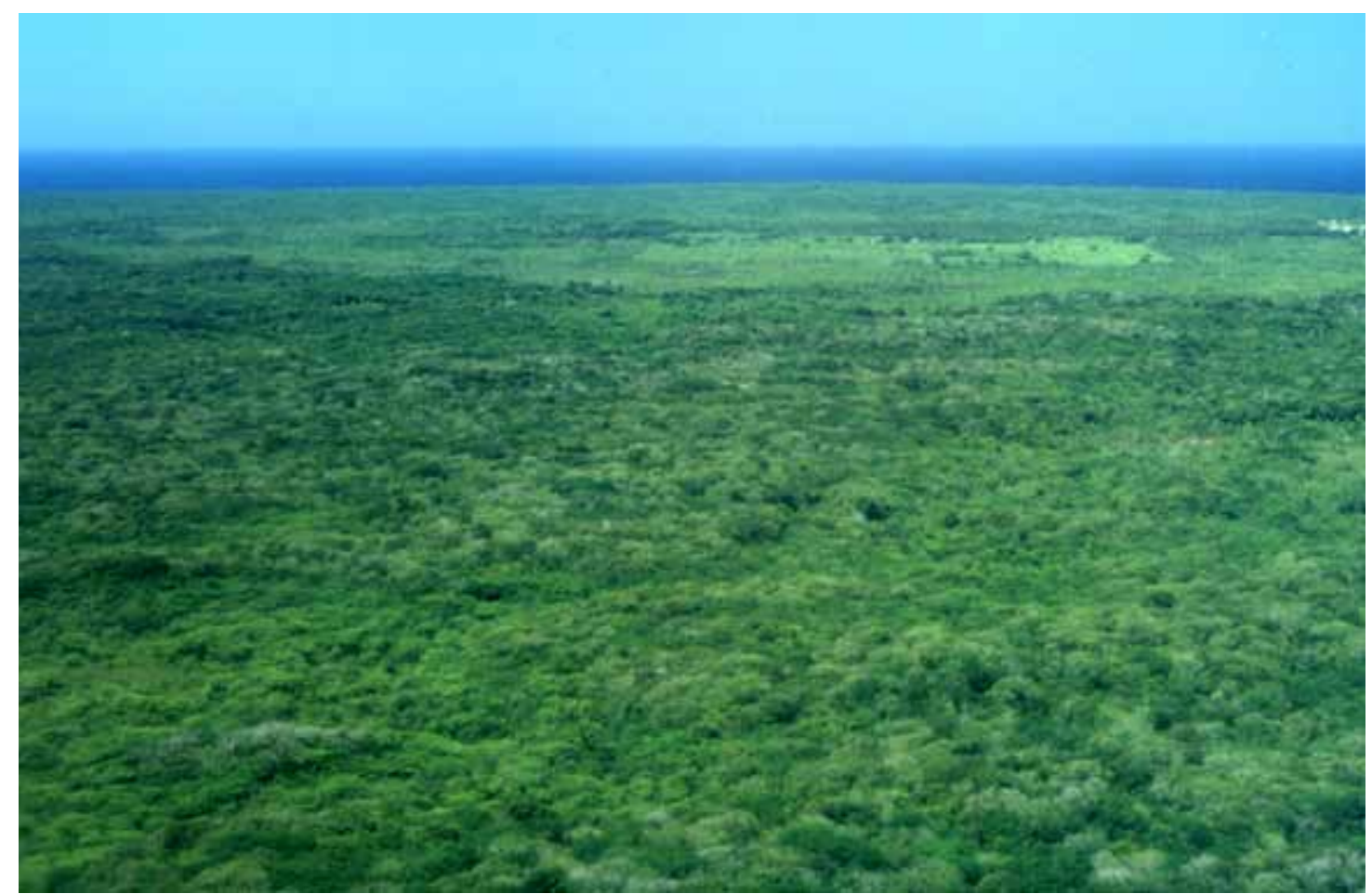

FIgURE 11. Niue.

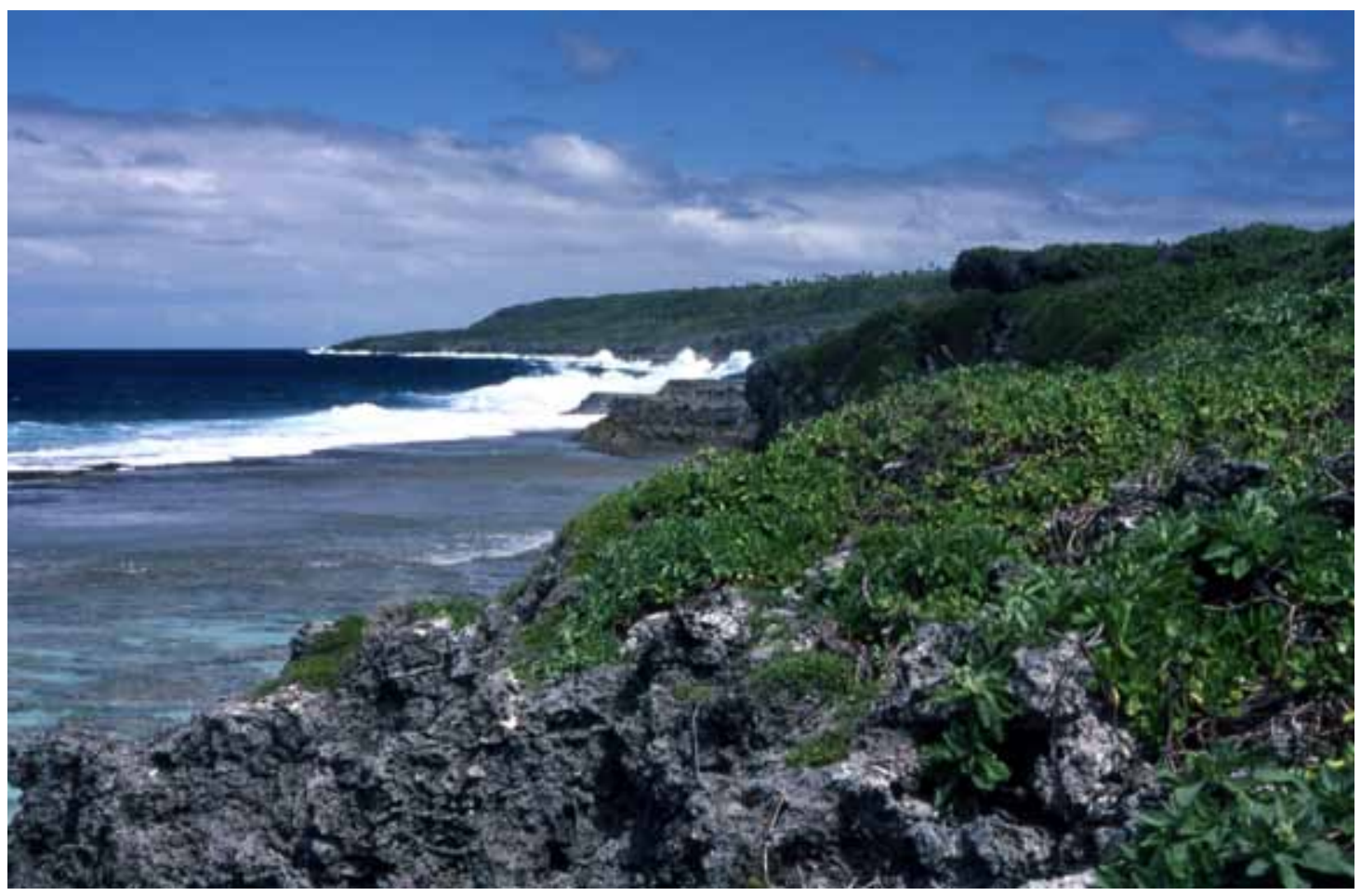

FIGURE 12. Niue coastal zone. 
during his work in Tonga (1984-present). Information from these collections and field work are the basis of a comparison of the vegetation of Tonga with that of Samoa (Whistler 1992), but little taxonomic work has been done on these specimens. His collections are stored at the University of Hawai'i, Manoa campus (HAW) and elsewhere. In addition to these large collections, relatively small collections by H. Hurlimann and P. Kirch were used as a basis for a checklist of the flora of Niuatoputapu published by H. St. John (1977).

Floristically, Tonga is part of the "Fijian Region" that extends from the Santa Cruz Islands and Vanuatu to Niue (Takhtajan 1969). Lying in the eastern portion of this region, Tonga has a smaller native flora than the Melanesian islands to the west, which lie closer to the Indo-Malaysian source area. The flora of Tonga is very similar to that of the adjacent islands and archipelagos, particularly Samoa. It is estimated to comprise 340 native angiosperm species, only $3 \%$ of which are thought to be endemic to the archipelago (Whistler 1992). A total of 44 orchid species (43 native and one introduced) are reported from Tonga, only one of which, Robiquetia tongaensis, is endemic there.

\section{Niue}

Niue (Fig. 11) lies in the South Pacific Ocean at a latitude of $19^{\circ} \mathrm{S}$ and a longitude of $169^{\circ} \mathrm{W}$, between Tonga to the west and the Cook Islands to the east (see Fig. 66). The flat, oval-shaped, limestone island, with an area of $260 \mathrm{~km}^{2}$ and a maximum elevation of $69 \mathrm{~m}$, was formed in recent geological times by the emergence and elevation of a coral atoll that sits atop a long-dormant undersea volcano. The outer portion or coastal zone (Fig. 12) of the island comprises several terraces formed during periods when the island paused during its emergence from the sea. This series of terraces is quite weathered in some areas and is marked in many places by deep crevices and rugged pinnacles. The central basin, which makes up the majority of the island, represents the former lagoon of the atoll. Its surface consists largely of jagged limestone, but some areas have a shallow layer of soil. Areas with deeper pockets of soil are favored by trees for the growth of dense lowland forests, but also by human inhabitants for the cultivation of food.

The climate in Niue is wet and tropical. The mean annual temperature is $25^{\circ} \mathrm{C}$, with a mean diurnal range of $8^{\circ} \mathrm{C}$. The mean maximum temperature ranges between 21 and $27^{\circ} \mathrm{C}$. Rainfall is relatively heavy with a mean annual total of $2040 \mathrm{~mm}$. The months from June to September are the driest, but even these months average at least $100 \mathrm{~mm}$ of precipitation. Humidity is nearly always high, averaging $89 \%$ at 9 a.m. Droughts occasionally occur, and cyclones periodically hit the island during the summer months (mostly November to April). The high rainfall and warm temperatures partly make up for the relatively poor soil conditions and allow the island (the central basin at least) to support a tropical rainforest and flora.

The Vegetation. Brief accounts of the vegetation were given by Frost and Berryman (1966), a timber survey by the Niue Forestry Section (1990), and Sykes (1970). Frost and Berryman divided the forest into three categories, "coastal forest," "light and scattered forest," and "merchantable forest," but did not discuss non-forest vegetation. The Forestry Section report also did not deal with overall vegetation, but reiterated the three forest types of Frost and Berryman and added a fourth vegetation category, "open areas." Sykes (1970) gave a brief account of the vegetation and noted that the island was originally covered with a rainforest of tall trees that formed a relatively dense canopy, below which was a relatively poorly developed shrub and herbaceous layer (Fig. 13). Because of the long period of human habitation and the modifications made during shifting agriculture, and, in more 
recent times, by a timber industry, most of the mature forest has now been removed and replaced by secondary forest in various stages of development. This secondary forest, according to Sykes, is generally richer in species numbers than the mature forest. In addition to the forest types, Sykes also recognized "scrub" areas that are the extreme result of man's activity. This vegetation, referred to by Yuncker (1943) as "thickets" and by Wright and van Westerndorp (1965) as "desert," are typically dominated by the fern Nephrolepis hirsutula. A comprehensive description of the vegetation of the island is found in Mueller-Dombois and Fosberg (1998).

The Flora. The documentation of the flora of Niue began in 1774 with the visit of Captain James Cook. However, only four specimens were obtained (Sykes 1970). Another collection was made in 1876 by amateur botanist F. Jensen, but his specimens, which are stored at the Natural History Museum (BM), were only noted in recent times (St. John 1976) and it is likely that many of the specimens attributed to Niue were actually collected elsewhere (Whistler 1984). The next significant collection was made in about 1899 by H.F. Moore, but these specimens, which are at the Smithsonian, have apparently not been studied. Two years later another collection was made by S.P. Smith (Smith 1902), and is now at the herbarium of the Auckland War Memorial Museum (AK).

It was not until 1940 that a large and comprehensive collection of the flora of Niue was made. This was by T.G. Yuncker, who, on the basis of these collections, published The Flora of Niue Island in 1943. Another larger collection was made by W.R. Sykes in 1965, and is the basis for his Contributions to the Flora of Niue (Sykes 1970). Several years later Sykes made further collections on Niue, but these specimens have not been documented. The present co-author (Whistler) made a small collection on Niue during two trips in the mid-1980s and during field work in 1997, but these too have not yet been documented. They are stored at the University of Hawai' $i$.

Like Tonga, Niue is floristically part of the "Fijian Region" that extends from the Santa Cruz Islands and Vanuatu to Niue (Takhtajan 1969). Lying at the eastern limit of this region, Niue has a smaller native flora than the Melanesian and Polynesian islands to the west, which lie closer to the Indo-Malaysian source region. Sykes estimated the size of the native vascular plant flora (flowering plants, ferns, and fern allies) at 175 species. Also present and listed by Sykes were a number of adventive or weedy species. In addition to the native species estimated by Sykes, several others were first recorded during a study by Whistler and Atherton (1997). A total of 17 species of native orchids are reported from Niue, none of them endemic to the island.

\section{The Cook Islands}

The Cook Islands are situated in the center of Polynesia east of Niue and nearly midway between Tahiti and Samoa, between $8^{\circ}$ and $23^{\circ} \mathrm{S}$ and $156^{\circ}$ and $167^{\circ} \mathrm{W}$. (See Fig. 66.) The archipelago comprises twelve inhabited and three uninhabited islands. These islands fall geographically into two groups - the Southern Cooks and the Northern Cooks. The Southern Cooks, which are a westward extension of the Austral Islands, comprise the high islands of Rarotonga, Mangaia, Atiu, Ma'uke, Miti'aro, and Aitutaki, and the low coral islands of Palmerston, Takutea, and Manuae; the Northern Cooks comprise the low coral islands of Pukapuka, Nassau, Manihiki, Rakahanga, Penrhyn (Tongareva), and Suwarrow. The total area of the archipelago is $240 \mathrm{~km}^{2}$, with the highest elevation of $652 \mathrm{~m}$ on Rarotonga (Fig. 14), which, with an area of $64 \mathrm{~km}^{2}$, is the largest and only mountainous island in the archipelago. Aitutaki, to the north of Rarotonga, is a classic example of an "almost atoll," with a small high island surrounded by a large lagoon. Mangaia and Ngaputoru (the 


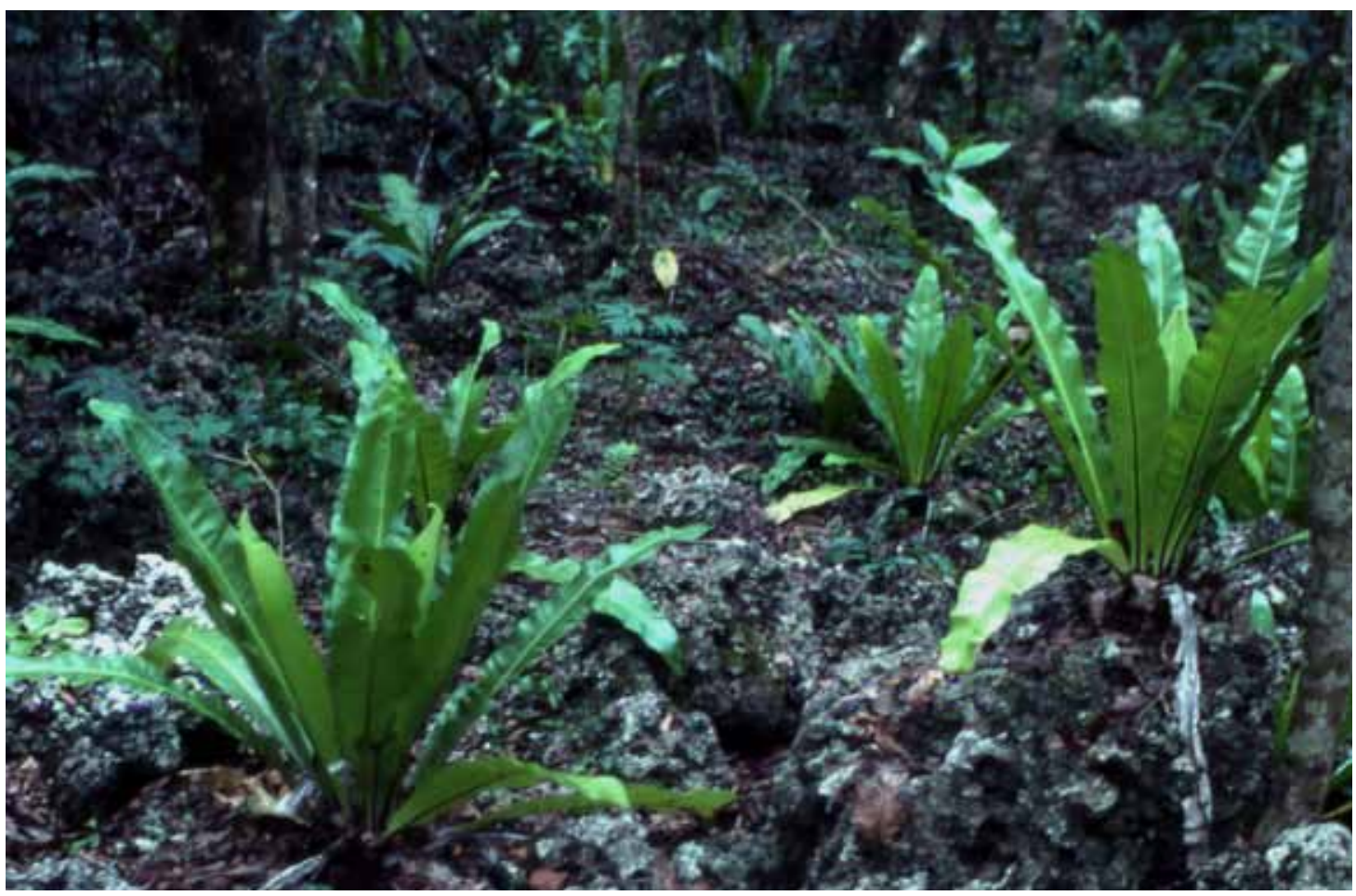

FIGURE 13. Inside Niue forest.
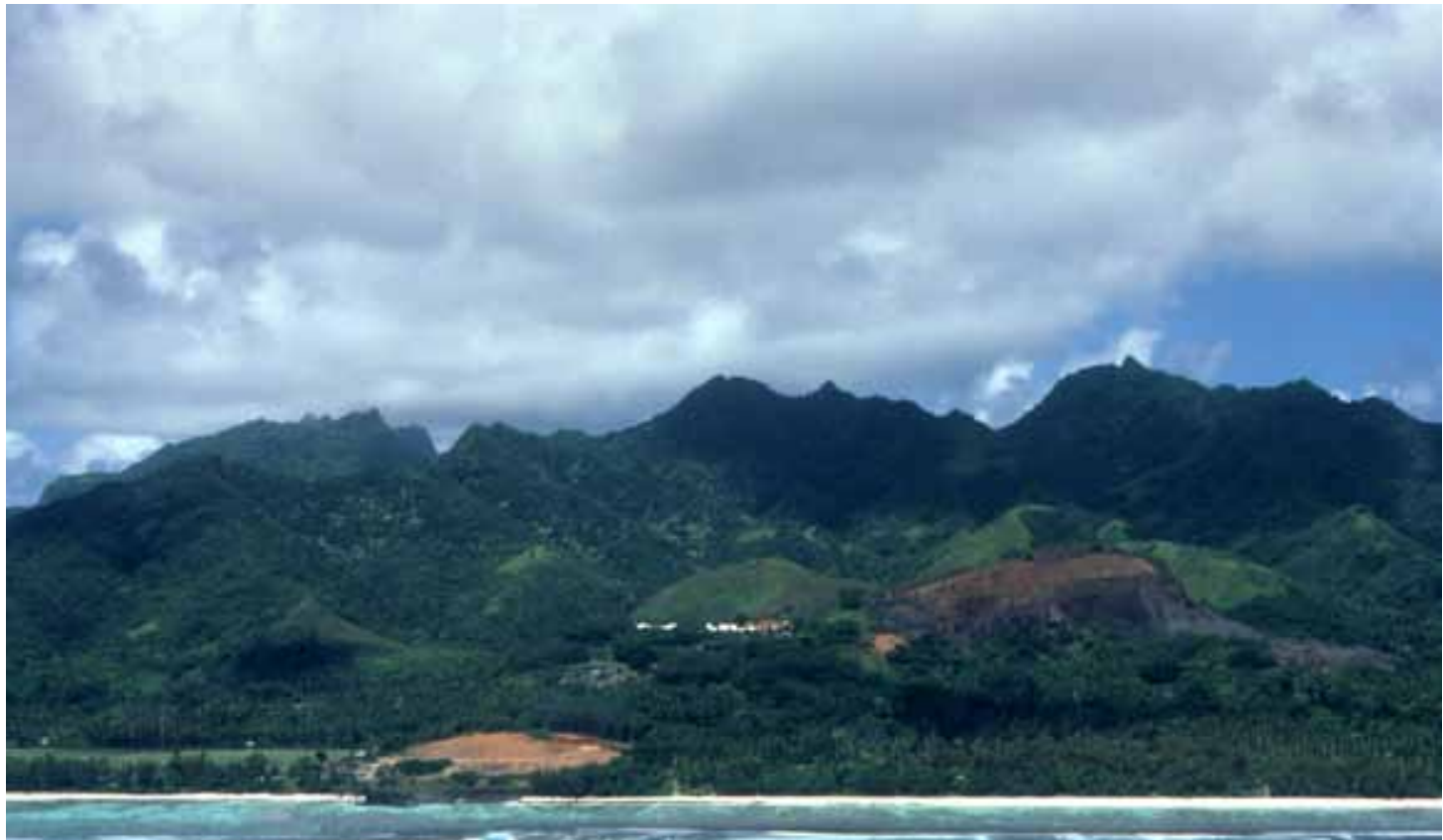

FIGURE 14. Rarotonga. 


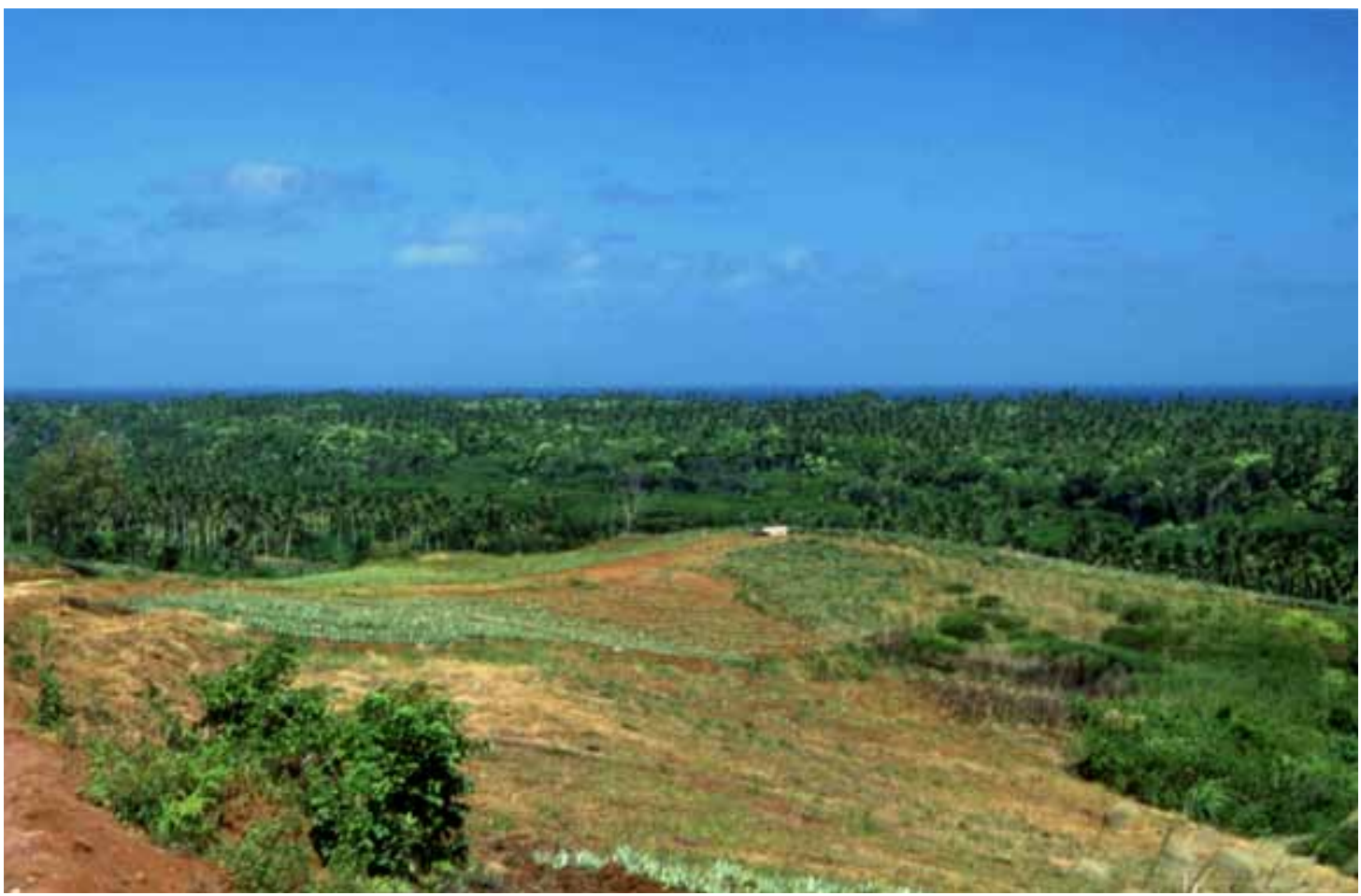

\section{Figure 15. Mangaia.}

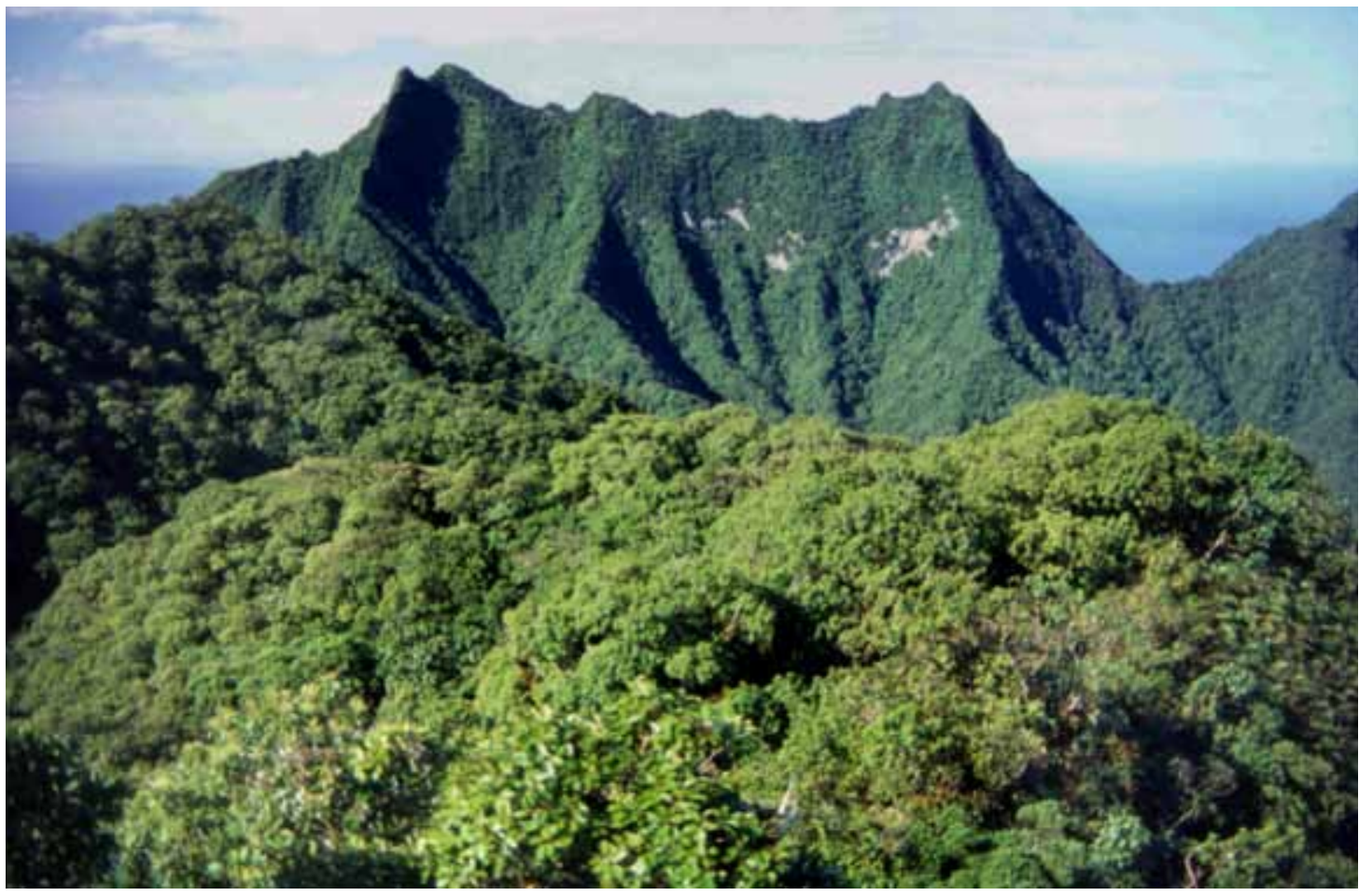

FIGURE 16. Rarotonga interior. 
collective name for Atiu, Ma'uke, and Miti'aro) are typical "makatea" islands comprised of uplifted limestone, except that the center (Fig. 15) is a highly eroded volcanic core.

The climate of the Cook Islands is warm and sunny all year round. The rainfall is moderate to heavy throughout the year, with November to March being particularly wet, and June to September being the driest period. On the main island of Rarotonga, the average annual precipitation is 2060 $\mathrm{mm}$, with the highest rainfall in the mountainous interior and the lowest on the coast on the leeward (northwest) side of the island. The average yearly temperature on Rarotonga is $24^{\circ} \mathrm{C}$, with an average low of $21^{\circ} \mathrm{C}$ and an average high of $27^{\circ} \mathrm{C}$. Aitutaki and the Northern Cooks are noticeably warmer than Rarotonga. Droughts occasionally occur, and cyclones periodically hit the islands during the warm season (mostly November to April).

The Vegetation. The first quantitative study of the vegetation of the Cook Islands was carried out by M.D. Merlin (1985). He divided the upland forest vegetation of Rarotonga (Fig. 16) into a "Homalium montane slope forest" dominated by Homalium acuminatum, "a Fagraea-Fitchia ridge forest" dominated by Fagraea berteroana and Fitchia speciosa, and a "Metrosideros cloud forest" dominated by Metrosideros collina. The lowland and littoral forest has been almost entirely removed and replaced by villages and plantations, and the slopes leading up to the peaks are covered with a fern community dominated by false-staghorn fern (Dicranopteris linearis).

Merlin undertook a similar quantitative survey on the limestone areas of the "makatea" island of Mangaia (Merlin 1991), the second largest of the Cook Islands. He recognized four vegetation types: a mixed native forest dominated by Elaeocarpus floridanus, a disturbed mixed native forest dominated by Hernandia moerenhoutiana or coconuts, a Pandanus scrub dominated by Pandanus tectorius, and a Barringtonia forest dominated by Barringtonia asiatica. The inland volcanic areas of the island were highly disturbed by agriculture, and little native vegetation and few native plant species can be found there now. Three of the other islands of the archipelago-Miti'aro, Ma'uke, and Atiu - have a similar vegetation of native forest on a raised limestone reef surrounding a highly disturbed central volcanic part. A comparison of vegetation of these three islands and of Mangaia was made by Franklin and Merlin (1992). A qualitative study of the littoral vegetation of the reef islands on the southeast side of Rarotonga was made by Stoddart (1972), who also did similar studies of the reef islands of Aitutaki (Stoddart 1975A) and of the main island of Aitutaki (Stoddart 1975B). A comprehensive description of the vegetation of the archipelago is found in Mueller-Dombois and Fosberg (1998).

The Flora. The first significant collection of the flora of the Cook Islands was made by T.G. Cheeseman in 1899, who reported in a flora of Rarotonga (Cheeseman 1903) that only seven specimens had been collected there in the previous 80 years since Europeans first inhabited the islands. Cheeseman collected only on Rarotonga, since transportation to the outer islands was difficult at that time. His specimens are stored at Kew and Auckland. Several decades later, a second flora of Rarotonga was published (Wilder 1931), based upon collections made on the island from 1925 to 1929. Wilder's specimens are at the Bishop Museum. Thus, prior to the last 30 years, very few collections were made from the other islands. Since that time major collections have been made from the outer islands (and Rarotonga) by W.R. Sykes and by the present coauthor (Whistler), but these have not been documented in the literature. Sykes' specimens are mostly at Christchurch, and Whistler's are mostly at the National Tropical Botanical Garden (PTBG) and the Bishop Museum, both in Hawai'i. 
The flora of the Cook Islands is believed to total about 190 native species of flowering plants (Sykes, pers. comm.). Like Niue and Tonga to the west, the affinities of its flora are IndoMalaysian. However, there is also a tropical American element best exemplified by Fitchia speciosa (Asteraceae). The rate of endemism is about $10 \%$. A total of 13 species of native orchids are reported from the archipelago, 12 of these occurring on Rarotonga and 6 on the outer islands. Only one of these, Habenaria amplifolia, is endemic to the archipelago (Rarotonga). The flora is currently being studied by W.R. Sykes, and the final number of species and rate of endemism awaits his publication. 


\section{THE ORCHIDS}

Although the orchid floras of Tonga, Niue, and the Cook Islands are not rich, they are diverse. Altogether, 52 species in 28 genera are included in this field guide. Given the sporadic occurrence of orchids and their favored habitats as forest floor terrestrials or canopy epiphytes, we anticipate that more species will be added to the flora in the future. If you find something that does not key out in this guide, the authors would be very interested to hear from you. You may well have found a novelty.

Previous Treatments. Yuncker (1959) provided a list of the orchids of Tonga that included 20 species in 15 genera. Yuncker (1943) and Sykes (1970) have provided records of Niue orchids, the former listing 13 species in 10 genera, the latter 18 species in 16 genera. Both included the introduced Vanilla planifolia (as $V$. fragrans and $V$. mexicana, respectively). Hallé et al. (1998) listed six species in five genera for Rarotonga. In the present account, 43 species in 25 genera are recognized for Tonga, 11 genera being new to the archipelago (since Yuncker 1959). Seventeen native species in 15 genera are reported from Niue, and 13 species in 11 genera from the Cook Islands. In an orchid flora of the Austral Islands, which are a southeastern extension of the Cook Islands, Hallé (1980) listed 11 native species, 8 of which are treated in the present publication. The introduced vanilla orchid (Vanilla planifolia) is reported from all four island groups. A total of 51 native species in 27 genera are included in this book, plus the introduced vanilla orchid.

Affinities and Origin of the Orchids. The orchids of our region have strong affinities with those of the neighboring archipelagos, which, in turn, have close affinities with the orchids of the Malay Archipelago, especially New Guinea. Most of the orchids of our region are found elsewhere in the Pacific, mostly in adjacent archipelagos such as Samoa, Fiji, or New Caledonia. Others are yet more widespread: Calanthe triplicata has a distribution that extends from Madagascar through S.E. Asia and the Malay Archipelago to N.E. Australia and the S.W. Pacific islands; Corymborkis veratrifolia, Eulophia spectabilis, and Geodorum densiflorum are found from the Asian mainland and the Malay Archipelago to N.E. Australia and the S.W. Pacific islands; and Taeniophyllum fasciola, a minute epiphytic orchid, is found throughout the tropical Pacific as far east as Pitcairn Island. Only one species in Tonga (Robiquetia tongaensis) and one in the Cook Islands (Habenaria amplifolia) are endemic to their respective islands. Niue has no endemic species.

Why are the species of the Pacific islands so widespread? The answer lies in their peculiar biology. All orchids have small, light seeds devoid of any endosperm, and comprise an embryo of just over 100 cells covered by a seed coat that is more or less waterproof. The seed pods of orchids can contain hundreds or even thousands of seeds. In windy places favored by orchids, the light ripe seeds can be blown long distances from the mother plant. When they arrive at a new locality, the seed can germinate if it meets the right fungus, one that has mycorrhizal properties. Such fungi have hyphae (fungal threads) that enter the orchid embryo, but the orchid cells can extract nutrients from the fungus as the embryo begins to germinate and grow. A body called a protocorm is produced when the embryo successfully germinates. Roots, a shoot, and leaves are produced from this so that eventually the orchid can photosynthesize and grow into a mature plant. Many orchids use common fungi to germinate and they, having light spores, are also widespread. Thus, orchid seeds reaching remote islands, even volcanic ones, have a chance of growing and flowering. It is no coincidence that many island orchids are self-pollinating and can produce seed without the presence of their natural pollinating insect. This is true of the orchids of our region. 


\section{WHAT IS AN ORCHID?}

The orchids found in Tonga, Niue, and the Cook Islands are a diverse group. The smallest one to be found there is the tiny Taeniophyllum fasciola, which is scarcely 2 or $3 \mathrm{~cm}$ in height with flowers 1-2 mm across, whereas the terrestrial Corymborkis veratrifolia may reach a meter or more in height, with flowers several cm long. Taeniophyllum and Didymoplexis micradenia have no leaves, but most other orchids have green leaves of various shapes and sizes. Some orchids (referred to as terrestrial) live on the ground while others grow perched on trees (epiphytes) or rocks (lithophytes). The introduced vanilla is a liana that can climb many meters up forest trees, using its roots for support. What then unites these diverse plants into the family called the Orchidaceae? The distinctive features of orchids that separate them from other flowering plants lie primarily in their flowers.

The plant. The vegetative features of orchids are, if anything, more variable than their floral ones. This is scarcely surprising when the variety of habitats in which orchids are found is considered. Tropical orchids grow in almost every situation: on the permanently moist floor of the lowland tropical rain forest; on the uppermost branches of tall forest trees where heavy rainfall is followed by scorching sun for hours on end; on rocks; and in grassy areas found on landslips and roadsides. The major adaptations seen in orchid vegetative morphology allow them to withstand adverse environmental conditions, particularly the problems of water conservation on a daily and seasonal basis.

That tropical orchids might suffer from periodic water deficits is not immediately obvious. However, rainfall is not continuous; even the wettest habitats and the rainfall patterns are markedly seasonal in many places in the tropics. Furthermore, most tropical orchids are epiphytic, growing on the trunks, branches, and twigs of trees, or as lithophytes on rocks. In these situations, water run-off is rapid and the orchids can dry quickly in the sunshine that follows the rain. Many orchids have marked adaptations of one or more organs that allow them to survive these periodic droughts. Some of these adaptations are as dramatic as those encountered in the cactus family Cactaceae. The stem can develop into a water-storage organ. This is so common in tropical orchids that the resulting structure has been given a technical name, a pseudobulb. Pseudobulbs comprise several internodes in the genus Dendrobium, while in Bulbophyllum they comprise one internode only. Pseudobulbs are also found in many terrestrial orchids and can grow either above the ground, as in Calanthe, or underground, as in Geodorum.

A few terrestrial orchids, such as Habenaria and Peristylus, lack pseudobulbs, but have underground tubers that enable the plant to survive drought. In suitable conditions the new growth occurs from one end of the tuber. In other orchids, such as Zeuxine and Goodyera, the stems are succulent but not swollen. The horizontal stem or rhizome creeps along the ground in the leaf litter, and erect shoots bearing the leaves are sent up periodically.

The leaf is another organ that has undergone dramatic modification in orchids. Fleshy or leathery leaves with restricted stomata, such as those of Dendrobium and Bulbophyllum species, are common. In Taeniophyllum the leaves have been reduced to scales, and photosynthesis takes place in the flattened green roots. Only one island orchid, Didymoplexis micradenia, is leafless and lacks chlorophyll altogether; it is termed saprophytic. Lacking chlorophyll, it cannot photosynthesize its own food and must obtain all of its nutrition from the mycorrhizal fungus with which it is associated.

Orchid species with green leaves used for photosynthesis are termed autotrophic. The terrestrial species usually have much thinner-textured leaves than their epiphytic cousins. In lowland forest, the perpetually moist atmosphere and lack of direct sunlight means that such leaves are not subject 
to drought. Some of the terrestrial species of the forest floor have beautifully marked leaves. In Goodyera, Zeuxine, Erythrodes, and their relatives, the leaves can range from green to deep purple or black and may be mottled or reticulate-veined with silver.

The roots themselves are highly modified in most epiphytic orchids. They provide both attachment to the substrate and also absorb water and nutrients in a periodically dry environment. The roots have an actively growing tip; the older parts are covered by an envelope of dead empty cells called a velamen. The velamen protects the inner conductive tissue of the roots and may also aid in the uptake of moisture from the atmosphere, acting almost like blotting paper for the orchid.

Life in the tropics can be inhospitable even for orchids. In those regions with a more marked seasonality, conditions may be very inhospitable for orchids at certain times of the year. Even tropical forests can have periods of relative drought, during which the orchids have to survive days or even weeks without rain. In these conditions, tropical orchids without water-storage capabilities in their stems or leaves can drop their leaves and survive on the moisture stored in their roots that are protected by their cover of velamen.

The inflorescence. Orchids bear their flowers in a variety of ways. Even within the same genus, different species have different ways of presenting the flowers. Most orchids in the Pacific islands have inflorescences bearing two or more flowers, usually borne on a more or less elongate floral axis comprising a stalk called the peduncle and a portion bearing the flowers called the rachis. In Phaius tankervilleae, the flowers are borne in an erect, elongate, unbranched raceme with the flowers arranged in a lax spiral around the rachis. Its individual flowers are attached to the floral axis by a stalk called the pedicel. In some species, such as Peristylus tradescantifolius, pedicels are virtually absent and the flowers are sessile on the axis; such an inflorescence is termed a spike.

Some interesting variations on the multi-flowered inflorescence occur in the genus Bulbophyllum. In several species, all the flowers are borne facing the same side of the rachis, this being called a secund inflorescence. The most spectacular group, however, comprises species in which the rachis is so contracted that the flowers all appear to come from the top of the flower stalk in an umbel, with the inflorescence somewhat resembling the head of a daisy. These bulbophyllums, such as Bulbophyllum longifolium, were for this reason formerly considered to be in the separate genus Cirrhopetalum. Compound inflorescences with many flowers are uncommon in island orchids, but those that are branched are termed panicles. In many species the flowers are borne one-at-a-time either sessile or on a short or long peduncle. Solitary flowers can be found in many genera, such as Bulbophyllum.

The flower. Orchid flowers are simple in structure and yet highly modified from the more typical monocotyledon flower exemplified by a Trillium or Lilium, to which orchids are very distantly allied. Monocots characteristically have their floral parts arranged in threes or multiples of three, and orchids are no exception. This can most easily be seen in the two outer whorls of the flower. For example, the common Pacific island orchid Phaius tankervilleae is similar in general floral structure to the majority of orchids from these islands. Its floral parts are situated at the apex of the ovary that is tripartite in cross section. The outermost whorl of the flower, the calyx, consists of three sepals that are petal-like and colored yellow with a red stripe in the middle. The two lateral sepals differ slightly from the third, which is called the dorsal or median sepal. In some orchids, such as dendrobiums and bulbophyllums, the lateral sepals form a more or less conical chin called a mentum at the base. 
The corolla of Phaius tankervilleae comprises three petals that are brightly colored. The two lateral petals, resembling the dorsal sepal in coloration and shape, are uppermost in the flower and differ markedly from the third petal, which lies at the bottom of the flower. This third petal, called the lip (or labellum), is highly modified, 3-lobed, and bears a short spur or nectary at the base. The spur can be longer or more saccate in other orchids and can contain callosities (ridges or keels) that are diagnostic for some species. The upper surface of the lip in some orchids may be adorned with a callus of raised ridges, lamellae, tufts, or areas of hairs or glands. The lip is an important adaptation of the orchid in facilitating cross pollination. It can be imagined as a brightly colored flag to attract potential and specific pollinators that are then guided towards the pollen and stigmatic surface by the form of the callus. The lip, therefore, can be supposed to act as a landing platform, and the callus structure as a guidance system for the pollinator.

The central part of the orchid flower shows the greatest modifications to the basic monocotyledon pattern. The major evolutionary forces at work in orchids have been the reduction in the number of floral parts and the fusion of the male and female organs into a single structure. The fused organ in the center of an orchid flower is called the column. In Phaius tankervilleae and in most Pacific island orchids, a single anther lies at the apex of the column. The pollen in the anther is not powdery as in most plants, but is borne in eight discrete masses called pollinia (single, pollinium). The pollinia are attached to a sticky mass called the viscidium (plural, viscidia). In other species the number of pollinia may be two, four, or rarely six, and these are attached to the viscidium either directly or by a stalk called a stipe in most epiphytic orchids, and a caudicle in most terrestrial ones.

The stigma, the receptive surface on which pollen alights and germinates, is also positioned on the column in the center of the orchid flower, on its ventral surface. The stigma is a sticky, lobed depression situated below and behind the anther in most orchids, but in some terrestrial genera, such as Habenaria and Peristylus, the stigma is bilobed with the receptive surfaces at the apex of each lobe. In many species the pollen masses are transferred to the stigmatic surface by a modified lobe of the stigma called the rostellum. This is developed in Phaius tankervilleae as a projecting flap that catches the pollen masses as the pollinator passes beneath it on its way out of the flower.

An interesting feature of the development of most orchid flowers is the phenomenon of resupination. In bud, the lip lies uppermost in the flower, while the column lies lowermost. In species with a pendent inflorescence, the lip will, therefore, naturally lie lowermost in the flower when it opens. However, this would not be the case in the many species with erect inflorescences, such as Phaius tankervilleae. Here the opening of the flower would naturally lead to the lip assuming a place at the top of the flower above the column. In most species this is not the case, and the lip is lowermost in the flower. This position is achieved by means of a twisting (resupination) of the flower stalk or ovary through $180^{\circ}$ as the bud develops.

Conclusions. An understanding of the floral and vegetative structure of orchids provides the clues needed to identify orchids. Knowledge of their floral morphology is critical for naming orchids because they are, for the most part, classified into genera and species on the finer details of the structure of their sepals, petals, lip, and column. Floral dissections provide the essential information for identification. For most species the shape of the sepals, petals, and especially the lip provides all of the information the reader needs. However, for the more critical taxa, details of the column, anther, pollinia, and rostellum may be needed before accurate identification is possible. The vegetative features also provide orchid growers with an idea of what to give their orchids to obtain optimal conditions for growth. If the seasonal nature of the growth found in many orchids is ignored, they will rapidly perish. 


\section{ORCHIDACEAE}

Herbs (or rarely scrambling vines), perennial, terrestrial, epiphytic, or lithophytic, autotrophic or rarely saprophytic, with rhizomes, tubers or rootstocks with mycorrhizal fungi in the roots. Stems either sympodial or less commonly monopodial, usually leafy, but leaves sometimes reduced to bract-like scales, one or more internodes at the base often swollen to form a "pseudobulb;" epiphytic species with aerial, assimilating adventitious roots, often bearing one or more layers of dead cells (velamen). Leaves 1-many, glabrous or very rarely hairy, entire in some cases except at the apex, alternate or occasionally opposite, often distichous, frequently fleshy or leathery, sometimes terete or canaliculate, almost always with a basal sheath that frequently sheathes the stem, sometimes articulated at the base of the lamina and sometimes with a false petiole. Inflorescence erect to pendent, spicate, racemose, or paniculate, one- to many-flowered, basal, lateral, or terminal, the flowers rarely secund, subumbellate, or distichously arranged. Flowers small to large, often quite showy, hermaphroditic (or rarely monoecious and polymorphic outside the region), sessile or variously pedicellate, most often twisted through $180^{\circ}$, occasionally not twisted or twisted through $360^{\circ}$. Ovary inferior, unilocular and the placentation parietal (or rarely trilocular and the placentation axile). Sepals usually free but sometimes variously adnate, the median (dorsal) one often dissimilar to the laterals, the laterals sometimes adnate to a column-foot to form a saccate, conical, or spur-like mentum. Petals free or rarely partly adnate to sepals, similar to sepals or not, often showy. Lip entire, variously lobed or two- or three-partite, ornamented or not with calli, ridges, hair cushions, or crests, with or without a basal spur or nectary, margins entire to laciniate. Column short to long, with or without a basal foot, occasionally winged or with lobes or arms at apex or ventrally; anther one (or rarely two or three outside region), terminal or ventral on column, cap-like or opening by longitudinal slits; pollinia mealy, waxy or horny, sectile or not, $2,4,6$, or 8 , sessile or attached by stalks to one or two sticky viscidia; stigma 3-lobed, the midlobe often modified to form a rostellum, the other lobes either sunken on the ventral surface of the column behind the anther or with two lobes porrect. Fruit a capsule, usually opening laterally by 3 or 6 slits; seeds numerous, dust-like, lacking endosperm, rarely winged.

The orchids comprise one of the largest families of flowering plants, with an estimated 800 genera and 25,000 species, with some estimates suggesting as many as 30,000 species. They are distributed in all continents except for Antarctica, but are most numerous in the humid tropics and subtropics. Altogether, 28 genera of orchids are reported from Tonga, Niue, and the Cook Islands. Some 43 native species are found in Tonga, 30 being terrestrial, the remainder epiphytic. One epiphytic Tongan species is endemic (Robiquetia tongaensis). Seventeen native species have been found on Niue, nine of them terrestrial and the rest epiphytic. Thirteen native species are reported from the Cook Islands, eight of them terrestrial and five epiphytic; only one of them is endemic (Habenaria amplifolia). The affinities of the orchids are with those of other S.W. Pacific islands and New Guinea. Orchids are extensively grown around the world as ornamentals, but other economic uses are few. Two species of Vanilla are grown commercially in the Pacific islands, especially in the Society Islands, to produce the flavoring vanilla. One, Vanilla planifolia, has been introduced to Niue and the Cook Islands, where it has escaped into the wild.

The classification of the family is currently the subject of some debate, particularly the number of subfamilies that should be recognized and the placement of certain tribes, subtribes, and genera. The classification of Chase et al. (2003), elaborated in Pridgeon et al. (1999, 2001, 2003, 2005), which is strongly supported by recent molecular, embryological, and morphological analyses, is followed here. They recognize five subfamilies: Apostasioideae, Cypripedioideae, Vanilloideae, Orchidoideae, and Epidendroideae. Only the last three subfamilies are found in our region: Vanilloideae (genus 1), Orchidoideae (genera 2-9), and Epidendroideae (genera 10-28). 
In the species accounts, an exclamation mark after the herbarium designation letter indicates that the lead author has personally examined the specimen. A $\dagger$ after B (Berlin) indicates that the type was probably destroyed during World War II. 


\section{ARTIFICIAL KEY TO THE GENERA}

1. Orchids liana-like or vine-like

1. Vanilla

1. Orchids not as above

2. Stems leafless or apparently so at flowering time

3. Plants terrestrial; roots brown, underground

4. Leaves absent; stem buff-colored; plant saprophytic

12. Didymoplexis

4. Leaves present before flowering, green, photosynthetic

11. Nervilia

3. Plants epiphytic; roots greenish, photosynthetic, attached to tree bark

or hanging freely

24. Taeniophyllum

2. Stems not as above

3. Plants terrestrial

4. Plants with fleshy underground tubers or pseudobulbs either on or below the surface of the soil

5. Leaves solitary, heart-shaped or ovate

11. Nervilia

5. Leaves several, linear, lanceolate, or oblanceolate

6 . Inflorescence with apex recurved and facing towards ground

28. Geodorum

6. Inflorescence erect

7. Flowers small, arranged in a spiral; lip entire, porrect

7. Spiranthes

7. Flowers not obviously spirally arranged; lip 3-lobed, pendent

8. Plant with pseudobulbs; leaves $2-3$, borne at base or towards pseudobulb apex; sepals and petals $7-9 \mathrm{~mm}$ long

27. Eulophia

8. Plant with tubers; leaves 5-7, thin-textured, borne in middle or apical part of slender stem; sepals and petals variable

9. Sepals and petals less than $5 \mathrm{~mm}$ long; spur less than $8 \mathrm{~mm}$ long

8. Peristylus

9. Sepals and petals more than $10 \mathrm{~mm}$ long; spur more than

$25 \mathrm{~mm}$ long 9 .

9. Habenaria

4. Plants with a fleshy or woody underground, non-tuberous rhizome

5. Erect stems woody, growing from a woody rhizome; inflorescences lateral and terminal;

flowers more than $2 \mathrm{~cm}$ long; bracts not noticeably distichous

10. Corymborkis

5. Erect stems fleshy, growing from a fleshy creeping rhizome or pseudobulbous from

a creeping rhizome; inflorescences terminal; flowers less than $1 \mathrm{~cm}$ long; bracts noticeably distichous

6. Stems similar to creeping rhizome, fleshy but not swollen

7. Lip uppermost in flower.

4. Hetaeria

7. Lip lowermost in flower

8. Flower lip with a spur

9. Leaves dark green with a longitudinal white stripe; spur conical, entire or slightly bilobed at tip, with stalked two glands within

5. Vrydagzynea

9. Leaves green; spur cylindrical, bilobed at tip, with 2-4 sessile glands within

2. Erythrodes

8. Flower lip lacking a spur but often with a saccate base

9. Lip with papillae or glands in saccate basal part

3. Goodyera

9. Lip lacking glands within basal part

6. Zeuxine

6. Stems dissimilar from rhizome, often swollen and pseudobulbous

7. Inflorescences lateral, from base or sides of the pseudobulb or stem

8. Flowers urn-shaped

16. Acanthephippium

8. Flowers not urn-shaped 
9. Tepals pink or rose-purple, rarely white, never turning blue when bruised; lip lacking a spur; callus prominently bilobed between the narrowly oblong, erect side lobes

9. Tepals white, yellow or brown with a purple lip, turning blue when bruised; lip with a spur; callus not as described above

10. Column short, almost as broad as long, adnate to the base of the lip; lip deeply 3- or 4-lobed, more or less flat, with a basal callus 13. Calanthe 10. Column elongate, more or less free from lip; lip obscurely lobed, more or less tubular, lacking a basal callus

14. Phaius

7. Inflorescences terminal

8. Lip more or less as broad as long; erect, uppermost in the flower; column very short, not extending beyond the base of the lip

18. Crepidium

8. Lip broader than long, recurved or porrect, lowermost in flower; column elongate, incurved, at least half length of the lip

17. Liparis

3. Plants epiphytic or rarely lithophytic

4. Plants with bilaterally compressed, iridiform leaves; flowers less than $3 \mathrm{~mm}$ across, in dense cylindrical spike

19. Oberonia

4. Plants with dorsiventrally flattened or terete leaves; flowers larger, in lax to dense spikes or solitary

5. Plants sympodial, each growth determinate; inflorescences terminal and lateral

6. Pollinia 4

7. Inflorescence lateral

23. Bulbophyllum

7. Inflorescence terminal or axillary from upper nodes

22. Dendrobium

6. Pollinia 6 or 8

7. Stems elongate with well-spaced distichous leaves; inflorescences lateral; pollinia 6

20. Appendicula

7. Stems short with leaves borne more or less in a fan-shape; inflorescences borne amongst leaves; pollinia 8

21. Phreatia

5. Plants monopodial, each growth of indeterminate length; inflorescences lateral

6. Stems elongate; inflorescence more than $6 \mathrm{~cm}$ long; flowers pink or white

25. Robiquetia

6. Stems very short; inflorescence less than $6 \mathrm{~cm}$ long; flowers pale yellow.

26. Tuberolabium 


\title{
GENERIC AND SPECIES ACCOUNTS
}

\author{
1. VANILLA \\ Plum. ex Mill., Gard. Dict. Ed. 6. 1752.
}

Scrambling or climbing vines or lianas with thick adventitious roots emerging opposite the leaves, and fleshy, green, often branching stems leafy along their length. Leaves conduplicate, fleshy, well-developed and dorsi-ventrally flattened, or scale-like. Inflorescence lateral, short, densely few- to many-flowered; peduncle and rachis fleshy, green; bracts persistent or not, shorter than the pedicel and ovary. Flowers large, resupinate, fleshy, short-lived, often showy; pedicel and ovary green. Sepals and petals free, linear-lanceolate or linearoblanceolate, acute. Lip free or with margins fused to column sides, porrect, three-lobed, often obscurely so, more or less enclosing the column, lacking a spur, with a callus of hairs or lacerate flaps. Column slender, elongate, lacking a foot, often hairy on lower surface; pollinia four, mealy. Fruit a dehiscent capsule or slightly dehiscent berry, often strongly fragrant.

A genus of about 107 species widely distributed in the New and Old World tropics. Two species are cultivated in the Pacific islands, especially in the Society Islands, and are occasionally found as escapes. A single species is grown in Tonga, the Cook Islands, and Niue (and is one of the two cultivated species in the Society Islands), and is occasionally found as an escape.

Vanilla planifolia Andrews, Bot. Repos. 8: t. 538. 1808. Lectotype: cult. Greville (illustration cited here). For full synonymy, see Kores (1991).

Climbing vine or liana up to $15 \mathrm{~m}$ long. Stem circular in cross-section, 1-2 cm in diameter, green. Leaves oblong or oblong-elliptic, acute, $8-25 \times 2-8 \mathrm{~cm}$. Inflorescence lateral, densely many-flowered, 5-8 cm long. Flowers large, green, with a creamy-green lip. Sepals and petals linear-oblanceolate, 4-7 × 1-1.5 cm. Lip 3-lobed, 4-5 × 1.5-3 cm, with irregular dentate lateral margins; callus of several reflexed fimbriate plates in upper part of lip. Column 3-4 cm long, puberulous on lower surface. Fig. 17.

Distribution. Native to Mexico and Central America. Widely cultivated around the tropics. Introduced to Tonga (Vava'u), the Cook Islands (Sykes, pers. comm.), and Niue, where it is established in the wild.

НавітAт. Uncommon in lowland to montane forest, especially in secondary forest, and sometimes in gardens.

Collections. Vava'u: Whistler (sight record). Rarotonga: Sykes (sight record). Niue: Sykes CHR 150572; Yuncker 9856.

\section{ERYTHRODES}

Blume, Bijdr. Fl. Ned. Ind.: 410. 1825.

Physurus Rich., De Orchid. Eur.: 33 (1817) nom. nud.; Rich. ex Lindl., Gen. Sp. Orchid. Pl.: 501(1840).

Small to medium-sized terrestrial herbs with fleshy creeping rhizomes rooting at the nodes, and erect, leafy fertile shoots. Leaves not articulate, thin-textured. Inflorescence terminal, erect, racemose, manyflowered. Flowers small, not opening widely, resupinate. Dorsal sepal with the petals forming a hood over the column. Lateral sepals spreading. Petals entire, membranous, narrower than the sepals. Lip appressed to the column, entire or with a small apical recurved blade, prolonged at the base into a spur that projects 
between the lateral sepals; spur entire or bilobed, short to long, with 2-4 sessile calli within. Column short; anther erect; pollinia two, sectile, clavate, attached by caudicles to a small viscidium; rostellum short, bilobed.

A genus of about 100 species widespread in the tropics of the New World, tropical Asia, and the Pacific region, but absent from Africa. Two species are reported from Tonga.

\section{Key to Species}

1. Sepals $6-8 \mathrm{~mm}$ long, densely hairy; lip apex acute; leaves $5-10 \mathrm{~cm}$ long 1. E. oxyglossa

1. Sepals $2.5-4 \mathrm{~mm}$ long, glabrous or sparsely hairy on outer surface; lip apex a small ovate, obtuse blade; leaves $3-5.5 \mathrm{~cm}$ long 2. E. purpurascens

1. Erythrodes oxyglossa Schltr., Bot. Jahrb. Syst. 39: 53. 1906. Type: New Caledonia, Schlechter 15749 (holotype $\mathrm{B} \dagger$ ).

Erythrodes lilyana (H. Fleishm. \& Rech.) Schltr., Repert. Spec. Nov. Regni Veg. 9: 87. 1910.

Physurus lilyanus H. Fleischm. \& Rech., Denkschr. Kaiserl. Akad. Wiss., Wien. Math.-Naturwiss. K1. 85: 253, t. 1, fig. 3. 1910. Types: Samoa, Rechinger 63, 1515, 1590 (all syntypes W!).

Terrestrial herb $25-40 \mathrm{~cm}$ in height. Leaves obliquely oblong-lanceolate to oblong-ovate, acuminate, $5-10 \times 1.5-2.5 \mathrm{~cm}$; petiole slender, $2.5-3.3 \mathrm{~cm}$ long. Inflorescence $12-27 \mathrm{~cm}$ long, many-flowered; peduncle pubescent in upper part; rachis pubescent; bracts lanceolate, $8-10 \mathrm{~mm}$ long, hairy. Flowers dull brownish white, pubescent on the outside of the sepals. Sepals lanceolate, $6-8 \times 1.7-2.3 \mathrm{~mm}$, densely hairy. Petals obliquely oblanceolate, acute, 5.5-7.5 × 1.5-1.7 mm. Lip 6-8.5 mm long, lanceolate to oblong-lanceolate, acute; spur bilobed at apex, 2.5-3.5 mm long, with 2 small glands within. Column 2.5-3.5 mm long. Fig. 18.

Distribution. Tonga (Kao and Tofua). Also in New Caledonia, Fiji, and Samoa.

НАвітAт. Uncommon in foothill to montane forest on ridges of volcanic islands; 300 to ca. $1000 \mathrm{~m}$. Collections. Kao: Buelow 621, 3004, 3197. Tofua: Buelow 439; Whistler 10602.

2. Erythrodes purpurascens Schltr., K. Schum. \& Lauterb., Fl. Schutzgeb. Südsee, Nachtr.: 88. 1905. Type: Papua New Guinea, Paub, Schlechter 14616 (holotype B†).

Cheirostylis sp. sensu Yuncker, Bernice P. Bishop Mus. Bull. 184: 31. 1945.

Terrestrial herb up to $32 \mathrm{~cm}$ in height. Leaves obliquely ovate, acute, $3-5.5 \times 1.5-2.2 \mathrm{~cm}$. Inflorescence up to $28 \mathrm{~cm}$ long; bracts lanceolate, acuminate, 5-8 mm long. Flowers white within, brown on outside and with brown marks on lip, small, 4-6 mm long; pedicel and ovary 6-8 $\mathrm{mm}$ long, pubescent. Sepals elliptic-lanceolate, $2.5-4 \times$ ca. $1 \mathrm{~mm}$, glabrous or very sparsely pubescent on outer surface. Petals obliquely oblanceolate, acute, $2.5-3.5 \times 0.7-0.8 \mathrm{~mm}$. Lip subpandurate, $2.5-4.5 \mathrm{~mm}$ long, the apical lamina ovate, obtuse; spur 1.5-2.5 mm long, bilobed, usually with 2 small calli within. Column 2.5-3.5 mm long. Fig. 19.

Distribution. Tonga (Kao and Tofua). Also in New Guinea, Fiji, and Samoa.

НАвітAт. Uncommon among rocks and in small gullies in scrubby montane forest; 300-450 m.

Collections. Kao: Buelow 2940, 3005. Tofua: Buelow 469, 2541; Whistler 10603.

Note. We have assigned these collections to E. purpurascens rather than to E. parvula Kores because the latter lacks calli on the lip. 


\section{GOODYERA}

\section{R. Br., Aiton \& W.T.Aiton, Hortus Kew ed. 2, 5: 197. 1813.}

Terrestrial herbs with creeping fleshy rhizomes rooting at the nodes, and erect, fleshy, leafy fertile shoots. Leaves thin-textured to fleshy, not articulated. Inflorescence terminal, racemose, few- to many-flowered. Flowers small, resupinate, usually tubular but never opening widely. Dorsal sepal and petals connivent into a hood over the column. Lateral sepals porrect, reflexed or spreading somewhat. Lip parallel to column, entire, deeply saccate at the base, with numerous thread-like calli within. Column short to long; anther erect, persistent; pollinia two, sectile, clavate, often deeply divided, attached by caudicles to a rather large viscidium; rostellum long, bilobed.

A genus of about 40 species found in both temperate and tropical parts of the Old and New Worlds, but not in Africa. A single species is reported from Tonga.

Goodyera rubicunda (Blume) Lindl.,Edward's Bot. Reg. 25: 61, misc. 92. 1839. Type: Java, Blume s.n. (holotype L!, isotype P!).

Goodyera anomala Schltr., Repert. Spec. Nov. Regni Veg. 9: 86. 1910. Type: Samoa, Vaupel 405 (syntype $\mathrm{B} \dagger$ ).

Goodyera biflora sensu Kraenzl., Bot. Jarhb. Syst. 25: 600. 1898, non Hook. f.

Goodyera grandis (Blume) Blume, Fl. Javae ser. 2, 1, Orch.: 36. 1858.

Goodyera rubens Blume, Fl. Javae ser. 2, 1, Orch.: 36, t. 9. 1858)

Goodyera rubicunda (Blume) Lindl. var. triandra (Schltr.) N. Hallé, Fl. Nouv.-Caléd. 8: 532. 1977.

Goodyera triandra Schltr., Bull. Herb. Boissier II, 6: 298. 1906. Type: Vanuatu, Morrison s.n. (holotype $\mathrm{B} \uparrow$, isotype AMES!).

Goodyera waitziana sensu H. Fleischm. \& Rech., Denkschr. Kaiserl. Akad. Wiss., Wien. Math.Naturwiss. K1. 85: 254. 1910, non Blume.

Neottia grandis Blume, Bijdr. Fl. Ned. Ind.: 407. 1825.

Neottia rubicunda Blume, loc. cit.: 408. 1825.

Terrestrial herb up to $70 \mathrm{~cm}$ in height; rhizome creeping. Leaves obliquely elliptic to elliptic-lanceolate, acute or acuminate, $12-18 \times 3.5-6 \mathrm{~cm}$, long-petiolate, margins crisped-undulate. Inflorescence up to $40 \mathrm{~cm}$ long, pubescent. Flowers orangish, reddish brown or greenish pink, sometimes abnormal and triandrous. Sepals ovate or narrowly ovate, acute, $7-8.5 \times 2.5-4 \mathrm{~mm}$, densely pubescent. Petals clawed, obliquely ovate to subrhombic, acute, $7-7.5 \times 2.5-3 \mathrm{~mm}$. Lip entire, $6-7.5 \mathrm{~mm}$ long, saccate at base, recurved and ligulate at apex. Column 5-6.5 mm long. Fig. 20.

Distribution. Tonga ('Eua). Also from southern Ryukyu Islands and Malaya throughout Malesia to northern Australia and eastwards to the Solomon Islands, Vanuatu, Fiji, and Samoa.

НАВітAт. Uncommon in lowland and montane forest on volcanic soils; 250-300 m.

Collections. 'Eua: Buelow 2516; Hotta 5226, 5272; Hurlimann 260; Sykes 351, 412, 488; Whistler 6483, 12165; Wood 6846.

NotE. Plants with abnormal flowers having three anthers are sometimes found.

\section{HetAeria}

Blume, Bijdr. Fl. Ned. Ind.: 409. 1825.

Small to medium-sized terrestrial herbs with fleshy creeping rhizomes rooting at the nodes, and erect, leafy 
stems. Leaves simple, membranous, petiolate and sheathing at the base. Inflorescence terminal, racemose, fewto many-flowered, lax or dense. Flowers small, non-resupinate. Dorsal sepal entire, adnate to the membranous petals. Lateral sepals similar to the dorsal but oblique, enclosing the saccate lip-base. Lip more or less parallel to the column, entire, the base saccate, bearing two or more unstalked papillae or glands within, the apex small, concave, often contracted into a claw with a terminal, bilobed, transverse blade. Column short, with two parallel lamellae or keels on ventral surface; anther persistent, erect; pollinia two, sectile attached to a common viscidium; rostellum short, bilobed.

A genus of perhaps 70 species widespread from India throughout S.E. Asia and the Malay Archipelago to northern Australia and the S.W. Pacific islands. Also in Africa and Madagascar, and possibly the New World tropics. Two species are reported from Tonga, one of them also in Niue.

\section{Key to Species}

1. Leaves elliptic to ovate-elliptic, $4-12 \mathrm{~cm}$ long, $2-4.5 \mathrm{~cm}$ wide; lip apex very small, not expanded into a transverse blade

1. Leaves narrowly elliptic to lanceolate, $10-22 \mathrm{~cm}$ long, $0.7-2.2 \mathrm{~cm}$ wide; lip apex expanded into a transversely bilobed blade

1. H. oblongifolia

2. H. whitmeei

1. Hetaeria oblongifolia Blume, Bijdr. Fl. Ned. Ind.: 410. 1825. Type: Java, Blume s.n. (holotype L!). Aetheria oblongifolia (Blume) Lind1., Gen. Sp. Orchid. P1.: 491. 1840.

Goodyera discoidea (Rchb. f.) Schltr., Bot. Jahrb. Syst. 39: 57. 1906.

Hetaeria discoidea (Rchb. f.) Schltr., Repert. Spec. Nov. Regni Veg. 9: 89, in obs. 1910.

Hetaeria forcipata Rchb. f., Linnaea 41: 62. 1877. Type: Fiji, Roezl s.n. (holotype W!).

Hetaeria raymundii Schltr., Bot. Jahrb. Syst. 56: 453. 1921. Type: Palau Islands, Raymundus s.n. (holotype $\mathrm{B} \dagger$ ).

Hetaeria samoensis Rolfe, Bull. Misc. Inform. Kew 1898: 199. 1898. Type: Samoa, Walter s.n. (holotype CAM!, isotype $\mathrm{K}$ !).

Hetaeria similis Schltr., Repert. Spec. Nov. Regni Veg. 9: 88. 1910. Type: Samoa, Vaupel 657 (holotype B†, isotypes BISH!, K!).

Rhamphidia discoidea Rchb. f., Linnaea 41: 59. 1877. Type: New Caledonia, Vieillard 1311 (holotype P!, isotype BM!).

Rhamphidia tenuis sensu H. Fleischm. \& Rech., Denkschr. Kaiserl. Akad. Wiss., Wien. Math.Naturwiss. K1. 85: 254. 1910, non Lindl.

Terrestrial herb up to $50 \mathrm{~cm}$ in height. Leaves obliquely elliptic to ovate-elliptic, acute or abruptly acuminate, 4-12 × 2-4.5 cm; petiole 1.5-4 cm long. Inflorescence 10-30 cm long, many-flowered. Flowers small, white or creamy white; pedicel and ovary 5-7 mm long. Dorsal sepal ovate, subacute, 3-4 × 1.25-1.75 mm. Lateral sepals obliquely oblong-ovate, obtuse, 3-4×1-1.25 mm. Petals narrowly elliptic, obtuse, 3-3.5 $\times 0.7-1 \mathrm{~mm}$. Lip saccate, 3-3.5 $\times 1 \mathrm{~mm}$, mucronate at apex; calli papillate, 2 or 3 pairs. Column $1-1.5 \mathrm{~mm}$ long. Fig. 21.

Distribution. Tonga ('Eua, Kao, Late, Niuafo'ou, and Tafahi) and Niue. Also widely distributed from the Philippines and Indonesia through New Guinea and Palau to the Solomon Islands, Santa Cruz Islands, Vanuatu, New Caledonia, Fiji, Samoa, and Australia.

НАвітAт. Occasional in foothill to montane forest; 250-600 m.

Collections. 'Eua: Hotta 5517, 5557; Hurlimann 261, 262. Kao: Buelow 3190. Late: Buelow \& Sykes 165. Niuafo'ou: Buelow 2258. Tafahi: Buelow 1199. Niue: Sykes 53, 358, 394; Whistler 10740. 
2. Hetaeria whitmeei Rchb. f., J. Bot. 15: 133. 1877. Type: Samoa, Whitmee s.n. (holotype K!, isotype $\mathrm{W}$ !).

Adenostylis stricta Rolfe, J. Linn. Soc., Bot. 39: 177. 1909. Type: Viti Levu, Gibbs 667 (holotype $\mathrm{BM}$ !).

Habenaria sp. sensu Yuncker., B.P. Bishop Mus. Bull. 220: 87. 1959.

Hetaeria francisii Schltr., Repert. Spec. Nov. Regni Veg. 9: 161. 1911. Type: New Caledonia, Franc 767 (holotype $\mathrm{B} \dagger$, isotype P!).

Hetaeria polyphylla Rchb. f., Otia Bot. Hamburg. (as Etaeria): 52. 1878 \& Xenia Orchid. 3: 29. 1881. Type: Vanua Levu, USEE s.n. (holotype W!, isotype and photo AMES!).

Zeuxine betchei Schltr., Repert. Spec. Nov. Regni Veg. 9: 90. 1910. Type: Samoa, Betche 57 (holotype B!, isotype MEL).

Zeuxine sphaerocheila H. Fleischm. \& Rech., Denkschr. Kaiserl. Akad. Wiss., Wien. Math.Naturwiss. K1. 85: 251, t. 2, fig.6. 1910. Types: Samoa, Rechinger 1663, 3710 (syntypes W!).

Zeuxine triandra M. Hotta, Acta Phytotax. Geobot. 19: 156. 1963. Type: Tonga, Hotta 5332 (holotype KYO).

Terrestrial herb up to $60 \mathrm{~cm}$ in height. Leaves narrowly elliptic to lanceolate, acuminate, $10-22 \times 0.7-2.2$ $\mathrm{cm}$; petiole 2-3.5 cm long. Inflorescence pubescent, 20-40 cm long, laxly many-flowered. Flowers brownish white without, creamy within. Dorsal sepal ovate, subacute, 4-5 mm long. Lateral sepals obliquely oblongovate, subacute, 4-5.5 × 2-2.5 mm. Petals oblong, rounded at apex, 4-4.5 × 0.7-1 mm. Lip 4.5-5.5 × 3-4 mm, saccate at the base with two lamellate, papillate calli within and longitudinally divided by a shallow groove externally; apical part transversely oblong, 1-1.5 × 1.5-2 mm. Column ca. $1.5 \mathrm{~mm}$ long. Fig. 22.

Distribution. Tonga ('Eua). Also in New Caledonia, Fiji, and Samoa.

HAвітAт. Uncommon in lowland to montane forest that is often dominated by Dysoxylum tongense; 200-300 m.

Collections. 'Eua: Buelow 2507; Hotta 5332, 5334; Whistler 7421, 11703; Yuncker 15404.

\section{VRYDAGZYNEA}

Blume, Fl. Javae ser. 2, 1, Orch.: 59. 1858.

Small terrestrial herbs with creeping fleshy rhizomes rooting at the nodes, and erect leafy stems. Leaves entire, alternate, petiolate, sheathing at the base, membranous. Inflorescence terminal, racemose, laxly to densely many-flowered. Flowers small, resupinate. Dorsal sepal entire, adnate to the petals and forming a hood over the column. Lateral sepals similar to the dorsal but oblique at the base. Petals entire, membranous. Lip more or less parallel to the column, entire, prominently spurred at the base, the spur projecting between the lateral sepals, entire or bilobed at apex, with two stalked glands within. Column very short; anther erect, persistent; pollinia two, sectile, clavate, attached to a common viscidium; rostellum relatively short, bilobed.

A small genus of perhaps 20 species in India, S.E. Asia, the Malay Archipelago, northern Australia, and the S.W. Pacific islands. A single species is reported from Tonga.

Vrydagzynea vitiensis Rchb. f., Otia Bot. Hamburg.: 51. 1878. Types: Samoa, Wilkes s.n. (syntype W!); Fiji, Ovalau, Wilkes s.n. (lectotype W!, isolectotype AMES!).

Vrydagzynea whitmeei Schltr., Bull. Herb. Boissier, II, 6: 296. 1906. Type: Samoa, Whitmee s.n. (holotype $\mathrm{B} \uparrow$ ). 
Terrestrial herb 8-25 cm in height. Leaves lanceolate or narrowly ovate, acute, $3.5-6 \times 1.2-2 \mathrm{~cm}$, green with a central white stripe; petiole $0.8-1.5 \mathrm{~cm}$ long. Inflorescence densely many-flowered, $2-7 \mathrm{~cm}$ long; rachis short, sparsely villose. Flowers greenish white to white; pedicel and ovary 5-9 $\mathrm{mm}$ long. Dorsal sepal oblongovate, subacute, 3-3.5 × 1-1.5 mm. Lateral sepals oblong, obtuse, oblique at the base, 3-3.5 × 1.5-2 mm. Petals falcately linear-oblong, obtuse, $2-2.5 \times 1-1.5 \mathrm{~mm}$. Lip ovate, blunt with incurved sides, 2-2.5 × 1-1.7 $\mathrm{mm}$; spur conical, obscurely bilobed at apex, 2.5-3 mm long. Column 1.5-2 mm long. Fig. 23.

Distribution. Tonga (Tafahi). Also in Vanuatu, Fiji, and Samoa.

HaвiтAT. Uncommon in foothill to montane forest; 250 to ca. $600 \mathrm{~m}$.

Collections. Tafahi: Buelow 1255, 1300; Hurlimann 442.

\section{ZEUXINE}

Lindl., Coll. Bot., app. no.18. 1826.

Adenostylis Blume, Bijdr. Fl. Ned. Ind.: 414. 1825.

Monochilus Wall. ex Lindl., Gen. Sp. Orchid. Pl.: 486. 1840.

Small to medium-sized terrestrial herbs with creeping fleshy rhizomes rooting at the nodes. Stems erect, leafy, fleshy. Leaves entire, alternate, petiolate, sheathing at the base, membranous. Inflorescence terminal, racemose, few- to many-flowered. Flowers small, resupinate. Dorsal sepal entire, adnate to the petals to form a hood over the column. Lateral sepals free, similar to dorsal sepal but oblique at base. Lip more or less adnate to front of column, entire, saccate or cymbiform at the base, with two small glands within; the middle clawed, the apex broadened into a transverse blade. Column short; anther dorsal, erect, persistent; pollinia two, sectile, attached to a common rather large viscidium; rostellum prominent, rather broad, deeply divided.

A large genus of perhaps 70 species widespread in the Old World tropics from Africa, Madagascar, and India eastward to China, S.E. Asia, the Malay Archipelago, and the Pacific islands. A single species is reported from Tonga.

Zeuxine stenophylla (Rchb. f.) Benth. \& Hook. f. ex Drake, Ill. Fl. Ins. Pacif.: 312. 1892. Type: Samoa, Savai'i \& Tutuila, Wilkes s.n. (syntypes W!).

Adenostylis vitiensis Rolfe, J. Linn. Soc., Bot. 39: 177. 1909. Type: Viti Levu, Gibbs 618 (holotype BM!, isotype K!).

Monochilus stenophyllus Rchb. f., Otia Bot. Hamburg.: 52. 1878; Xenia Orchid. 3: 29. 1881.

Zeuxine vitiensis (Rolfe) L.O. Williams, Bot. Mus. Leafl. 5: 112. 1938.

Terrestrial herb (or sometimes epiphytic) $18-35 \mathrm{~cm}$ in height. Leaves lanceolate, acute, $1.8-5 \times 0.6-1.3$ $\mathrm{cm}$. Inflorescence laxly many-flowered; peduncle and rachis sparsely hairy; bracts lanceolate, acuminate, up to $8 \mathrm{~mm}$ long. Flowers white, sparsely hairy; pedicel and ovary 5-7 mm long, sparsely hairy. Dorsal sepal ovate, obtuse, $3-4 \times 2-3 \mathrm{~mm}$. Lateral sepals obliquely oblong-ovate, obtuse, $4-5 \times 2-3 \mathrm{~mm}$. Petals obliquely ovate, obtuse, 3-3.5 $\times 2-2.5 \mathrm{~mm}$. Lip 3.5-4 $\times$ ca. $2 \mathrm{~mm}$, recurved at apex; basal part bearing two recurved hook-like calli within; apical lamina transversely oblong, ca. $1 \times 2-2.5 \mathrm{~mm}$. Column $1.7-2 \mathrm{~mm}$ long. Fig. 24.

Distribution. Tonga (Kao and Tafahi). Also found in Vanuatu, Fiji, and Samoa. Haвitat. Uncommon on the ground or on the base of tree ferns in scrub forest; ca. $500 \mathrm{~m}$. Collections. Kao: Buelow 2949, 3118. Tafahi: Buelow 1266. 


\section{SPIRANTHES}

Rich., De Orchid. Eur.: 20, 28, 36. 1817.

Small to medium-sized terrestrial herbs with fasciculate fleshy roots. Leaves in a basal rosette or in lower part of stem. Inflorescence terminal, a spiralling raceme or spike of many small flowers, often pubescent or glandular. Flowers small, usually not opening widely, white, pink, or greenish. Dorsal sepal entire, adnate to the petals over the column. Lateral sepals similar but usually oblique at the base. Petals entire, membranous. Lip sessile or shortly clawed, entire or obscurely 3-lobed in apical part, hairy or glabrous on upper surface. Column rather short, lacking a foot; anther erect, dorsal; pollinia two, mealy, attached by a caudicle to a small viscidium; stigmas two, on each side under rostellum.

A genus of about 50 species, mostly in temperate North America and Central America, but with a few species in Europe and temperate Asia. A single species from the Himalayas and China into S.E. Asia, the Malay Archipelago, the S.W. Pacific islands, northern Australia, and eastward to Samoa (where it was recorded only recently; Cribb \& Whistler 1999) and western Polynesia. The single species if reported from Tonga and Niue.

Spiranthes sinensis (Pers.) Ames, Orchidaceae 2: 53. 1908. Type: China, collector not traced (holotype UPS!).

Neottia sinensis Pers., Syn. P1. 2: 511. 1807.

Spiranthes neocaledonica Schltr., Bot. Jahrb. Syst. 39: 51. 1906. Type: New Caledonia, Schlechter 15594 (holotype B†). For full synonymy, see Garay \& Sweet. 1974.

Terrestrial herb 8-40 $\mathrm{cm}$ in height. Leaves mostly basal, oblong-elliptic to linear-lanceolate, grass-like, up to $10 \times 1 \mathrm{~cm}$. Inflorescence erect, spiralled, slender, laxly many-flowered; bracts ovate-lanceolate, 5-8 mm long, glabrous. Flowers white or pink with a white lip, apparently self-pollinating; pedicel and ovary up to 6 $\mathrm{mm}$ long. Dorsal sepal ovate, acute, 3.2-4 × 1-1.4 mm. Lateral sepals oblong-lanceolate, acute, $2.3-4.5 \times$ ca. $1 \mathrm{~mm}$. Petals oblong-lanceolate, rounded and erose at the apex, 2.8-4 $\times 0.7-1 \mathrm{~mm}$. Lip oblong-obovate, rounded at the apex, slightly constricted and papillose in apical third, 4-5 $\times 2-2.5 \mathrm{~mm}$, the apical margins undulate-crispate; calli basal, subglobose, fleshy. Column ca. 2 mm long. Fig. 25.

Distribution. Tonga (Ha'apai, Tofua, and Late) and Niue. Also widely distributed from mainland Asia, S.E. Asia, and the Malay Archipelago to New Guinea, the Solomon Islands, Vanuatu, Samoa, Australia, and New Caledonia.

НАвітAт. Uncommon in open areas, especially open scrub; up to $300 \mathrm{~m}$ (higher elsewhere).

Collections. Ha'apai: Yuncker 15775. Tofua: Buelow 2697; Hotta 4401; Whistler 10623. Late: Buelow \& Sykes 68, 221. Niue: Sykes 440, 692; Whistler 10820.

\section{Peristylus}

Blume, Bijdr. Fl. Ned. Ind.: 404. 1825.

Terrestrial herbs growing from tubers or clustered thickened roots, with short or long, leafy stems. Leaves in a basal rosette or alternate along stem, entire, fleshy-membranous, not articulated. Inflorescence terminal, laxly to densely many-flowered, racemose. Flowers small, green or yellow-green, resupinate. Dorsal sepal entire, adnate to petals to form a hood over the column. Lateral sepals spreading, reflexed or erect. Petals membranous, entire. Lip connate at base with margins of the column, 3-lobed or entire, spurred at the base, rarely with a fleshy callus in the mouth of the spur.Column very short, erect; anther persistent, bilocular; pollinia two, clavate, each attached to a small viscidium; rostellum small; stigmas two, sessile, adnate to the base of the lip and auricles of the column. 
A genus of about 70 species in tropical Asia, S.E. Asia, the Malay Archipelago, and S.W. Pacific islands. Two species are reported from Tonga and one from the Cook Islands.

\section{Key to Species}

1. Spur of lip cylindrical, $5-7.5 \mathrm{~mm}$ long

1. P. tradescantifolius

1. Spur of lip globular, ca. $2 \mathrm{~mm}$ long

2. Leaves clustered in middle of stem; sepals $3 \mathrm{~mm}$ long

2. P. novo-ebudarum

2. Leaves well spaced along center part of stem; sepals $2 \mathrm{~mm}$ long or less

3. P. minimiflorus

1. Peristylus tradescantifolius (Rchb. f.) Kores, Allertonia 5 (1): 12. 1989. Type: Ovalau, Seemann 608 (holotype W!, isotype AMES!, K!).

Habenaria cyrtostigma Schltr., Repert. Spec. Nov. Regni Veg. 9: 83. 1910. Type: Samoa, Rechinger 32; Samoa, Vaupel 584; Samoa, Rechinger 1146 (all syntypes B $†$ ).

Habenaria papuana Kraenzl., Bot. Jahrb. Syst. 18: 188. 1894. Type: New Guinea, Hellwig 585 (holotype $\mathrm{B} \dagger$ ).

Habenaria tradescantifolia Rchb. f., Seem., Fl. Vit.: 293. 1868.

Habenaria tradescantifolia Rchb. f. var. pinquior H. Fleischm. \& Rech., Denkschr. Kaiserl. Akad. Wiss., Wien. Math.-Naturwiss. K1. 85: 250. 1910. Types: Samoa, 'Upolu, Rechinger 1146 (syntype BM!, W!), 1802 (syntype W!).

Peristylus papuanus (Kraenzl.) J.J. Sm., Nova Guinea 12: 3. 1913.

Terrestrial herb 30-65 $\mathrm{cm}$ in height. Leaves 7 or 8, scattered in upper half of stem, lanceolate, longacuminate, $8-20 \times 1-2.8 \mathrm{~cm}$, subtended by 5 or 6 sheathing cataphylls. Inflorescence $19-55 \mathrm{~cm}$ long, laxly many-flowered; bracts 5-14 mm long. Flowers pale green or greenish white; pedicel and ovary 10-13 mm long. Dorsal sepal ovate, obtuse, 2.3-3.2 × 1.2-2 mm. Lateral sepals obliquely oblong-elliptic, obtuse, 2.5-3 $\times 1-1.5 \mathrm{~mm}$. Petals obliquely ovate, obtuse, 2.5-3.3 × 1.5-2 mm. Lip 3-lobed, obscurely 3-ridged at base; side lobes linear-tapering, recurving towards apex, $4.2-5.5 \mathrm{~mm}$ long; midlobe triangular-ligulate, fleshy, $1.5-2 \mathrm{~mm}$ long; spur cylindrical-fusiform, slightly incurved, 5-7.5 mm long. Column ca. $1 \mathrm{~mm}$ long. Fig. 26.

Distribution. Tonga ('Eua, Kao, and Tofua). Also found on Fiji and Samoa.

Навітат. Uncommon in lowland to montane forest; 200-1000 m.

Collections. 'Eua: ?Buelow 2517. Kao: Buelow 2928, 2943. Tofua: Buelow 2734.

2. Peristylus novoebudarum F. Muell., Contr. Phytogr. New Hebrides: 22. 1873. Type: Vanuatu, Campbell s.n. (holotype MEL).

Terrestrial herb up to $60 \mathrm{~cm}$ or more in height. Leaves clustered in middle of stem, lanceolate, acuminate, $10-17 \times 1.5-2.5 \mathrm{~cm}$; petiole $1-1.5 \mathrm{~cm}$ long. Inflorescence up to $30 \mathrm{~cm}$ long, subdensely many-flowered; bracts lanceolate, $1-1.5 \mathrm{~cm}$ long, equaling or longer than the flowers. Flowers pale greenish yellow to yellowish brown, small; pedicel and ovary ca. $0.8 \mathrm{~cm}$ long. Dorsal sepal ovate, obtuse, ca. $3 \times 1.5 \mathrm{~mm}$. Lateral sepals oblong-ovate, shortly mucronate, ca. $3 \times 1-1.5 \mathrm{~mm}$. Petals entire, obliquely ovate, obtuse, ca. $3.5 \times 1 \mathrm{~mm}$. Lip 3-lobed, with a horn-like callus at mouth of spur; side lobes spreading, linear-tapering, ca. $3 \mathrm{~mm}$ long; midlobe ligulate, obtuse, fleshy, ca. $2 \mathrm{~mm}$ long; spur globular, ca. $2 \mathrm{~mm}$ long. Column very short, ca. $1 \mathrm{~mm}$ long. No Fig. available.

Distribution. Tonga ('Eua, Kao, and Niuafo'ou). Also in Vanuatu and New Caledonia.

НАВітAт. Rare in lowland to montane and ridge-top forest; up to $800 \mathrm{~m}$.

Collections. 'Eua: Buelow 2517. Kao: ?Buelow 618. Niuafo'ou: Buelow 2146. 
3. Peristylus minimiflorus (Kraenzl.) N. Hallé, Fl. Nouv.-Caléd. 8: 552. 1977. Type: New Caledonia, Le Rat 98, pro parte (holotype $\mathrm{P}$ !).

Eulophia minimiflora Kraenzl., Lecomte, Notul. Syst. (Paris) 4: 137. 1928, pro parte.

Terrestrial herb 35-45 cm or more in height. Leaves 6-8, scattered in central part of stem, lanceolate, acuminate, $6-8 \times 1.4-2.1 \mathrm{~cm}$; petiole $1-1.5 \mathrm{~cm}$ long. Inflorescence $22-25 \mathrm{~cm}$ long, subdensely many-flowered; bracts lanceolate, ca. $1 \mathrm{~cm}$ long. Flowers pale greenish yellow, small; pedicel and ovary ca. $0.8 \mathrm{~cm}$ long. Dorsal sepal ovate, obtuse, ca. $2 \times 1 \mathrm{~mm}$. Lateral sepals oblong-ovate, shortly mucronate, ca. $2 \times 1 \mathrm{~mm}$. Petals entire, obliquely ovate, obtuse, ca. $2 \times 0.6 \mathrm{~mm}$. Lip 3-lobed; side lobes obscure; midlobe ligulate, obtuse, fleshy, ca. 2 $\mathrm{mm}$ long; spur globular, ca. $1.5 \mathrm{~mm}$ long. Column very short, ca. $1 \mathrm{~mm}$ long. No Fig. available.

Distribution. Cook Islands (Rarotonga and Miti'aro). Also in New Caledonia.

НАвітAт. Rare in lowland to montane and ridge-top forest; up to $800 \mathrm{~m}$.

Collections. Rarotonga: Luttrell \& McCormack 168A. Miti'aro: Sykes 1035, 2384.

\section{HABENARIA}

Willd., Sp. Pl. 4: 44. 1805.

Terrestrial herbs growing from underground tubers, with erect leafy stems. Leaves in a basal rosette or borne on stem, entire, membranous, not articulated. Inflorescence terminal, few- to many-flowered, racemose. Flowers green, white, yellow, rarely red or orange, small to large, resupinate. Dorsal sepal entire, often adnate to the petals or the posterior petal lobes to form a hood over the column. Lateral sepals spreading to reflexed, entire. Petals entire or bilobed. Lip 3-lobed or 3-partite, rarely entire, spurred at base; side lobes spreading, sometimes further divided; midlobe usually pendent. Column erect, small to large; anther erect, persistent, bilocular; pollinia two, clavate, each attached to a small viscidium; rostellum 3-lobed, more or less triangular; stigmas two, stalked.

A genus of between 600 and 800 species, pantropical in distribution, but extending into warm temperate regions. A single species is reported from the Cook Islands.

Habenaria amplifolia Cheeseman, Trans. Linn. Soc. London, Bot. 6: 298. 1903. Type: Rarotonga, Cheeseman s.n. (holotype K!)

Terrestrial herb $75-160 \mathrm{~cm}$ in height. Leaves in central part of stem, elliptic-lanceolate to obovate, acuminate, 18-29 × 3.8-7 cm. Inflorescence subdensely many-flowered, up to $100 \mathrm{~cm}$ long; bracts lanceolate, acuminate, 13-18 mm long. Flowers green. Dorsal sepal ovate-elliptic, aristate, $12-13 \times 4-5 \mathrm{~mm}$. Lateral sepals obliquely ovate, aristate $11-12 \times 3-3.5 \mathrm{~mm}$. Petals bipartite; posterior lobe broadly linear-lanceolate, acuminate, $10-11 \times 0.2-0.5 \mathrm{~mm}$; anterior lobe falcate, much shorter than posterior lobe, linear, acuminate, incurved, 6-6.5 × 0.3-0.4 mm. Lip 3-lobed; side lobes incurved, linear-tapering, 6-7 mm long; midlobe longer than side lobes, linear, acute, ca. $10 \times 1 \mathrm{~mm}$; spur more or less straight or sinuous, longer than ovary, 25-30 $\mathrm{mm}$ long, filiform, inflated at apex. Column 2-2.5 mm long. Figs. 27, 67.

Distribution. Rarotonga. Endemic to the island.

HaвiтAT. Locally common in shaded forested ravines in center of island; ca. $250 \mathrm{~m}$.

Collections. Rarotonga: Cheeseman s.n.; Parks 22288; Sykes 1705, 2583; Whistler 5937; Wilder 792.

\section{CORYMBORKIS}

Thouars, Nouv. Bull. Sci. Soc. Philom. Paris 1: 318. 1809.

Corymborchis Blume, Fl. Javae ser. 2, 1, Orch.: 105. 1858-9.

Corymbis Thouars, Seem., Fl. Vit.: 295 (1868). 
Large terrestrial herbs with woody, bamboo-like, erect leafy stems growing from short rhizomes, often forming clumps; roots fibrous, fasciculate. Leaves in upper half of stem, plicate, ovate, elliptic or lanceolate. Inflorescence axillary, simple or branching. Flowers not opening widely, resupinate. Sepals and petals free or shortly connate, linear-oblanceolate, subsimilar. Lip parallel to column, spathulate, recurved at apex, with two longitudinal callus ridges. Column elongate, slender, clavate, straight; pollinia two, granulose, with a slender terete stipe attached to a peltate viscidium; rostellum bilobed.

A pantropical genus of seven species, with one species found in Tonga.

Corymborkis veratrifolia (Reinw.) Blume, Fl. Javae, ser. 2, 1, Orch.: 125 (1859). Type: Java, Lobb 162 (neotype K!). For full synonymy, see Rasmussen (1977).

Large terrestrial herb with stems up to $1.2 \mathrm{~m}$ in height, leafy in apical half, often forming colonies. Leaves elliptic to lanceolate, acuminate, 20-32 $\times 4-9 \mathrm{~cm}$, narrowed into a short petiole above the sheathing base. Inflorescence 1-several, up to $16 \mathrm{~cm}$ long, lateral from the leaf axils in upper part of stem, usually branching; bracts lanceolate, acuminate, $8-10 \mathrm{~mm}$ long. Flowers white or greenish white, narrow and tubular, not opening widely; pedicel and ovary up to $2 \mathrm{~cm}$ long. Sepals and petals similar, linear-oblanceolate, acute, 20-23 × 1.5-2 $\mathrm{mm}$. Lip spathulate, 18-20 $\times 5-7 \mathrm{~mm}$, claw linear, apical lamina suborbicular-ovate, shortly apiculate, margins crispate. Column 15-16 mm long. Capsule stalked. Fig. 28.

Distribution. Tonga ('Eua and Tongatapu). Widely distributed from S.E. Asia and the Malay Archipelago to New Guinea, Australia, the Solomon Islands, Vanuatu, Fiji, and Samoa.

НавітAт. Occasional in lowland forest, less common in upper montane rainforest; ca. 20-650 m.

Collections. 'Eua: Hotta 5251, 5285, 5295; Hurlimann 253; Ives s.n.; Sykes 137, 623; Whistler 5982, 6474; Wood 6845; Yuncker 15467. Tongatapu: Buelow 51; Ilolahia 95; Palmer 125; Parks $15468,15623$.

TONGAN NAME: 'Uto'uto.

\section{NERVILIA}

Commerson ex Gaudich., Voy. Uranie: 421. 1829.

Small to medium-sized terrestrial herbs growing from underground tubers. Leaf solitary, usually produced after the inflorescence has withered, ovate, lanceolate, elliptic, or heart-shaped, erect or borne parallel to the substrate, either appressed to the substrate or above it, glabrous to hairy, green or marked with purple on upper side, green or purple beneath. Inflorescence lateral, one- to several-flowered, erect, racemose. Flowers shortlived, resupinate. Sepals subsimilar, linear-lanceolate. Petals similar but shorter and membranous. Lip more or less embracing the column, entire to 3-lobed, bearing a lamellate or hairy callus, rarely spurred at base. Column clavate, elongate; anther incumbent, 2-celled; pollinia two, granulose, lacking caudicles; stigma below rostellum.

A genus of about 80 species in Africa, Madagascar, tropical Asia, the Malay Archipelago, Australia, and the S.W. Pacific islands. One species is reported from Tonga, the Cook Islands, and Niue.

Nervilia concolor (Blume) Schltr., Bot. Jahrb. Syst. 45: 404. 1911. Type: Java, Mt. Salak, Blume s.n. (holo. L).

Gastrodia sp. sensu Kraenzl., Bot. Jahrb. Syst. 25: 599. 1898.

Nervilia aragoana Gaudich., Voy. Uranie: 422. 1829. Type: Mariana Islands, Gaudichaud s.n. (holotype P!).

Pogonia concolor Blume, Mus. Bot. 1: 32. 1825. 

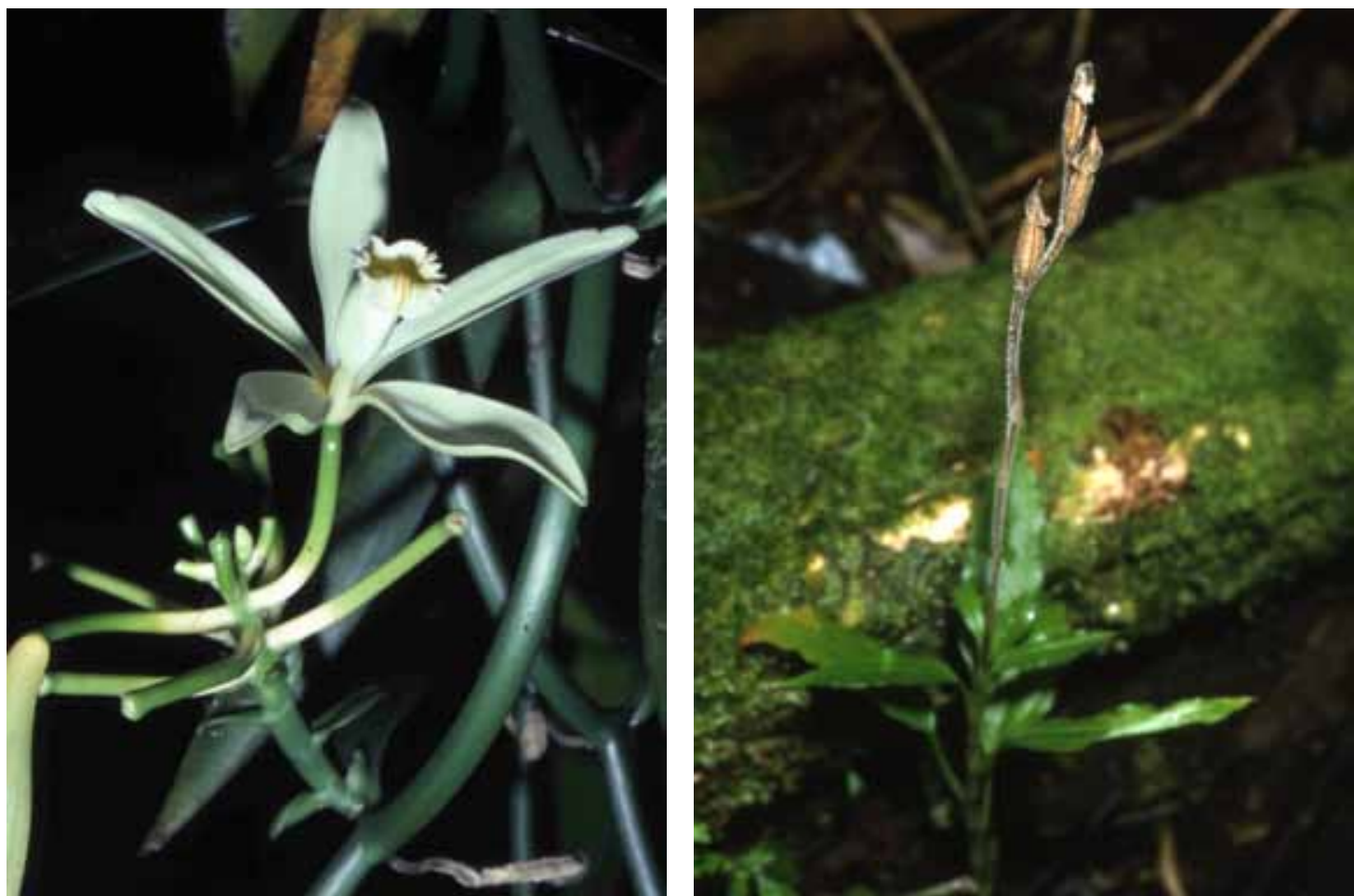

FigURE 17. Vanilla planifolia.

FIGURE 18. Erythrodes oxyglossa. Tonga.

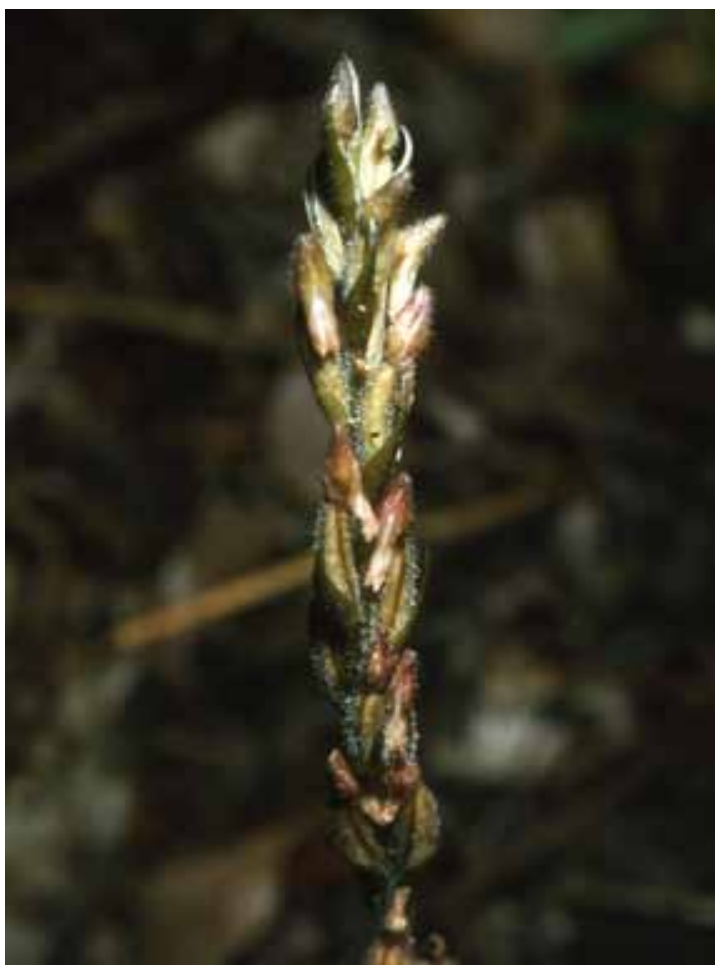

FIGURE 19. Erythrodes purpurascens. Tonga.

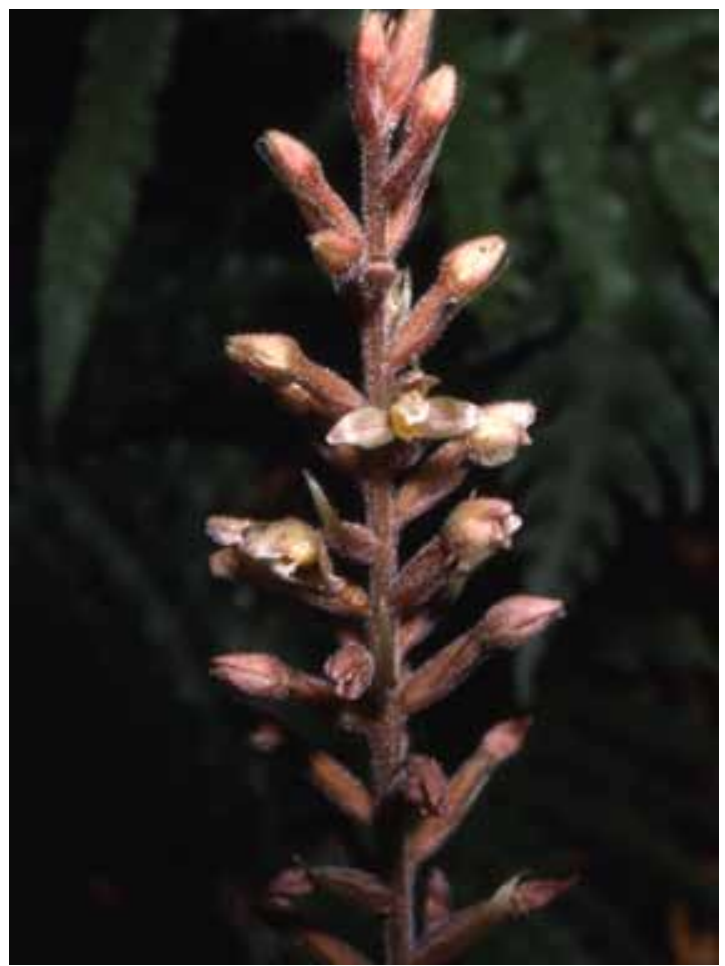

FIGURE 20. Goodyera rubicunda. Tonga.

LANKESTERIANA 11(2), August 2011. (C) Universidad de Costa Rica, 2011. 


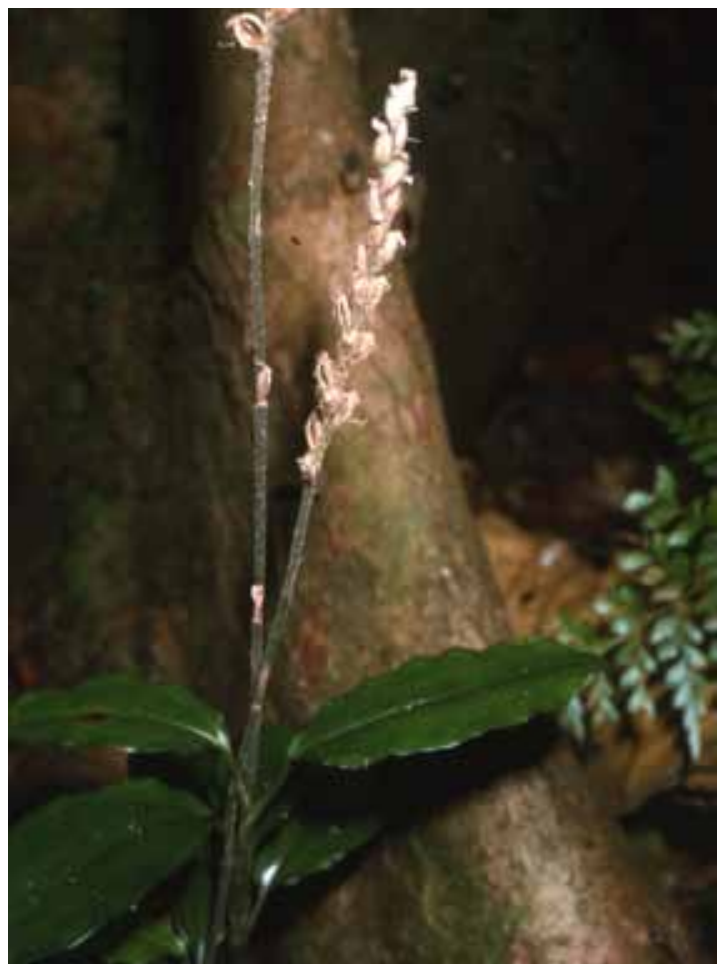

FiguRE 21. Hetaeria oblongifolia. Niue.

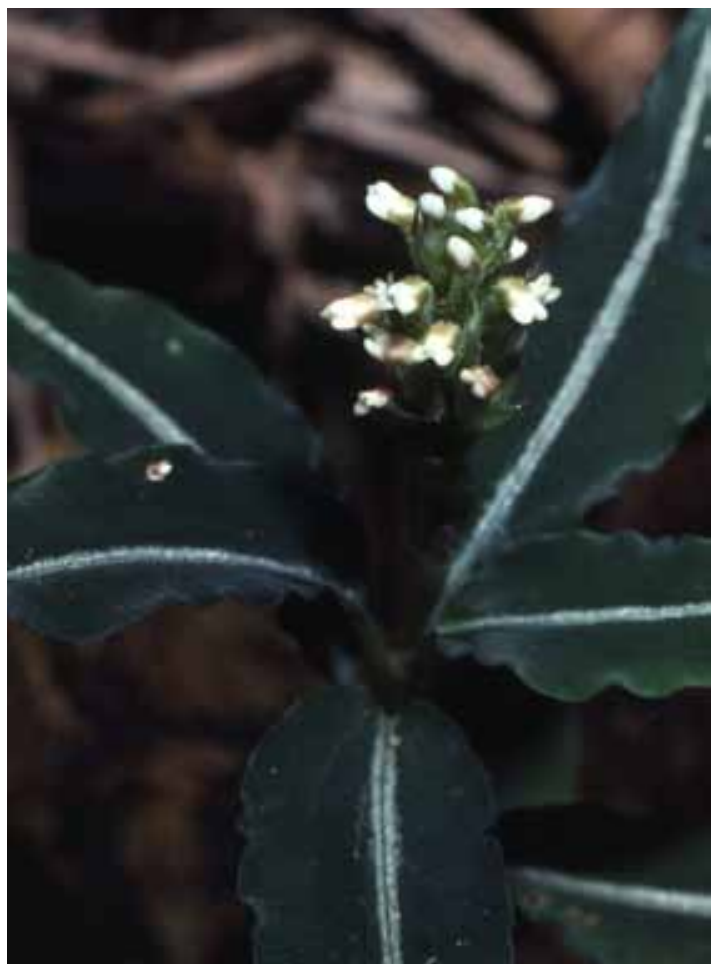

FIgURE 23. Vrydagzynea vitiensis. Samoa.

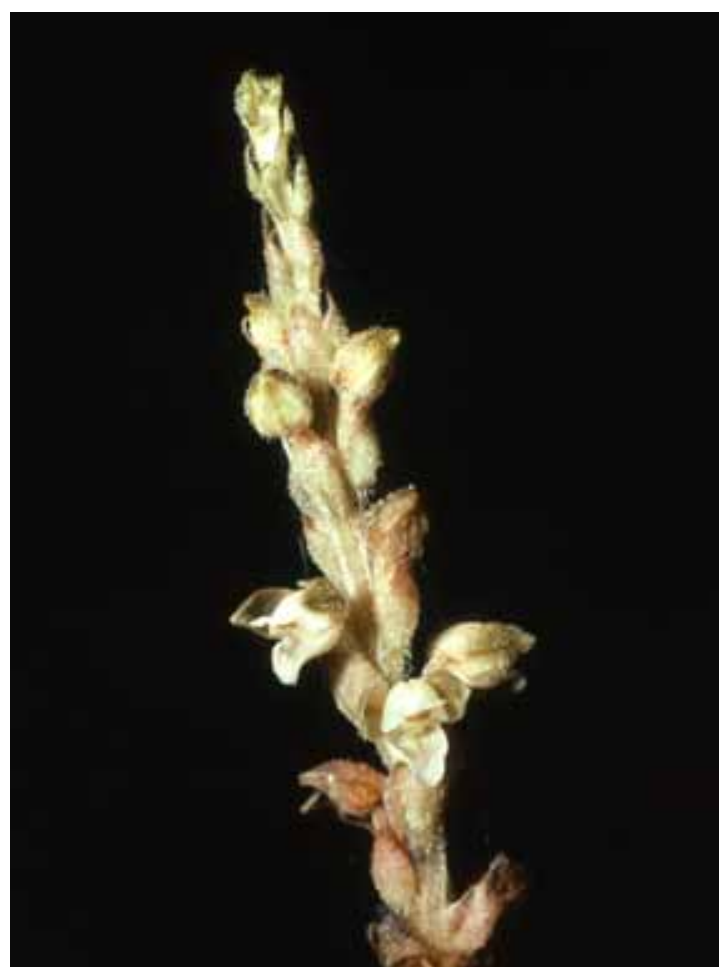

FIGURE 22. Hetaeria whitmeei. Samoa.

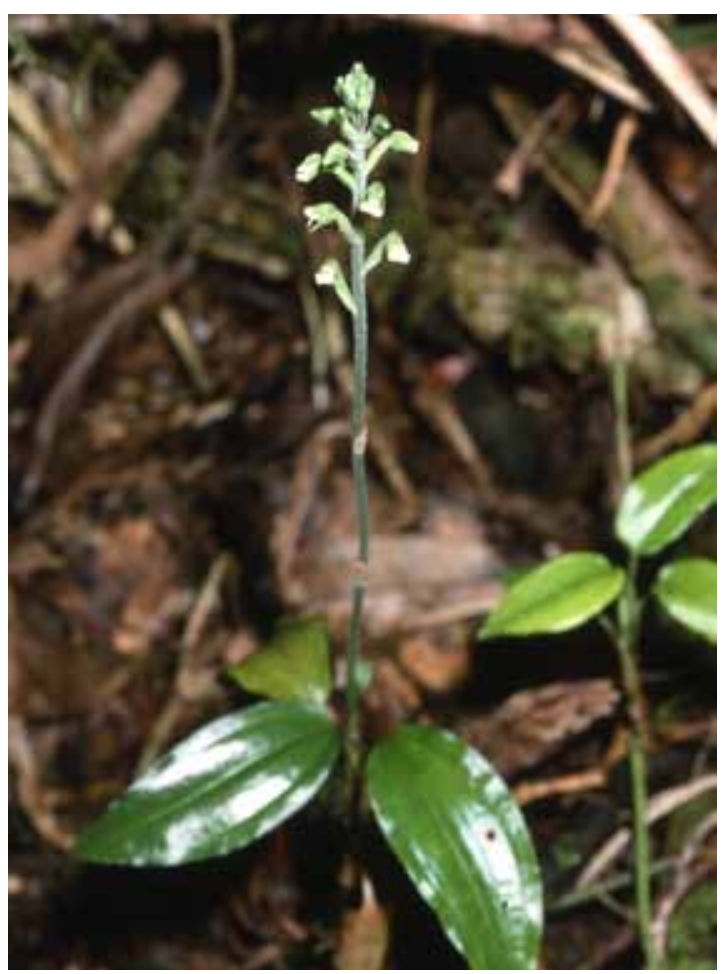

FIGURE 24. Zeuxine stenophylla. Samoa. 

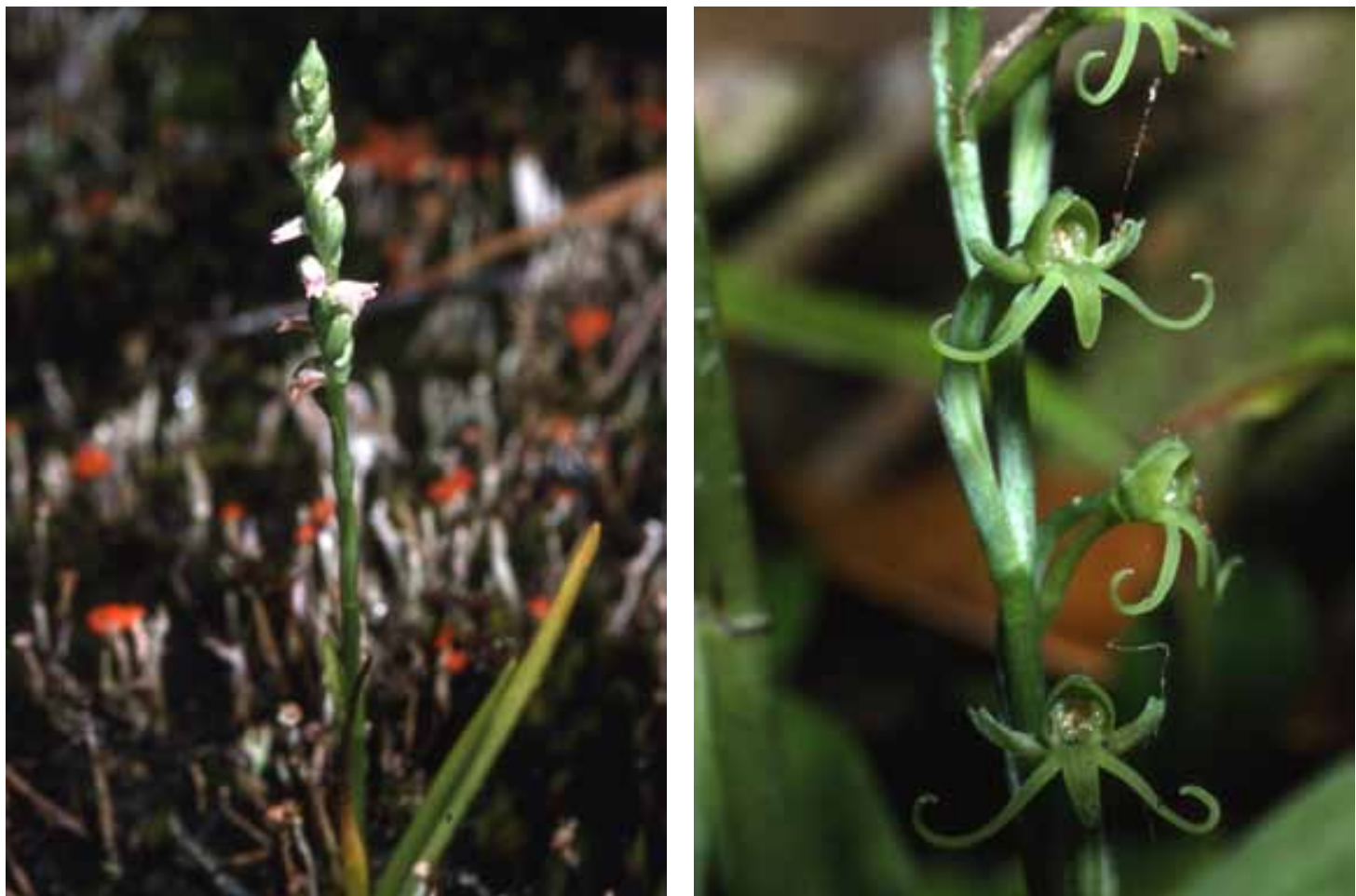

FIGURE 25. Spiranthes sinensis. Samoa.

FIgURE 26. Peristylus tradescantifolius. Samoa.
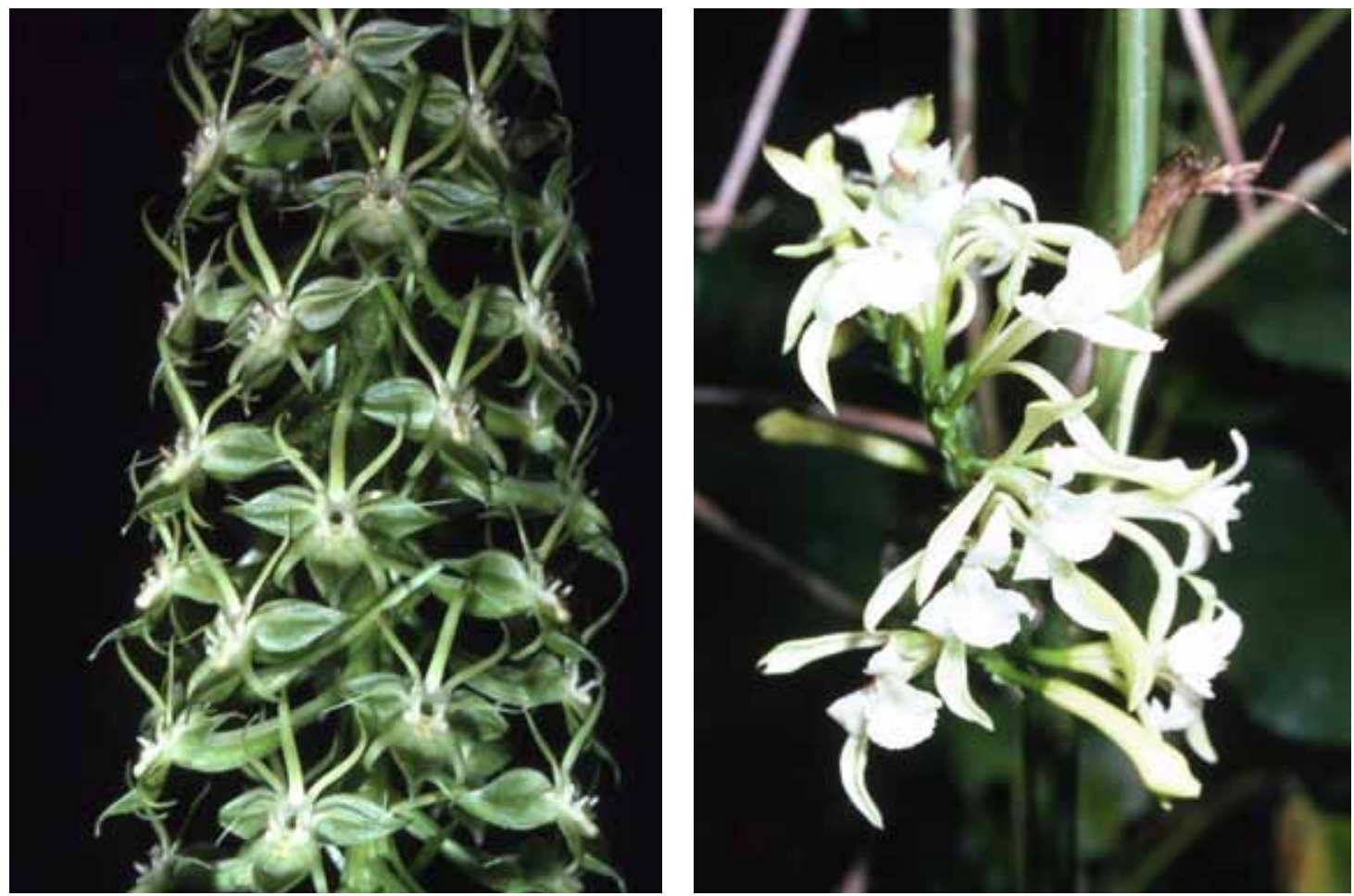

Figure 27. Habenaria amplifolia. Cooks.

FIGURE 28. Corymborkis veratrifolia. Tonga.

LANKESTERIANA 11(2), August 2011. (C) Universidad de Costa Rica, 2011. 

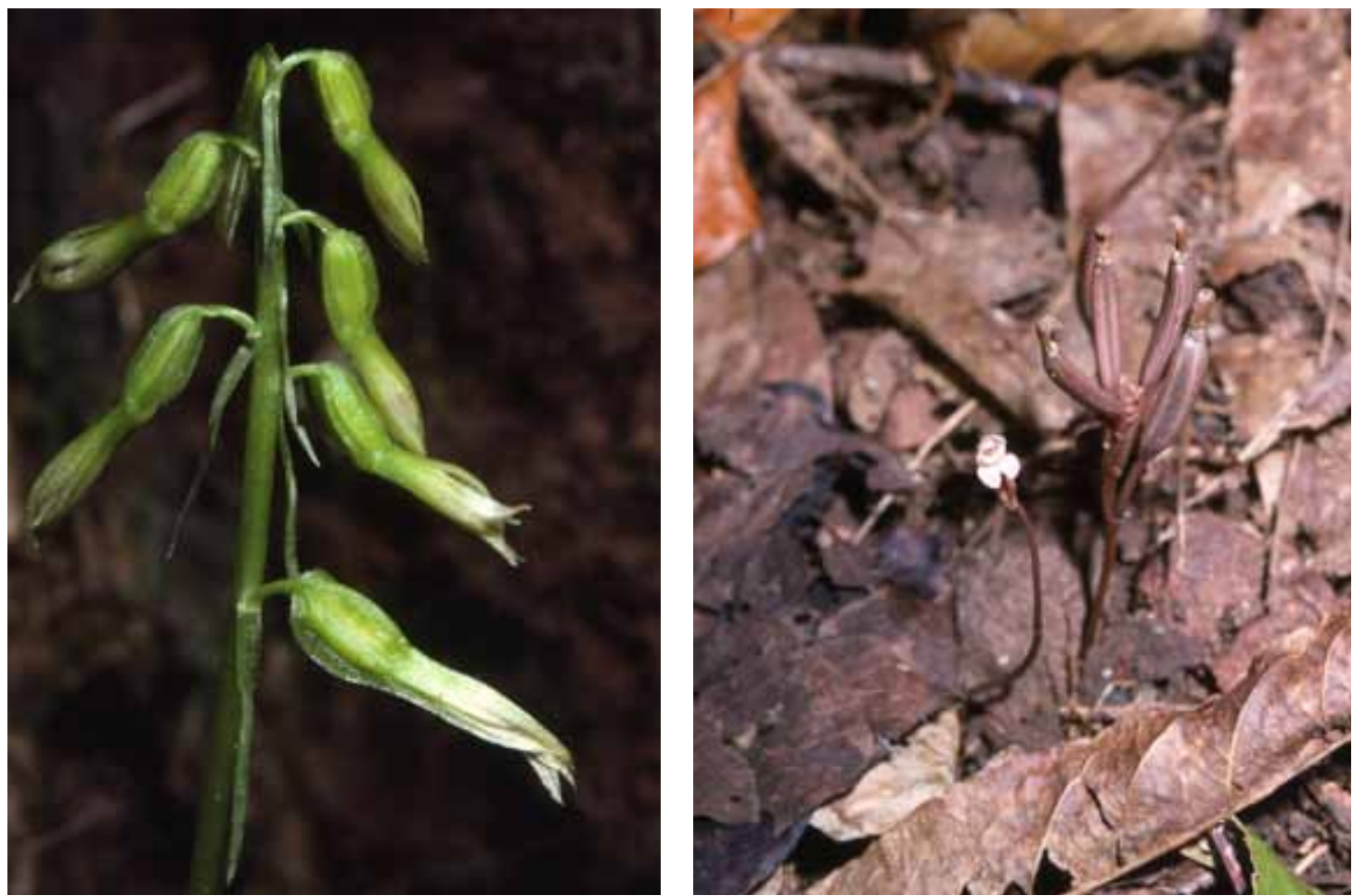

Figure 29. Nervilia concolor. Tonga.

Figure 30. Didymoplexis micradenia. Rotuma.
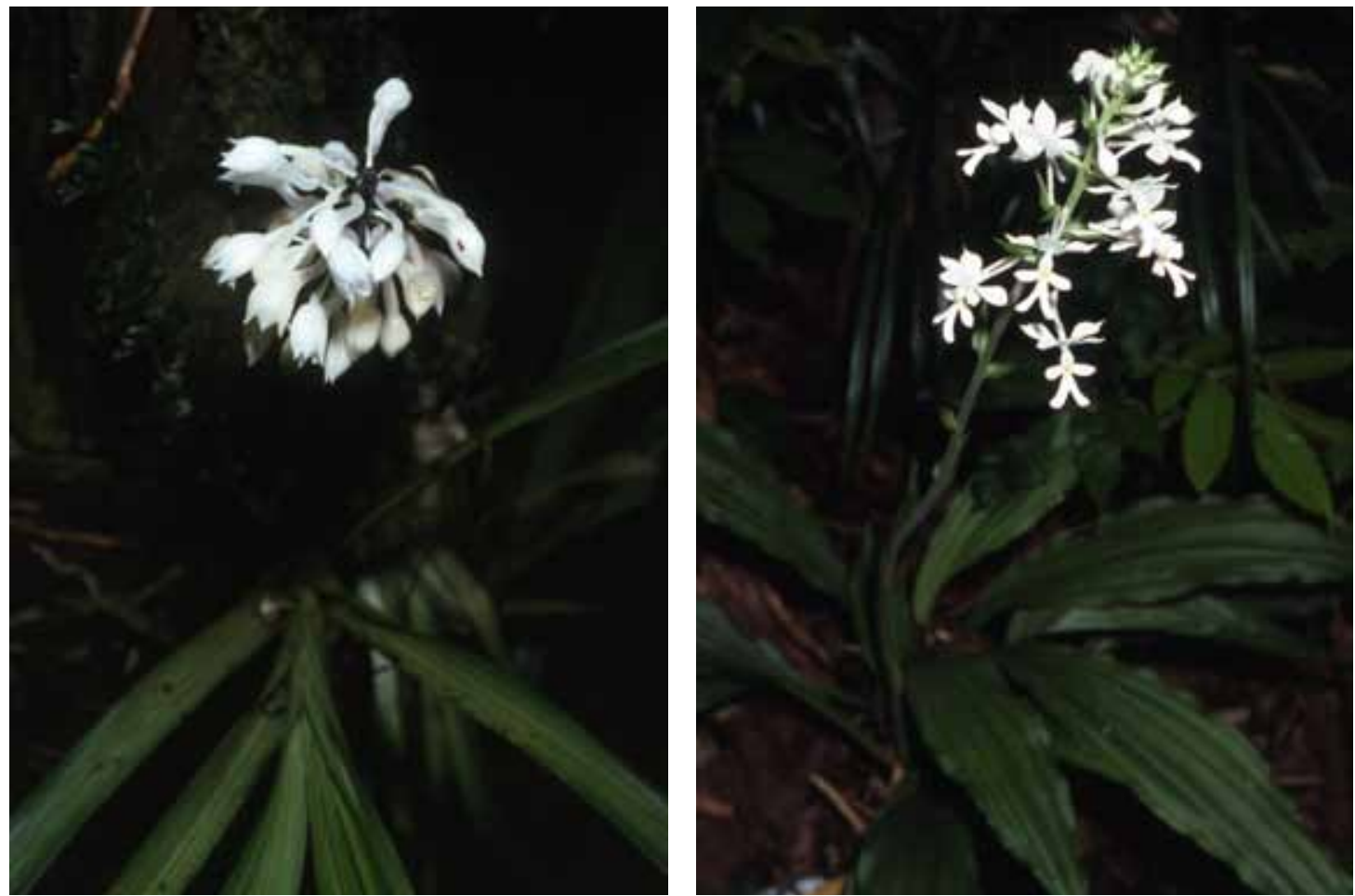

Figure 32. Calanthe triplicata. Samoa. 
Pogonia flabelliformis Lindl., Gen. Sp. Orchid. P1.: 415. 1840, nom. illeg. Type: Nepal, Wallich $7400 A$ (holotype K!).

Pogonia nervilia Blume, Mus. Bot. 1:. 1849, 32 nom. illeg. based on the types of both above.

Terrestrial stemless herb arising from an underground tuber. Leaf erect, plicate, heart-shaped, acute, 12-15 $\times 14-18 \mathrm{~cm}$, often marked with dark maroon on upper surface; petiole 15-30 cm long. Inflorescence laxly 5-15-flowered, up to $45 \mathrm{~cm}$ long; bracts linear to linear-lanceolate, 15-25 mm long. Flowers pendent or nodding, probably self-pollinating, white or greenish yellow with a white lip marked with rose or violet veins; pedicel and ovary 1-1.5 cm long. Sepals and petals linear-lanceolate, acute, 2-2.5 cm long. Lip 3-lobed near the apex, 2-2.4 cm long; side lobes small, erect, triangular; midlobe subovate, acute to obtuse, with undulate margins; callus puberulent in middle. Column clavate, ca. 7 mm long. Fig. 29.

Distribution. Tonga (Tongatapu, Vava'u, Niuatoputapu, Niuafo'ou, and Tafahi), the Cook Islands (Atiu, Mangaia, Mauke, and Miti 'aro), and Niue. Also widely distributed from Asia and the Malay Archipelago to the Mariana Islands, New Guinea, the Solomon Islands, Vanuatu, New Caledonia, the Horne Islands, Samoa, the Society Islands, Fiji, and Australia.

НАвітAт. Uncommon in lowland to montane forest; 10-500 m.

Collections. Tongatapu: USEE s.n. Vava'u: Whistler (sight record, 2002). Niuafo'ou: Buelow 1996, 2185, 2216; Whistler 6416. Niuatoputapu: Buelow 1141. Tafahi: Hurlimann 475; Whistler 6238. Atiu: Sykes 350; Whistler 5678. Mangaia: Whistler 5467. Mauke: Whistler 5541. Miti'aro: Whistler 5268. Niue: Sykes 791, 820, 1038; Yuncker 10057.

Cook Islands name: Pia rau ta'i, tamaru (Miti'aro).

\section{DiDYMOPLEXIS}

Griffith, Calcutta J. Nat. Hist. 4: 383. 1843.

Small saprophytic herbs growing from a tuberous rhizome, with fleshy, glabrous, erect stems bearing a few cataphylls, but lacking chlorophyll and leaves. Inflorescence few-flowered, racemose. Flowers resupinate, small, lacking a spur. Dorsal sepal adnate to petals and forming a hood over the column. Lateral sepals free or fused to each other for at least part of length. Lip 3-lobed, attached to column-foot; callus of rows of papillae. Column free, elongate, with a short foot; anther declinate; pollinia two, sectile, lacking caudicles; rostellum short. Capsule with a stalk that elongates rapidly after pollination.

A small genus of about 20 species in tropical Africa, Madagascar, tropical Asia eastward to the Ryukyu Islands, the Malay Archipelago, Northern Australia, and the S.W. Pacific. A single species is reported from Tonga and Niue.

Didymoplexis micradenia (Rchb. f.) Hemsl., J. Linn. Soc., Bot. 20: 311. 1883. Type: Ovalau, Seemann 610 (holotype W!, isotype K!).

Didymoplexis minor J.J. Sm., Bull. Inst. Bot. Buitenzorg 7: 1. 1900. Type: Java, J.J. Smith 74 (holotype L!).

Didymoplexis minor subsp. samoensis H. Fleischm. \& Rech., Denkschr. Kaiserl. Akad. Wiss., Wien. Math.-Naturwiss. K1. 85: 251. 1910. Type: Samoa, Rechinger 1641 (holotype W!).

Didymoplexis neocaledonica Schltr., Bot. Jahrb. Syst. 39: 50. 1906. Type: New Caledonia, Schlechter 15748 (holotype B†).

Didymoplexis pallens sensu Sykes, New Zealand Dept. Sci. Indust. Res. Bull. 200: 258. 1970, non Griff. 
Didymoplexis samoensis (H. Fleischm. \& Rech.) Schltr., Repert. Spec. Nov. Regni Veg. 9: 85. 1910. Epiphanes micradenia Rchb. f., Seem., Fl. Vit.: 295. 1868.

Leucorchis micradenia (Rchb. f.) Benth. \& Hook. f. ex Drake, Ill. Fl. Ins. Pacif.: 313. 1892.

Leafless herb $7-10 \mathrm{~cm}$ in height, elongated in fruit up to $25 \mathrm{~cm}$ in height, with irregularly cylindricalfusiform tubers up to $4 \mathrm{~cm}$ long and $0.8 \mathrm{~cm}$ in diameter; roots slender, filiform. Inflorescence erect, slender, up to $10 \mathrm{~cm}$ long, pinkish brown; peduncle bearing 2 or 3 short, sheathing cataphylls; bracts ovate-acuminate, $1-1.5$ $\mathrm{mm}$ long. Flowers small, dull flesh-brown with a whitish lip; peduncle elongating rapidly after fertilization, 5-20 cm long. Dorsal sepal oblong-ovate, blunt, adnate to petals, forming a hood over column, 5.5-6.6 $\times$ 2.5-3.5 mm. Lateral sepals almost fused, oblong to oblong-lanceolate, obtuse, 5-6 $\times 1.5-2 \mathrm{~mm}$. Lip oblongcuneiform, weakly 3-lobed at apex, 5.5-6.5 × 2.5-3 mm; callus of 3 ridges of papillae. Column $4.5-5.5 \mathrm{~mm}$ long; foot $0.3-0.5 \mathrm{~mm}$ long. Fig. 30.

Distribution. Tonga ('Eua, Tongatapu, Vava'u, Late, Niuatoputapu, and Tafahi) and Niue. Also in Vanuatu, New Caledonia, Fiji, and Samoa.

НавітAт. Uncommon in coastal to foothill forest; near sea level to $450 \mathrm{~m}$.

Collections. 'Eua: Buelow 1738. Tongatapu: Lawrence 218. Vava'u: Buelow \& Sykes 46. Late: Buelow \& Sykes 72. Niuatoputapu: Buelow 1422. Tafahi: Buelow 1325. Niue: Sykes 387, 459; Whistler 10787, 10880.

\section{Calanthe}

R. Br., Ker Gawler, Bot. Reg. 7: sub t. 573. 1821.

Medium-sized to large terrestrial herbs (or rarely epiphytic) with a short to elongate rhizome. Erect stems pseudobulbous or obscurely so, several-noded, leafy along length. Leaves pleated, not or rarely articulated, often quite large. Inflorescence lateral, erect, many-flowered, racemose. Flowers resupinate, usually showy, turning blue-black when damaged and with age; bracts persistent or rarely caducous. Sepals free, spreading. Petals smaller than sepals, free, spreading. Lip entire or more commonly 3- or 4-lobed, connate at base to column, spurred at base; callus papillate, ridged or verrucose at base of lip; spur usually long, rarely short or absent. Column short, fleshy, connate with base of lip; anther decumbent; pollinia eight, clavate, waxy.

A genus of about 260 species widely distributed in Africa, Madagascar, tropical and east temperate Asia, Japan, Taiwan, S.E. Asia, the Malay Archipelago, W. and S.W. Pacific islands, and Australia, and a single species in tropical America. Two species are reported from Tonga.

\section{Key to Species}

1. Lip 3-lobed, 6-7 mm long, lacking a basal callus; spur sigmoid, 12-14 $\mathrm{mm}$ long

1. C. hololeuca

1. Lip 4-lobed; $13-20 \mathrm{~mm}$ long with a basal yellow to red callus; spur pendent to horizontal, $15-30 \mathrm{~mm}$ long

2. C. triplicata

1. Calanthe hololeuca Rchb. f., Seem., Fl. Vit.: 298. 1868. Type: Viti Levu, Seemann 607 (holotype $\mathrm{K}$ !, part of holotype $\mathrm{W} !)$.

Calanthe neocaledonica Rendle, J. Linn. Soc., Bot. 45: 251. 1921. Types: New Caledonia, Compton 1409, 1609 (syntypes BM!).

Calanthe vaupeliana Kraenzl., Notizbl. Königl. Bot. Gart. Berlin 5: 111. 1909. Type: Samoa, Vaupel 397 (holotype B!, isotype AMES!, K!).

Large terrestrial herb 50-90 cm in height. Leaves 6-8, lanceolate, acute or acuminate, 30-50 × 3-6.8 cm; 
petiole 11-20 cm long. Inflorescence 27-65 cm long, subdensely many-flowered; peduncle terete, bearing several sheathing sterile bracts; rachis 6-15 cm long; bracts ovate-lanceolate, acute, 15-28 mm long, deciduous. Flowers white; pedicel and ovary 10-22 mm long. Sepals elliptic to oblong-ovate, acuminate or shortly apiculate, 11-14 $\times$ 4-6 mm. Petals elliptic to elliptic-obovate, acuminate, 10-13 × 4.5-8 mm. Lip 3-lobed, 6-7 × 4-5 mm, lacking a basal callus; side lobes upcurved, oblong, small; midlobe oblong-cuneate or oblong, truncate; spur cylindric to slightly clavate, 12-14 mm long, slightly sigmoid at apex. Column ca. $3 \mathrm{~mm}$ long. Fig. 31.

Distribution. Tonga (Kao and Tofua). Also from the Santa Cruz Islands, Vanuatu, New Caledonia, Fiji, Samoa, and the Horne Islands.

НавітAт. Common in foothill forest and on ridge tops; 350-400 m.

Collections. Kao: Buelow 2909; Hotta 4355. Tofua: Buelow 441, 2666.

2. Calanthe triplicata (Willemet) Ames, Philipp. J. Sci., Bot. 2: 326. 1907. Type: Philippines, Cuming 2064 (holotype BM!).

Calanthe angraeciflora Rchb. f., Linnaea 41: 75. 1877. Type: New Caledonia, Deplanche 114 (holotype P!).

Calanthe furcata sensu Yuncker, Bernice P. Bishop Mus. Bull. 184: 32. 1945, non Batem. ex Lindl. Calanthe nephroglossa Schltr., Repert. Spec. Nov. Regni Veg. 9: 99. 1911. Type: Samoa, Vaupel 413 (holotype $\mathrm{B} \dagger$, isotype $\mathrm{K}$ !).

Calanthe triplicata var. angraeciflora (Rchb. f.) N. Hallé, Fl. Nouv.-Caléd. 8: 230. 1977. Type: As for C. angraeciflora. For a full synonymy, see Garay and Sweet. 1974.

Calanthe veratrifolia (Willd.) R. Br., Bot. Reg. 9: sub t. 573. 1821; Ker-Gawl., op. cit. 9: t. 720. 1823. Limodorum veratrifolium Willd., Sp. P1. 4: 122 . 1804, nom. illeg.

Orchis triplicata Willemet, Ann. Bot. (Usteri) 18: 52. 1796. Lectotype: Maluku, Amboinia, icon. in Rumphius, Herb Amb. 6: t. 52, f. 2.

Large terrestrial herb $60-125 \mathrm{~cm}$ in height. Leaves elliptic-lanceolate, acuminate, 40-75 $\times 4-9 \mathrm{~cm}$; petiole 12-25 cm long. Inflorescence 60-125 cm long, laxly to subdensely many-flowered; peduncle pubescent, terete; rachis a quarter to half as long as peduncle; bracts lanceolate, acuminate. Flowers white with a whitish or yellow callus; pedicel and ovary 2-3 cm long. Sepals elliptic-obovate, abruptly acuminate, $12-20 \times 6-9 \mathrm{~mm}$. Petals ellipticoblanceolate or oblanceolate, acute, 10-18 $\times 4-7 \mathrm{~mm}$. Lip 4-lobed, 13-20 × 11-14 mm; side lobes obliquely oblongelliptic, rounded at apex; midlobe falcate, linear-oblong, spreading; callus of three short verrucose ridges at apex of column, yellow to red; spur filiform, 15-30 mm long, arcuate-dependent. Column 4-5 mm long. Fig. 32.

Distribution. Tonga (Kao, Tofua, Niuafo‘ou, and Tafahi). Widely distributed from Madagascar, Asia, and S.E. Asia to the Malay Archipelago, New Guinea, the Solomon Islands, Vanuatu, New Caledonia, Fiji, Samoa, the Marquesas, Lord Howe Island, and Australia.

НавітAт. Occasional in forest on volcanic islands; near sea level to $1600 \mathrm{~m}$ (in Samoa). (Highest elevation in Tonga is just over $1000 \mathrm{~m}$ ).

Collections. Kao: Buelow 613, 674. Tofua: Hotta 4355; Whistler 10598. Niuafo'ou: Whistler (sight record). Tafahi: Buelow 1151, 1297; ?Hurlimann 412; Whistler 6239.

\section{Phaius}

Lour., Fl. Cochinch.: 517. 1790.

Large terrestrial herbs with short, stout rhizomes and stems pseudobulbous or elongate and cane-like, leafy. Leaves pleated, large, not articulated. Inflorescence few- to many-flowered, racemose, axillary. Flowers usually large and often showy, resupinate, turning blue-black when damaged or with age; bracts persistent. 
Sepals and petals free, usually spreading, similar in shape and size. Lip shortly connate to column at the base, 3-lobed or entire, spurred at base, usually enclosing the column at the base; callus carinate. Column elongate, fleshy, lacking a foot or with a very short one; anther terminal; pollinia eight in two groups of four, clavate, waxy.

A genus of about 40 species in Africa, Madagascar, tropical Asia, the Malay Archipelago, and N.E. Australia eastward into the S.W. Pacific eastward to the Society Islands. One species naturalized in Hawai' $i$. One species is reported from Tonga, one from Tonga and the Cook Islands, and a third from Tonga, the Cook Islands, and Niue.

\section{Key to SPECIES}

1. Leaves borne in a cluster on pseudobulb; flowers somewhat nodding; sepals and petals chestnut with white backs; lip purple with a distinct spur, 6-8 mm long; bracts persistent

1. P. tankervilleae

1 Leaves borne laterally on pseudobulb; flowers spreading, not colored as above; lip lacking a distinct spur; bracts caducous or persistent

2. Flowers yellow with a whitish lip marked with purple and a yellow center; lip rhombic-elliptic with undulate apex; leaves borne along cylindrical pseudobulbs; lip with a short spur 2. P. robertsii

2. Flowers white, sometimes with a creamy lip; lip flabellate; stem elongate, non-pseudobulbous; lip lacking a spur

3. P. amboinensis

1. Phaius tankervilleae (Banks ex L'Herit.) Blume, Mus. Bot. 2: 177. 1856; as P.tankervilii. Type: China, cult. Kew (holotype BM!). For full synonymy, see Hallé (1977) and Kores (1991).

Large terrestrial herb up to $2 \mathrm{~m}$ in height, with conical to ovoid pseudobulbs $2.5-6 \times 2-5 \mathrm{~cm}$. Leaves narrowly elliptic to elliptic-lanceolate, acuminate, up to $120 \times 4-20 \mathrm{~cm}$; petiole up to $25 \mathrm{~cm}$ long. Inflorescence erect, laxly 10-20-flowered, 60-200 cm long; bracts persistent, lanceolate, 3-5 cm long. Flowers large, showy, the sepals and petals white to pale purple on outer side, yellow to brown within; lip white or yellowish in throat, heavily marked with purple especially towards the apex; pedicel and ovary $2.5-5 \mathrm{~cm}$ long. Sepals lanceolate to oblanceolate, acuminate, $4.5-6.5 \times 0.7-1.5 \mathrm{~cm}$. Petals similar to sepals. Lip trumpet-shaped, broadly obovate and obscurely 3-lobed when flattened, apiculate, $4-5.5 \mathrm{~cm}$ long; spur slightly recurved, $0.6-0.8 \mathrm{~cm}$ long. Column slightly clavate, $1.5-2 \mathrm{~cm}$ long. Fig. 33.

Distribution. Tonga ('Eua, Kao, Tofua, Vava'u, Late, Niuafo'ou, and Tafahi), the Cook Islands (Rarotonga and Mangaia), and Niue. Also widely distributed from Asia, S.E. Asia and the Malay Archipelago to New Guinea, New Caledonia, the Horne Islands, Fiji, and Australia. Probably a recent arrival in Polynesia and elsewhere in the Pacific islands.

НАвітAт. Occasional in foothill to montane forest and in fernlands; 200-700 m.

Collections. 'Eua: Parks 16255. Kao: Buelow 2813, 3181. Tofua: Hotta 4385, 4388; Whistler10621. Vava'u: Crosby 248. Late: Buelow \& Sykes 82, 222; Hotta 4799. Niuafo'ou: Buelow 2256. Tafahi: Buelow 1196, 1216; Whistler 6240. Rarotonga: Cheeseman 677; Philipson 10101; Sykes 2057, 2732; Whistler 5114; Wilder (published sight record). Mangaia: Sykes 576; Whistler 5452. Niue: Sykes 398, 473, 539, 600, 805 .

2. Phaius robertsii F. Muell., S. Sci. Rec. 3: 263. 1883. Type: New Caledonia, Layard s.n. (holotype MEL!).

Large terrestrial herb up to $90 \mathrm{~cm}$ in height, with cylindrical pseudobulbs, 5-8-leafed along length in upper part. Leaves elliptic, acuminate, 11-26 × 4-8 cm, green. Inflorescence erect, 50-90 cm long, laxly several- 
flowered; bracts persistent, $1.5-2.8 \mathrm{~cm}$ long. Flowers yellow, lip white with purple guide lines and yellowish in center; pedicel and ovary $1.4-2.5 \mathrm{~cm}$ long. Sepals lanceolate, acuminate, $2.3-2.5 \times 0.4-0.5 \mathrm{~cm}$; lateral sepals falcate. Petals similar to sepals. Lip connate for basal ca. $4 \mathrm{~mm}$ with the column, rhombic-orbicular, somewhat 3-lobed in front, 2.3-2.5 $\times 2-2.5 \mathrm{~cm}$, apical margins undulate-crispate; spur very shortly conical, 1-2 mm long. Column hairy on ventral surface, ca. $1.5 \mathrm{~cm}$ long. Fig. 34.

Distribution. Tonga (Tofua). Also in Vanuatu, New Caledonia, and Fiji. HaвiтAт. Uncommon in montane forest on crater rims; 440-500 m.

Collections. Tofua: Buelow 2619; Whistler 10599.

3. Phaius amboinensis Blume, Mus. Bot. 2: 180 (1852). Type: Ambon, Zippelius s.n. (lectotype, selected here, L!), .

Phaius graeffei Rchb. f., Seem., Fl. Vit.: 299. 1868, (repr. Xenia Orchid. 3: 30. 1881. Type: Samoa, Graeffe s.n. (holotype W!).

Phaius terrestris (L.) Ormerod (1998), Austral. Orchid Rev. 59: 14. 1994, excl. typ. et syn.

Large terrestrial herb up to $1 \mathrm{~m}$ in height with leafy, elongate, non-pseudobulbous stems up to $30 \mathrm{~cm}$ long. Leaves elliptic-lanceolate, acuminate, up to ca. $65 \times 4-9 \mathrm{~cm}$, petiolate. Inflorescence erect, axillary, 30-70 $\mathrm{cm}$ long, laxly 5-15-flowered; bracts obovate, 2.5-3.5 cm long, caducous. Flowers showy, white with a pale yellowish lip, turning blue when damaged, sometimes cleistogamous; pedicel and ovary 1.7-3 cm long. Sepals oblong-obovate, subacute, $2.8-3.5 \times 1-1.3 \mathrm{~cm}$. Petals oblanceolate, slightly falcate, rounded at apex, $2.8-3.3 \times$ $0.7-0.8 \mathrm{~cm}$. Lip embracing column, flabellate when flattened, 3-lobed at apex, 2.5-3 cm long and wide, lacking a spur, mealy-tomentose on the disc. Column clavate, 2-2.5 cm long. Fig. 35.

Distribution. Tonga (Kao and Tafahi) and the Cook Islands (Rarotonga). Also in Indonesia (Ambon), New Guinea, Bougainville, the Solomon Islands, Vanuatu, Samoa, the Cook Islands, and Fiji.

НАвітAт. Uncommon in lowland to montane forest; 50-800 m.

Collections. Kao: Buelow 722. Tafahi: Buelow 1161, 1196. Rarotonga: Sykes 1486; Wilder 846. Note. The misapplication of the name Phaius terrestris to this species is discussed by Garay (1997) in Harvard Papers in Botany 2,1: 47-49.

\section{Spathoglottis}

Blume, Bijdr. Fl. Ned. Ind. 1, 8: 400. 1825.

Medium-sized to large terrestrial herbs, with clustered, pseudobulbous stems hidden by leaf bases. Leaves several, suberect to spreading, pleated. Inflorescence basal, axillary, erect, laxly to densely several- to manyflowered; bracts persistent. Flowers showy, white, yellow, pink, or purple, often with a yellow callus on lip. Sepals subsimilar, free, spreading widely. Petals similar, often slightly smaller than the sepals. Lip 3-lobed at base, lacking a spur, with a callus; side lobes upcurved-erect, smaller than midlobe; midlobe linear, spathulate or obovate; callus between lateral lobes, entire or bilobed, glabrous or hairy. Column clavate, lacking a foot; pollinia eight, pear-shaped.

A genus of about 40 species widespread in tropical and subtropical Asia, S.E. Asia, the Malay Archipelago, New Guinea, the Philippines, N.E. Australia and the western Pacific islands. A single species, Spathoglottis plicata, has been found in Tonga, Niue, and the Cook Islands, and occurs as an escape in many parts of the tropics, including Hawai' $i$ and Kenya.

Spathoglottis plicata Blume, Bijdr. Fl. Ned. Ind.: 401. 1825. Type: Java, Blume s.n. (holotype L!, isotype P!). 
Bletia angustifolia Gaudich., Voy. Uranie: 421. 1829. Type: Moluccas, Freycinet s.n. (holotype P!). Spathoglottis angustifolia (Gaudich.) Benth. \& Hook. f., Gen. Pl. 3: 512.1883.

Spathoglottis daenikeri Kraenzl., Vierteljahrsschhr. Naturf. Ges. Zürich 74: 80. 1929. Type: New Caledonia, Daeniker 1622 (holotype Z!).

Spathoglottis pacifica sensu Kraenzl., Bot. Jahrb. Syst. 25: 603. 1898; H. Fleischm. \& Rech., Denkschr. Kaiserl. Akad. Wiss., Wien. Math.-Naturwiss. Kl. 85: 257 (1910); Christoph., Bernice P. Bishop Mus. Bull. 128: 66 (1935), non Rchb. f.

Spathoglottis unguiculata auct., non (Labill.) Rchb. f. 1868.

Spathoglottis vieillardii Rchb. f., Linnaea 41: 85. 1877. Type: New Caledonia, Vieillard 1302 (holotype P!).

Large terrestrial herb up to $100 \mathrm{~cm}$ in height, with small ovoid pseudobulbs hidden by leaf bases. Leaves lanceolate to elliptic-lanceolate, acuminate, $40-90 \times 2-6 \mathrm{~cm}$, petiolate. Inflorescence erect, up to $1 \mathrm{~m}$ long, densely many-flowered; bracts elliptic-lanceolate, acuminate, $0.8-1.5 \mathrm{~cm}$ long. Flowers showy, purple, pink, or white with a yellow callus on the lip, pubescent on outer surface of sepals and petals; pedicel and ovary $3-5 \mathrm{~cm}$ long, densely shortly pubescent. Sepals elliptic to ovate, subacute to obtuse, 1.6-3 $\times 1-1.3 \mathrm{~cm}$; laterals slightly oblique. Petals elliptic, obtuse, 2-3 × 1.3-1.8 cm. Lip 3-lobed at base, T-shaped when flattened; side lobes narrowly oblong, 0.7$0.8 \mathrm{~cm}$ long; midlobe spathulate, $1-1.3 \mathrm{~cm}$ long, auriculate at base, with a small callus on claw; callus between side lobes bilobulate, glabrous or sparsely hairy. Column clavate, incurved, 1.2-1.3 cm long. Fig. 36.

Distribution. Tonga ('Eua, Tongatapu, Kao, Tofua, Vava'u, Late, Niuafo'ou, and Tafahi), the Cook Islands (Rarotonga), and Niue. Also widely distributed from Asia, S.E. Asia and the Malay Archipelago to New Guinea, the Solomon Islands, Vanuatu, New Caledonia, the Horne Islands, and Samoa. Naturalized in Hawai' $i$ and the Marquesas Islands.

НАвітAт. Occasional in disturbed places and open areas; near sea level to perhaps $1000 \mathrm{~m}$.

Collections. 'Eua: Hotta 5248 (cf. 5243), 5333a; Hurlimann 223; Lister s.n.; Sykes 511, 552, 553; Whistler 6472, 7422; Yuncker 15437. Tongatapu: USEE s.n., Graeffe s.n. Kao: Yuncker 15929. Tofua: Hotta 4375, 4387; Scarth-Johnson 27. Vava'u: Crosby 247. Late: Buelow \& Sykes 215; Hotta 4472, 4811. Niuafo'ou: Buelow 2070; Whistler 6430. Tafahi: Buelow 1185; Hurlimann 431; Whistler 6241. Rarotonga: Sykes 1548, 2008, 2512; Whistler 5104. Niue: Sykes 150584; Whistler 10753; Yuncker 9619.

\section{ACANTEPHIPPIUM}

Blume, Bijdr. Fl. Ned. Ind. 353, t. 47. 1825.

Large terrestrial herbs with large green, ovoid-conical to conical-cylindrical clustered pseudobulbs. Leaves 2-3, suberect, plicate, slenderly petiolate. Inflorescence lateral from the base of the pseudobulbs, erect, 1-7-flowered, shorter than the leaves; bracts lanceolate, large. Flowers large, urn-shaped or campanulate, fleshy. Dorsal sepal free. Lateral sepals forming a distinct saccate mentum with the column-foot. Petals free but enclosed within the sepals. Lip saddle-shaped, 3-lobed, callose, lacking a spur, articulated to the columnfoot. Column short, fleshy with a distinct foot; pollinia eight, clavate.

A genus of about 16 species in S.E. Asia, the Malaya Archipelago, the Philippines and S.W. Pacific islands. A single species is reported in Tonga.

Acanthephippium splendidum J.J. Sm., Natuurk. Tijdschr. Ned.-Indië 58: 360 (1898). Type: Hort. Bogor. 328c (holotype L!). 
Acanthephippium papuanum Schltr., Repert. Spec. Nov. Regni Veg. Beih. 1: 371. 1912. Type from New Guinea.

Terrestrial herb up to $80 \mathrm{~cm}$ in height, with ovoid-conical to conical-cylindrical, 3-noded, green pseudobulbs 6-12 × 2.5-5 cm, 2-3-leafed. Leaves suberect, plicate, elliptic, acute, 25-45 × 10-15 cm; petiole slender, up to $25 \mathrm{~cm}$ long. Inflorescence erect, 1-7-flowered, 10-15 cm long; bracts lanceolate, up to $2.5 \mathrm{~cm}$ long. Flowers urn-shaped, sepals white to yellowish creamy, striped with pink or reddish, petals and lip pale yellow. Dorsal sepal oblong-lanceolate, 3.5-4 × 1-1.2 cm. Lateral sepals obliquely oblong-ovate, 3.5-4 × 1.2-1.5 $\mathrm{cm}$; mentum sub-gibbose at apex, 0.7-1.4 cm long. Petals rhombic, obtuse, 3.1-3.9 × 1.6-2.2 cm. Lip 3-lobed, $1.5-1.8 \times 1.2-1.6 \mathrm{~cm}$; side lobes erect; midlobe oblong to oblong-spathulate; callus of 3-5 longitudinal keels. Column ca. $1.5 \mathrm{~cm}$ long, foot incurved, ca. $2.8 \mathrm{~cm}$ long. Fig. 37.

Distribution. Tonga (Kao, Tofua, and Tafahi). Also in Sulawesi, New Guinea, the Solomon Islands, Vanuatu, Fiji, and New Caledonia (and newly discovered in Samoa).

НавітAт. Uncommon in lowland to foothill forests; 150-400 m.

Collections. Kao: Buelow 2956. Tofua: Buelow 2543, 2655. Tafahi: Buelow 1262; Hurlimann 439.

\section{LIPARIS}

L.C. Rich., De Orchid. Eur.: 21, 30, 38. 1817;

Mém. Mus. Hist. Nat. Paris 4: 43, 52, 60. 1818.

Small to medium-sized, terrestrial, lithophytic, or epiphytic herbs with short to long, leafy, pseudobulbous stems covered when young by sterile bracts. Leaves one to several, linear to ovate or elliptic, pleated or not, thin-textured to somewhat coriaceous. Inflorescence terminal, erect, racemose, few- to many-flowered. Flowers usually small, yellow, green, orange, or purple, often somewhat translucent, resupinate. Sepals free, spreading; laterals sometimes fused for part or all of length. Petals free, often linear and unlike sepals, often reflexed. Lip often strongly reflexed, ovate, oblong or flabellate, entire or lobed, usually with a basal callus, lacking a spur. Column incurved, clavate, elongate; pollinia four in two pairs.

A large cosmopolitan genus of some 350 species well represented in tropical Asia, the Malay Archipelago, the Philippines, New Guinea, Australia, and the S.W. Pacific islands, with three species in Tonga and one in the Cook Islands.

\section{Key to SpeCies}

1. Leaf solitary, heart-shaped

1. L. clypeolum

1. Leaves 2 or more, ovate to lanceolate or oblanceolate

2. Blades ovate; flowers purple with a green column

2. L. layardii

2. Blades lanceolate or oblanceolate; flowers mostly yellowish green

3 . Leaves 2 , not distinctly plicate; articulate above base

3. L. elegans

3. Leaves 3 or more, distinctly plicate, not articulate

4. L. disepala

1. Liparis clypeolum (Forst. f.) Lindl., Gen. Sp. Orchid. Pl.: 23. 1830. Type: Tahiti, Forster s.n. (lectotype K!).

Cymbidium clypeolum (Forst. f. ) Willd., Sp. Pl. 4: 22. 1804.

Epidendrum clypeolum Forst. f., F1. Ins. Austr.: 61. 1786.

Terrestrial herb $15-25 \mathrm{~cm}$ in height, with one-leafed, approximate, ovoid-ellipsoidal pseudobulbs 2-3 $\times$ 1-1.5 cm. Leaf heart-shaped, acute, 7-18.5 × 6-13.5 cm, long-petiolate; petiole 5-9 cm long. Inflorescence 
erect, densely 10-20-flowered, racemose to subcapitate; bracts linear-lanceolate, acuminate, 3-10 mm long. Flowers whitish; pedicel and ovary 17-23 mm long. Dorsal sepal lanceolate, subacute, ca. $10 \mathrm{~mm}$ long. Lateral sepals triangular-lanceolate, obtuse, ca. $10 \mathrm{~mm}$ long. Petals linear, subacute, ca. $10 \mathrm{~mm}$ long. Lip broadly obovate, apiculate, ca. $10 \times 8 \mathrm{~mm}$, with a serrulate margin; basal callus very small. Column a little dilated at the base, semi-terete above, ca. $4 \mathrm{~mm}$ long. Fig. 38 .

Distribution. Cook Islands (Rarotonga). Also in the Society and Marquesas Islands.

HABIтAT. Rare in shaded mossy montane forest; 300-650 m.

Collections. Rarotonga: Cheeseman s.n., 676.

2. Liparis layardii F. Muell., S. Sci. Rec., n.s., 1: 1. 1885. Type: New Caledonia, Layard s.n. (holotype MEL!).

Liparis mataanensis J.J. Sm., Bull. Jard. Bot. Buitenzorg, II, 8: 56. 1912. Type: As for L. stricta. Liparis stricta Schltr., Repert. Spec. Nov. Regni Veg. 9: 95. 1910. Type: Samoa, Vaupel 134 (lectotype $\mathrm{B} \dagger$, isotype $\mathrm{K}$ !).

Liparis sp. 1 sensu Kraenzl., Bot. Jahrb. Syst. 25: 601. 1898.

Terrestrial herb, erect, up to $45 \mathrm{~cm}$ in height, with clustered, 2-3-leafed, cylindrical pseudobulbs up to $20 \times 1 \mathrm{~cm}$. Leaves ovate to ovate-elliptic, acute, $6.5-10 \times 5-7 \mathrm{~cm}$; petiole $2-3.5 \mathrm{~cm}$ long. Inflorescence laxly 8-15-flowered, 12-30 cm long; bracts 5-10 mm long. Flowers purple with a green column; pedicel and ovary 1-1.2 cm long, 6-angled. Dorsal sepal erect, oblong-lanceolate, acute, 7-12 × 2-2.5 mm. Lateral sepals reflexed, oblong to oblong-ovate, obtuse, $6.5-10 \times 2.5-3 \mathrm{~mm}$. Petals linear-ligulate, subacute, $6-12 \times$ $0.75-1.25 \mathrm{~mm}$. Lip recurved, flabellate to obovate, $6.5-10 \times 5.5-7.5 \mathrm{~mm}$, the margins weakly crenulate; callus bilobulate, basal. Column incurved at apex, 5-6 mm long. Fig. 39.

Distribution. Tonga (Kao and Tofua). Also in the Solomon Islands, Vanuatu, New Caledonia, Samoa, and Fiji.

Habitat. Occasional in montane forest; perhaps up to $1000 \mathrm{~m}$ in these islands.

Collections. Kao: Buelow 713; Whistler 10713. Tofua: Buelow 2547; Whistler 10600.

3. Liparis elegans Lindl., Gen. Sp. Orchid. P1.: 30. 1830. Type: Malaya, Penang, Wallich s.n. (holotype K!).

Cestichis gracilis (Hook. f.) Ames, Orchidaceae 2: 136. 1908.

Leptorkis elegans (Lindl.) Kuntze, Revis. Gen. P1. 2: 671. 1891.

Leptorkis gracilis (Hook. f.) Kuntze, Revis. Gen. P1. 2: 671. 1891.

Liparis gracilis Hook. f., Hooker's Icon. P1. 21: t. 2011. 1889. Type: Malaya, Perak, Wray s.n. (holotype $\mathrm{K}$ !).

Epiphytic herb 15-35 cm in height, with slender pseudobulbs 1-3 × 0.8-1.5 cm, two-leafed towards the apex. Leaves suberect, linear-oblanceolate, acute, $11-25 \times 1.5-3 \mathrm{~cm}$, articulate above base. Inflorescence 14-35 cm long, laxly many-flowered; rachis 5-15 cm long; bracts lanceolate, acuminate, 4-6 mm long. Flowers small, probably self-pollinating, pale yellowish green; pedicel and ovary 3-5 mm long. Dorsal sepal reflexed, oblong, obtuse, 3.5-4 $\times 1.2-1.7 \mathrm{~mm}$. Lateral sepals reflexed, elliptic, obtuse, 3.5-4 × 1.2-2 mm. Petals linear, obtuse, 3.5-4 × 0.4-0.7 $\mathrm{mm}$. Lip obscurely 3-lobed, 3.5-4 × 1.5-2 mm, geniculate in middle; side lobes erect, narrowly oblong; midlobe oblong or elliptic-oblong, retuse; callus basal, obscurely bilobed. Column incurved at apex, 2-5 mm long. Fig. 40.

Distribution. Tonga (Kao, Tofua, and Tafahi). Also occurring from S.E. Asia into Malesia, and eastwards to the Solomon Islands, Vanuatu, New Caledonia, Samoa, and Fiji.

HАвітат. Occasional in coastal to montane forest; near sea level to $700 \mathrm{~m}$. 

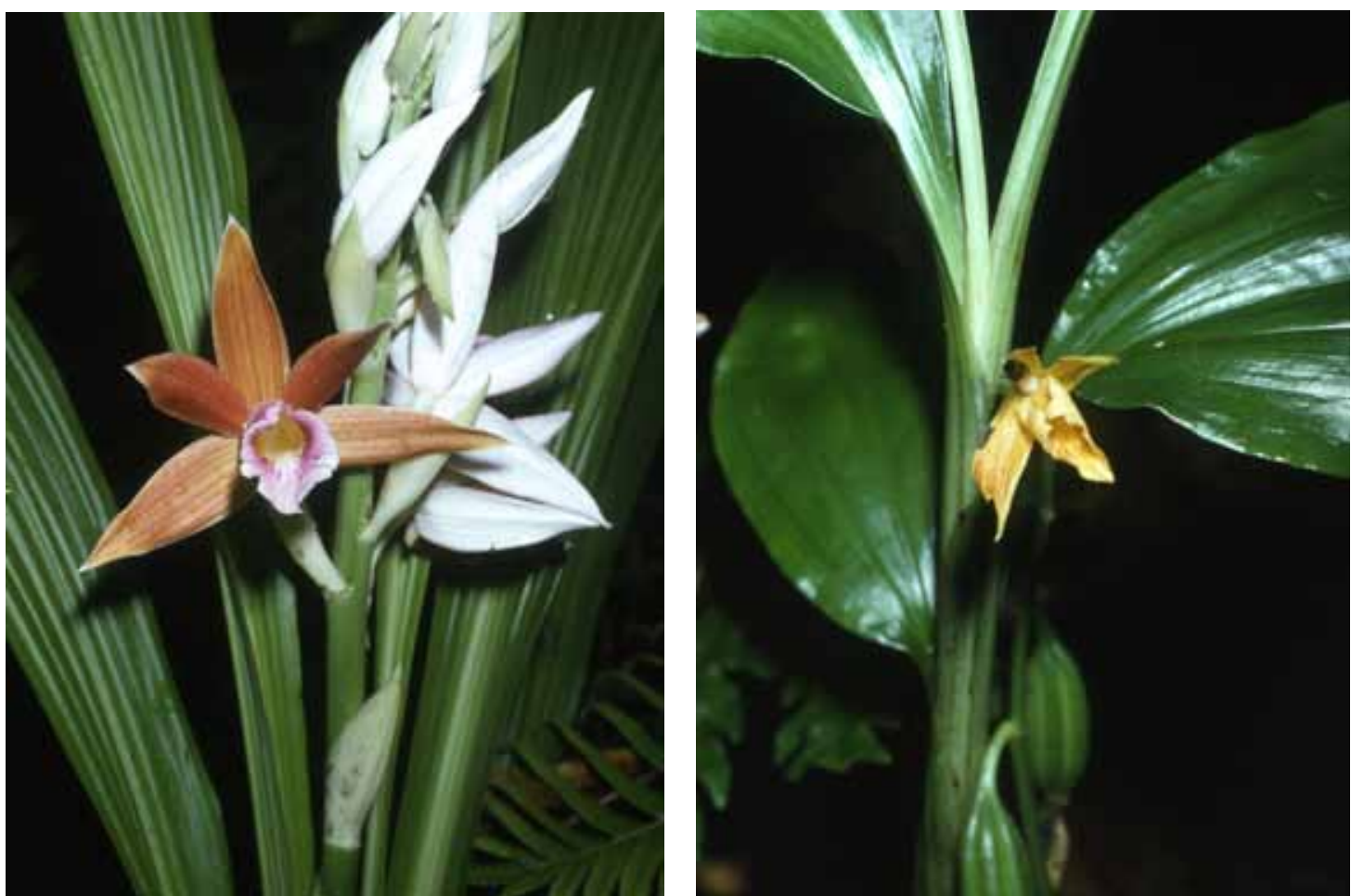

FIGURE 33. Phaius tankervillae. Tonga.

FIgURE 34. Phaius robertsii. Tonga.

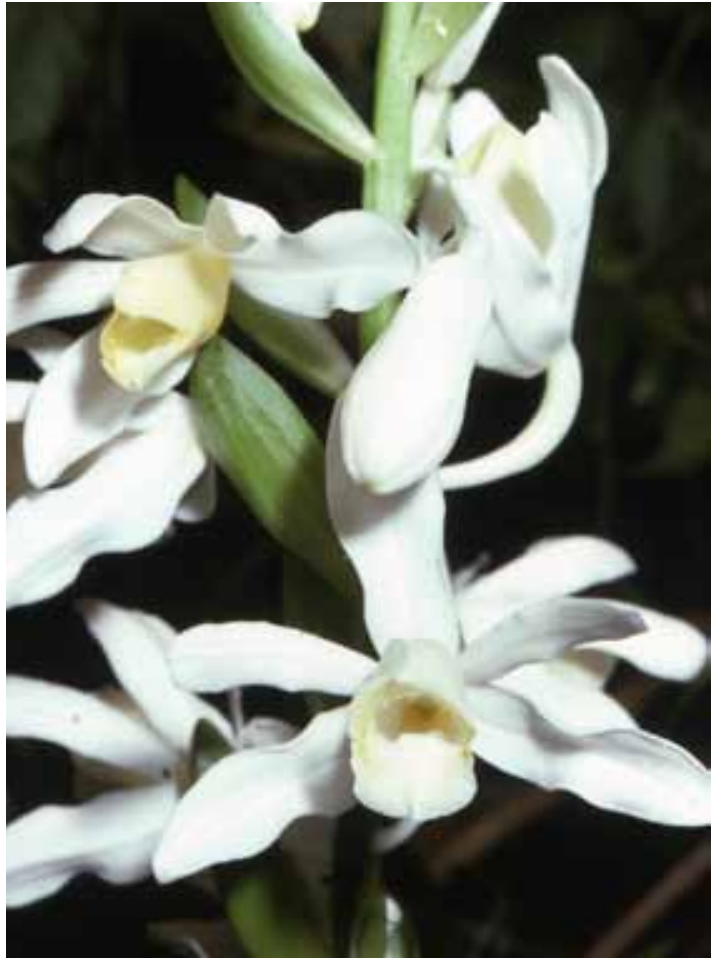

FIgURE 35. Phaius amboinensis. Samoa.

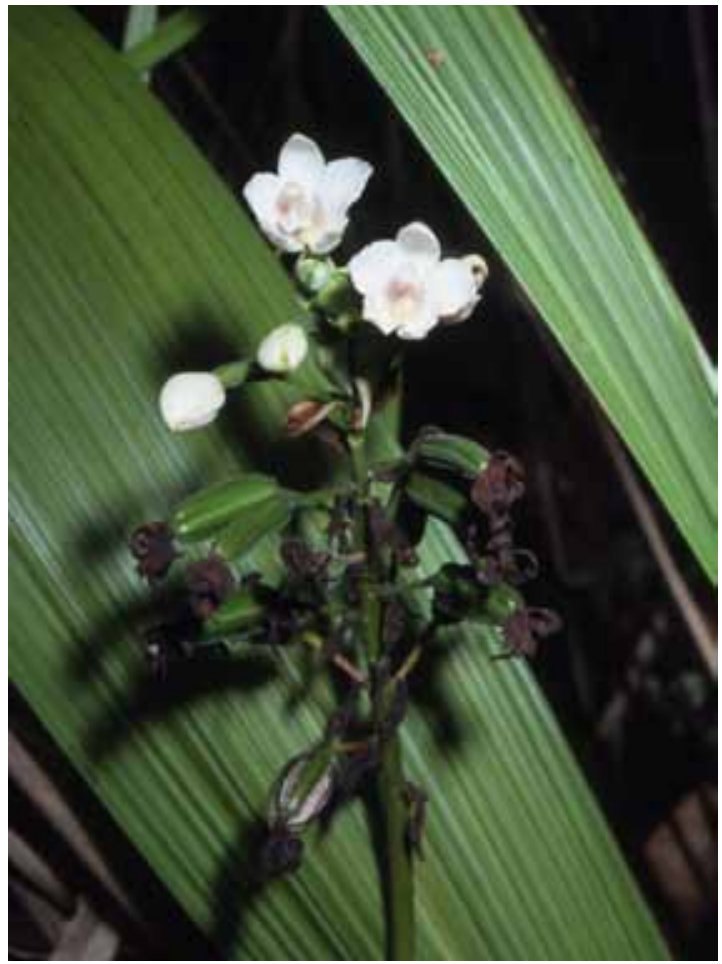

FIGURE 36. Spathoglottis plicata. Tonga.

LANKESTERIANA 11(2), August 2011. (C) Universidad de Costa Rica, 2011. 


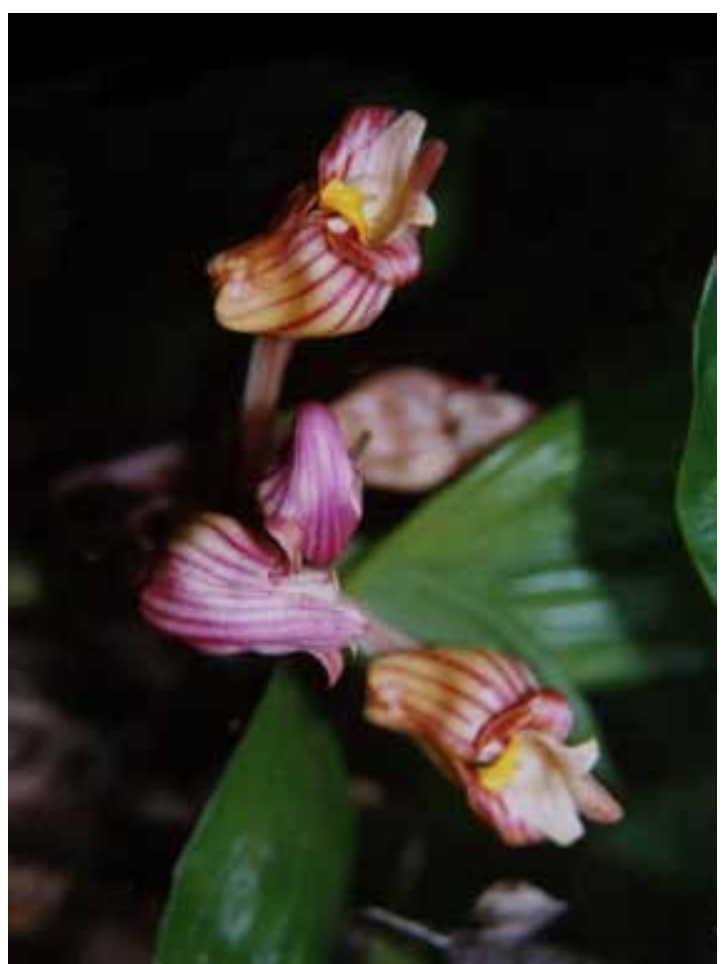

FigURE 37. Acanthephippium splendidum. Samoa.

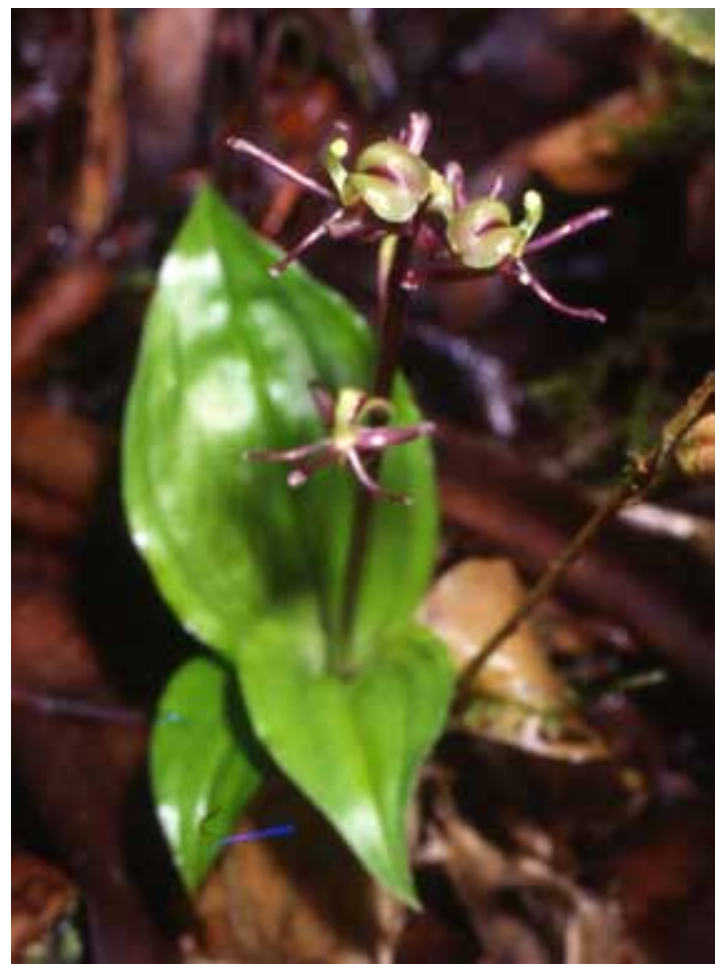

FIGURE 39. Liparis layardii. Samoa.

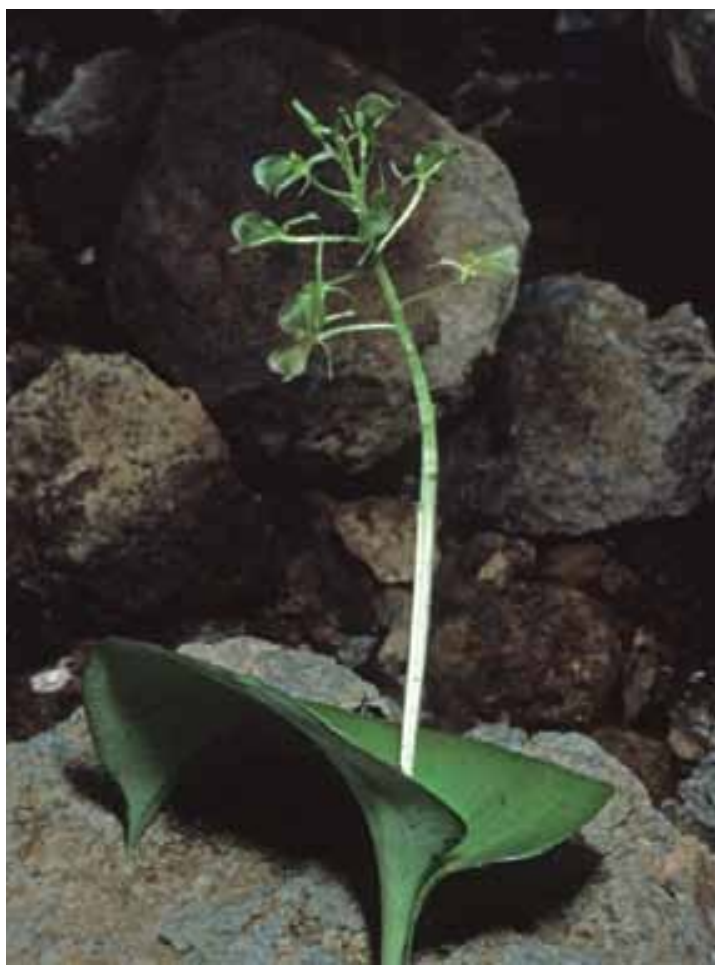

FIGURE 38. Liparis clypeolum. Marquesas.

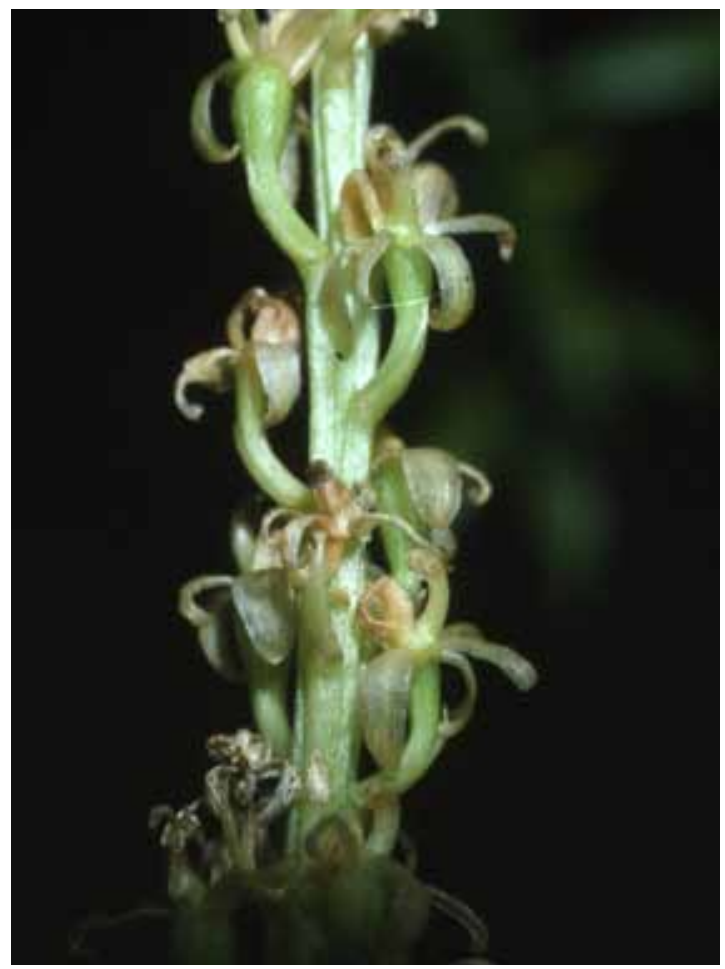

FigURE 40. Liparis elegans. Tonga. 

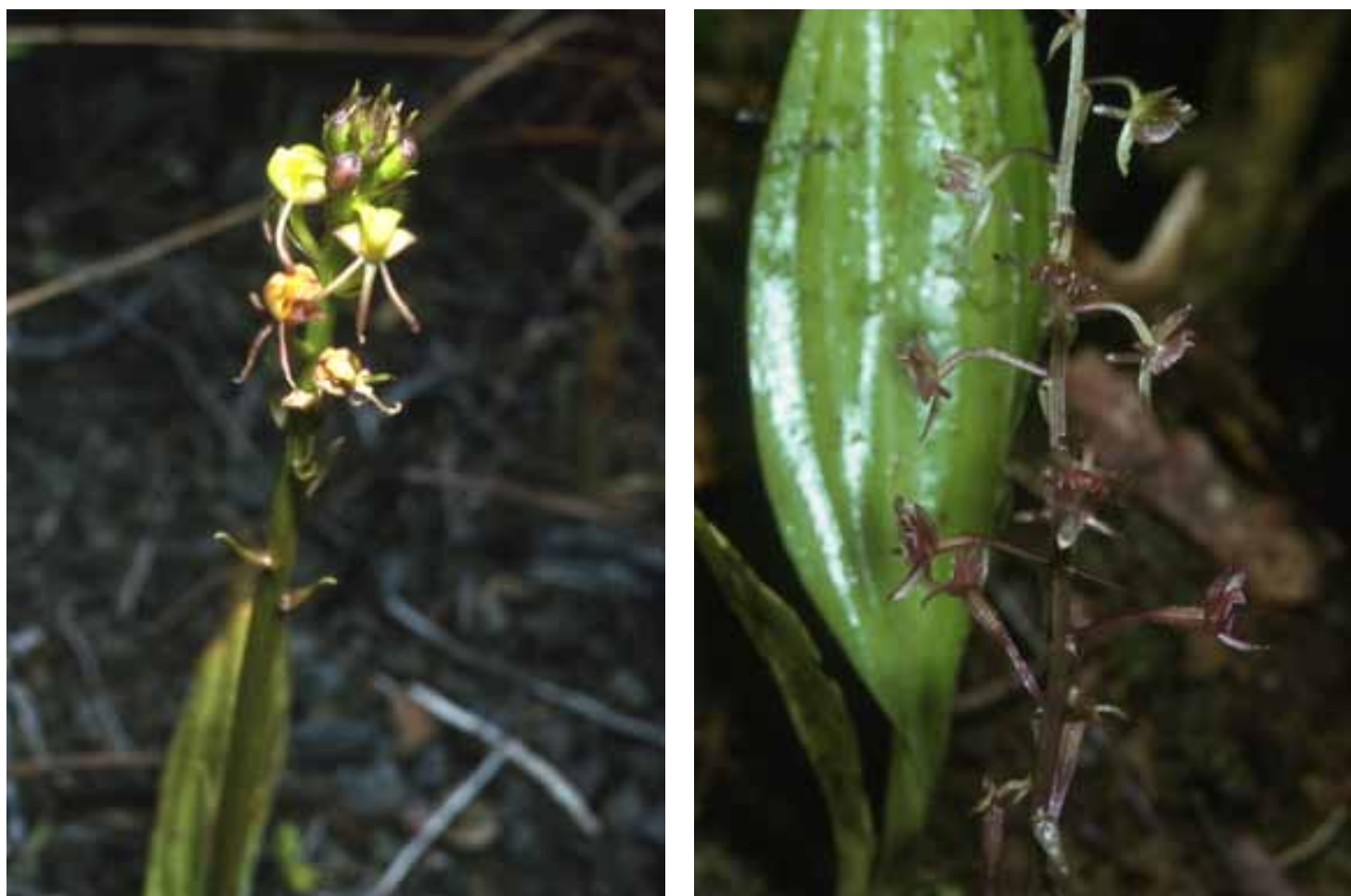

FIGURE 41. Liparis disepala. Tonga.

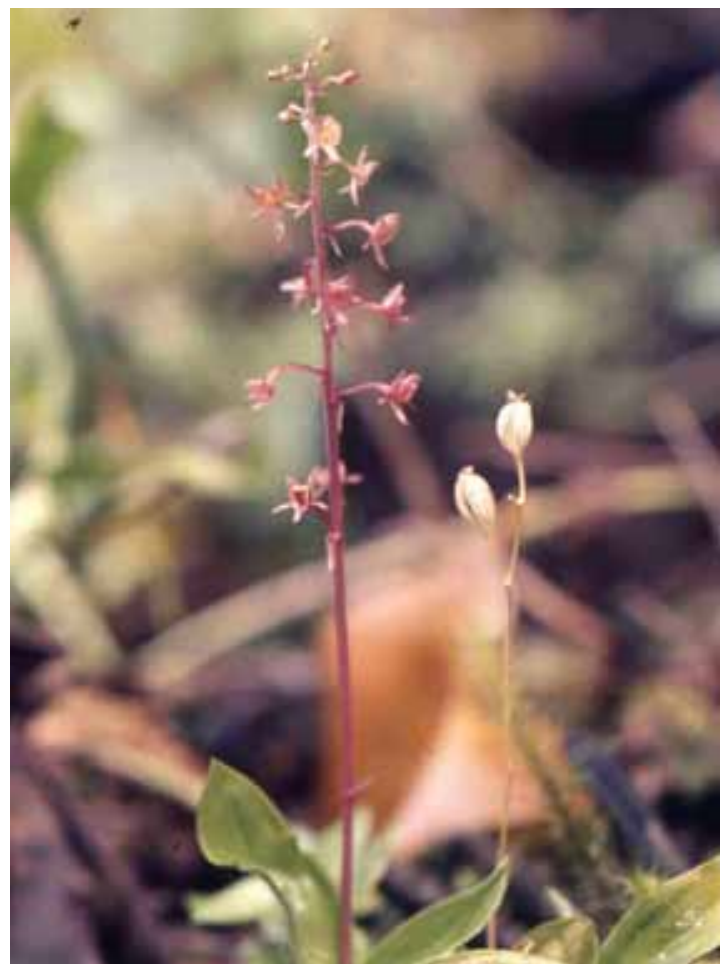

FIGURE 43. Crepidium taurinum. Samoa.

FIGURE 42. Crepidium resupinatum. Cooks.

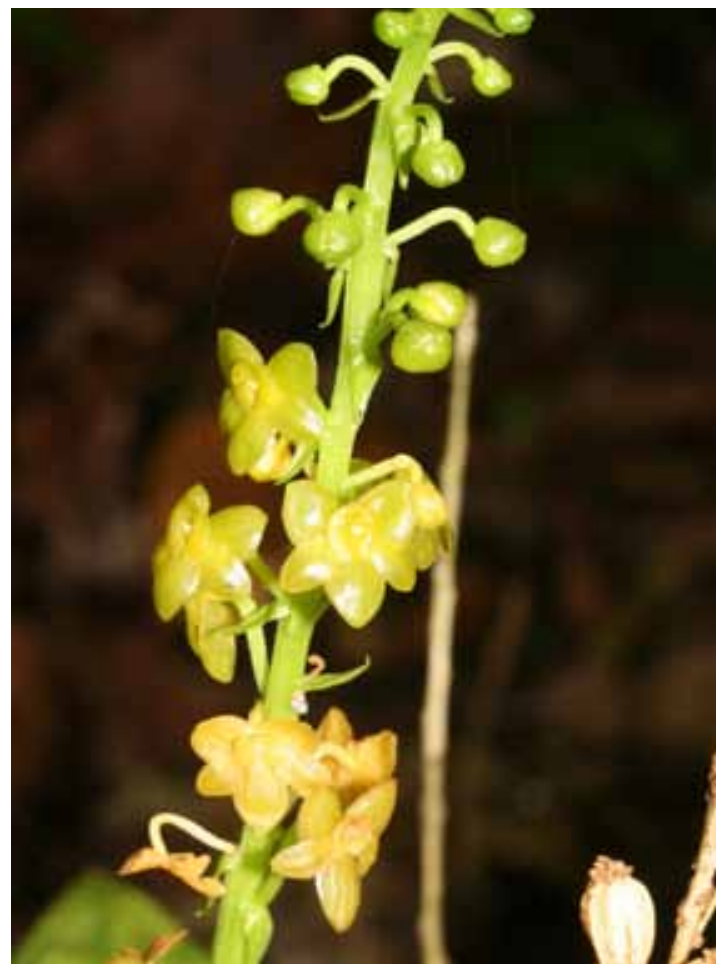

FIgURE 44. Crepidium latisegmentum. Eua.

LANKESTERIANA 11(2), August 2011. (C) Universidad de Costa Rica, 2011. 


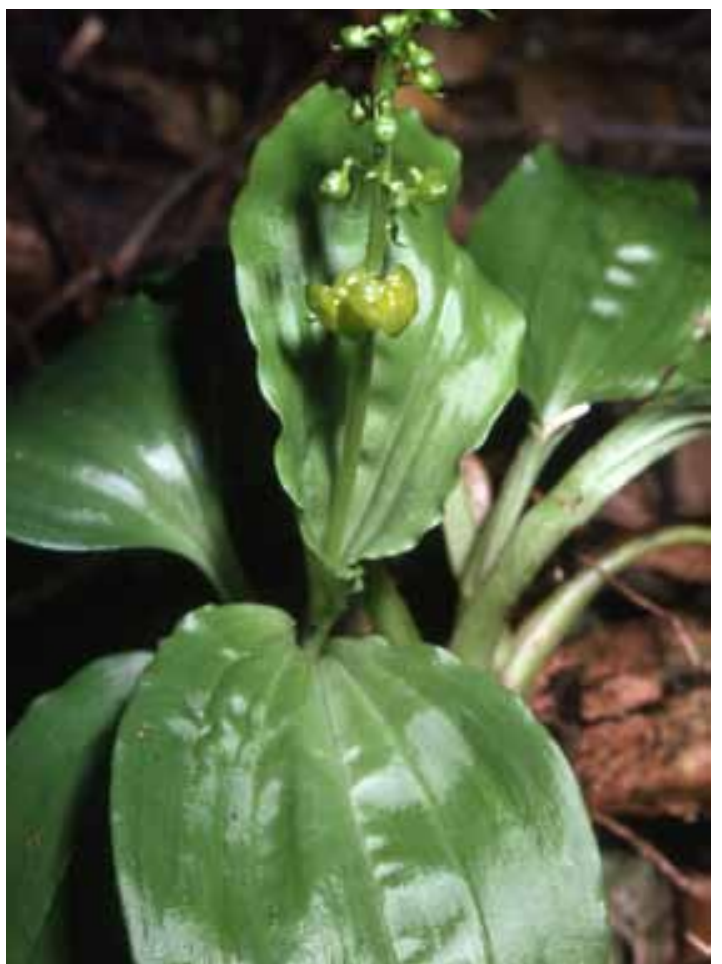

FiguRE 45. Crepidium brevidentatum. Tonga.

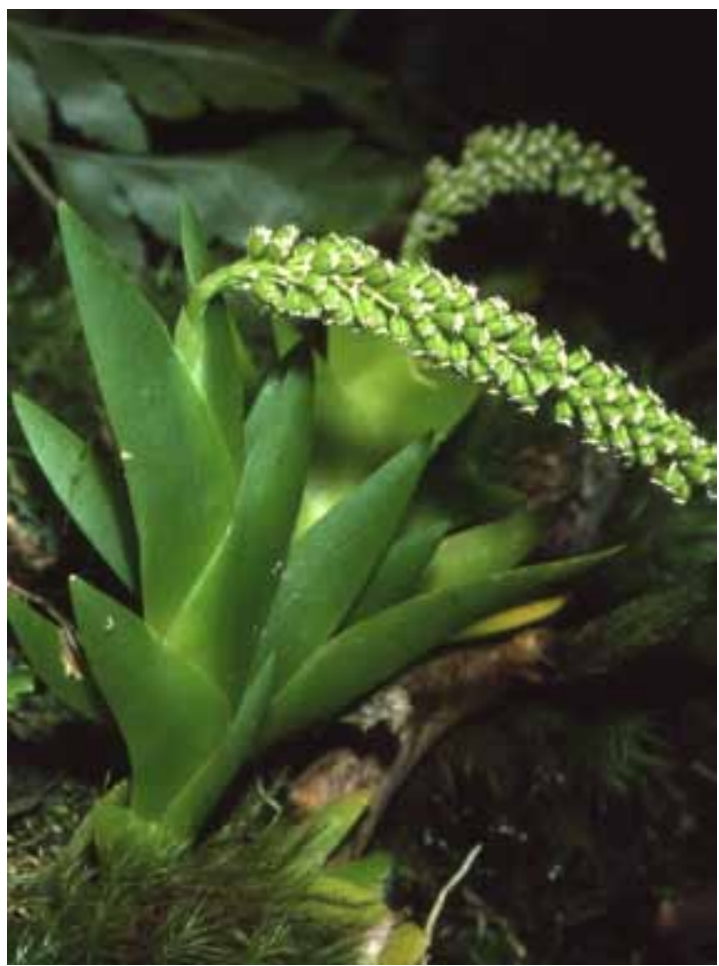

FIGURE 47. Oberonia equitans. Cooks.

LANKESTERIANA 11(2), August 2011. (C) Universidad de Costa Rica, 2011.

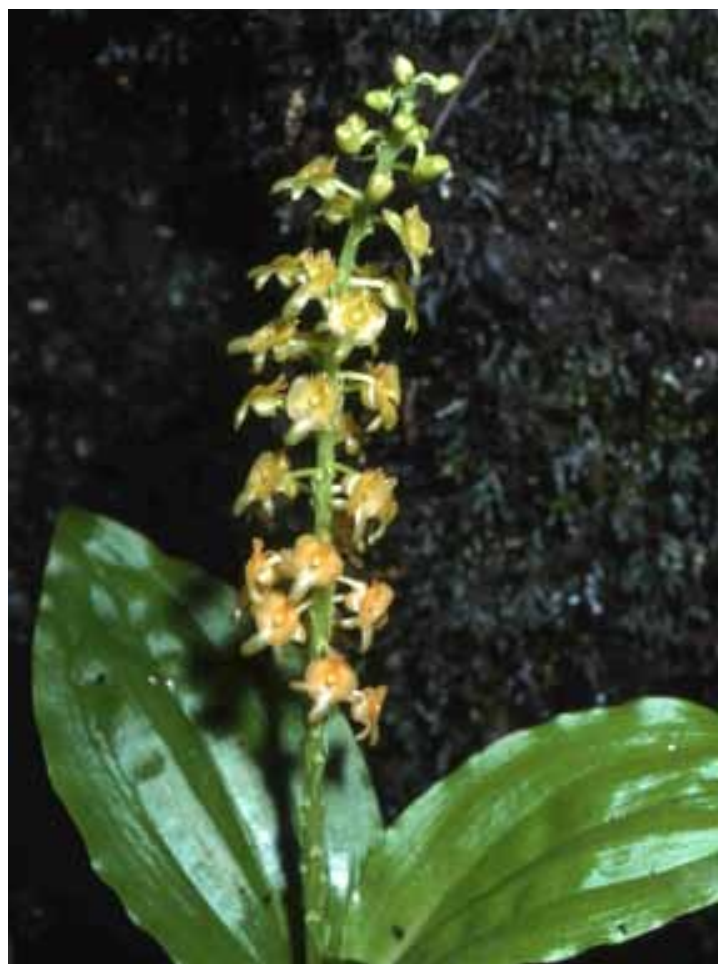

Figure 46. Crepidium reineckeanum. Samoa.

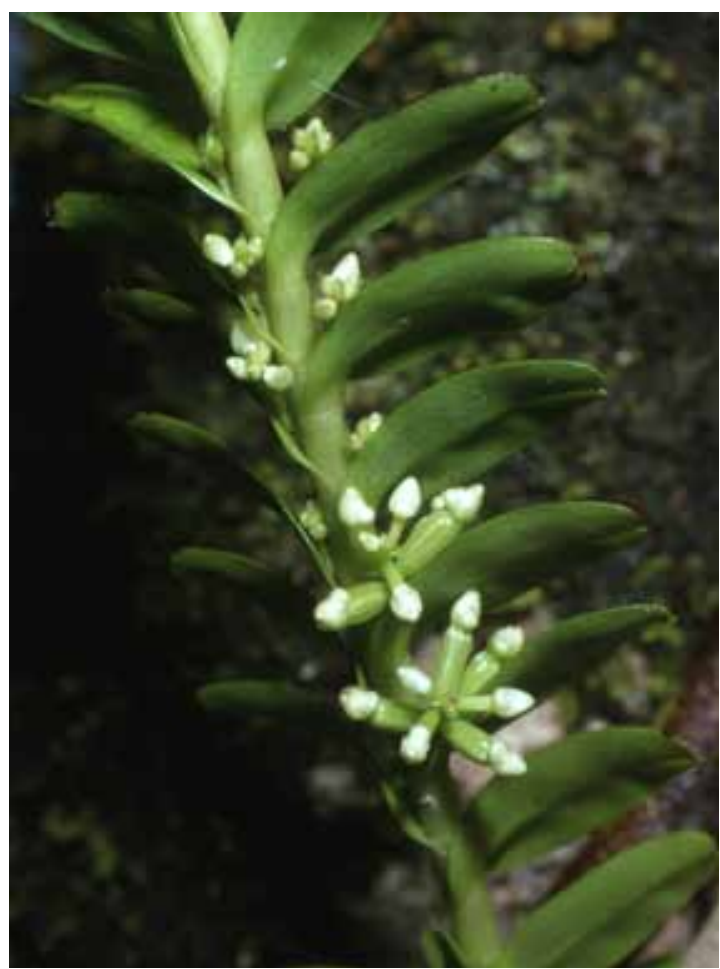

Figure 48. Appendicula reflexa. Tonga. 
Collections. Kao: Buelow 617, 2910; Whistler 10721. Tofua: Buelow 549, 2548, 2558; Hotta 4407; Whistler 10606. Tafahi: Whistler 6242.

4. Liparis disepala Rchb. f., Linnaea 41: 97. 1877. Types: New Caledonia, Deplanche 150, 355 (syntypes P); Vieillard 1320 (syntype P).

Terrestrial herb $20-48 \mathrm{~cm}$ in height, with ovoid pseudobulbs 1-3.5 $\times 0.6-2.5 \mathrm{~cm}$. Leaves non-articulate, 4 or 5, suberect, lanceolate, clasping at base, 12-29 $\times 1-3.5 \mathrm{~cm}$; petiole $4.5-9 \mathrm{~cm}$ long. Inflorescence a terminal, bracteate raceme $15-30 \mathrm{~cm}$ long, subdensely 6-30-flowered. Flowers green to greenish yellow with red to yellowish brown markings. Dorsal sepal oblong-lanceolate, 7-8 $\times 1.2-1.8 \mathrm{~cm}$. Lateral sepals reflexed, ovatefalcate, 4.5-6 $\times 2-3 \mathrm{~cm}$. Petals reflexed, linear-oblanceolate, 6-7 $\times 1-1.25 \mathrm{~cm}$. Lip prominently arcuate, oblong-obovate, $3.5-5 \times 3-4.5 \mathrm{~cm}$, with entire margins, retuse at apex; callus transverse, obscurely trilobulate. Column slightly curved, $3-3.5 \mathrm{~cm}$ long. Fig. 41.

Distribution. Tonga ('Eua, Kao, Tofua, and Late). Also in New Caledonia and Fiji.

HавітAт. Occasional in fernlands; ca. $60 \mathrm{~m}$.

Collections. 'Eua: Hotta 5246; Sykes 246, 334a; Whistler 7147, 7282, 7457; Yuncker 15446. Kao: Whistler 10691. Tofua: Buelow 437!, 2584; Whistler 10614. Late: Hotta 4800.

\section{CREPIDIUM}

Blume, Bijdr. Fl. Ned. Ind. 387. 1825.

Terrestrial or rarely epiphytic herbs with hairy roots. Stems cylindrical to pseudobulbous, fleshy, leafy. Leaves several, thin-textured to fleshy, pleated, petiolate; petiole sheathing at base. Inflorescence apical, erect, racemose, laxly to densely few- to many-flowered. Flowers small, green, brown, yellow, pink, or purple, nonresupinate. Dorsal sepal spreading free. Lateral sepals free or fused, spreading. Petals often narrower than sepals, free, spreading. Lip erect, flat but sometimes concave at base, entire to lobed, auriculate at base, apical margins often toothed, lacking a spur, callus absent or obscurely ridged. Column very short, lacking a foot; pollinia 4, waxy, lacking appendages.

This genus has recently been resurrected as a segregate of Malaxis Sol. ex Sw. Crepidium comprises about 130 species found throughout the Old World tropics and subtropics. Three species are reported from Tonga, one from the Cook Islands, and one from Tonga, the Cook Islands, and Niue. The regional taxonomy is in urgent need of revision.

\section{Key to SPECIES}

1. Leaves 3-5, clustered more or less at base of plant; lip midlobe bifid; apical margins of side lobes strongly denticulate

1. C. resupinatum

1. Leaves 3-7 or more arranged along the elongate erect stem; lip midlobe entire or emarginate; apical margins of side lobes entire to weakly denticulate

2. Leaves narrowly ovate, twice as long as broad; flowers purple or pale yellow; lip longer than broad; side lobes acute but not toothed in front

2. C. taurinum

2. Leaves broadly ovate, less than twice as long as broad; flowers pale yellow; lip broader than long, entire or with the side lobes with several teeth along front margin

3. Lip with apical margins entire

3. C. latisegmentum

3. Lip with toothed apical margins

4. Apical teeth of lip rather obscure

4. C. brevidentatum

4. Apical teeth of lip strongly developed

5. C. reineckeanum 
1. Crepidium resupinatum (Forst. f.) Szlach., Fragm. Florist. Geobot., Suppl. 3: 131. 1995. Type: Tahiti, Forster s.n. (holotype BM!).

Epidendrum resupinatum Forst. f., Fl. Ins. Austr. Prodr.: 61. 1786.

Malaxis resupinata (Forst. f.) Kuntze, Revis. Gen. P1. 2: 673.1891.

Microstylis resupinata (Forst. f.) Drake, Ill. Fl. Ins. Pacif.: 305. 1892.

Terrestrial plant with decumbent or ascending terete stems 5-10 cm long, 3-5-leaved. Leaves erect or ascending, obliquely oblong-elliptic or ovate-elliptic, acuminate, 10-22 $\times 4.5-8 \mathrm{~cm}$; petiole relatively stout, 6-10.5 cm long, somewhat dilated and sheathing at base. Inflorescence erect, $21-45 \mathrm{~cm}$ long, laxly manyflowered; peduncle weakly angular, 15-25 cm long; bracts lanceolate, acuminate, $2.5-5 \mathrm{~mm}$ long. Flowers maroon; pedicel and ovary ca. $6 \mathrm{~mm}$ long. Dorsal sepal oblong to oblong-elliptic, subacute, 3.5-4.5 × 1-1.5 $\mathrm{mm}$. Lateral sepals falcate, oblong, obtuse, 3-4 mm long, ca. $1.5 \mathrm{~mm}$. Petals slightly falcate, linear-ligulate, subacute, 3.5-4 × 0.7-0.8 mm wide. Lip more or less oblong-obovate, prominently auriculate at base, weakly 3-lobed in front, 5-6 $\times 4-5 \mathrm{~mm}$; side lobes broadly rounded with several short teeth on front margin; midlobe small, semi-orbicular, acutely bilobed; callus horseshoe-shaped. Column $0.5-1 \mathrm{~mm}$ long. Fig. 42.

Distribution. Tonga ('Eua, Tofua, Late, Niuafo'ou, and Tafahi), the Cook Islands (Rarotonga and Mangaia ), and Niue. Also widely distributed in the South Pacific, Vanuatu, Fiji, Samoa, and the Society Islands.

Habitat. Common in lowland and montane forest; near sea level to $500 \mathrm{~m}$.

Collections. 'Eua: Hotta 5508, 5559; Parks 16313; Sykes 320, 413; Whistler 7113, 7294; Yuncker 15575. Tofua: Buelow 482. Late: Hotta 4807. Niuafo'ou: Buelow 2068, 2141; Whistler 6323. Tafahi: Buelow 1158, 1189; Whistler 6246. Rarotonga: Cheeseman s.n.; Luttrell 351, 357; Parks 22039, 22126; Philipson 10128, 10342; Seale s.n.; Sykes 75, 1462; Whistler 4041, 5045, 5197. Mangaia: Sykes 561; Whistler 5468. Niue: Sykes 397, 537, 629; Whistler 10741.

2. Crepidium taurinum (Rchb. f.) Szlach., Fragm. Florist. Geobot., Suppl. 3: 132 1995. Type: New Caledonia, Deplanche s.n. (holotype, W).

Malaxis taurina (Rchb. f.) Kuntze, Revis. Gen. Pl.: 573. 1891.

Microstylis taurina Rchb. f., Linnaea 41: 97. 1877.

Terrestrial herb with short erect stems 3-6 (-15 cm) long. Leaves 5-10, ovate, acute, 6-9 × 1.8-3.5 cm; petiole slender, up to $5 \mathrm{~cm}$ long, sheathing at the base. Inflorescence subdensely many-flowered; peduncle 11$15 \mathrm{~cm}$ long; bracts reflexed, linear, acuminate, 4-6 mm long. Flowers small, purple or rarely dull yellowish; pedicel and ovary 3-4 mm long. Dorsal sepal ovate, obtuse, ca. $3 \times 2 \mathrm{~mm}$. Lateral sepals oblong, obtuse, ca. $3 \times 1.5 \mathrm{~mm}$. Petals linear-oblong, obtuse, ca. $3 \times 1 \mathrm{~mm}$. Lip 3-lobed, ca. $4 \times 3.5-4 \mathrm{~mm}$; side lobes hatchetshaped, acute in front; midlobe oblong-elliptic or tapering, emarginate. Column short. Fig. 43.

Distribution. Tonga (Tafahi). Also in Vanuatu, New Caledonia, Samoa, and Fiji.

НАвітAт. Rare, reported from a gully in montane forest; $500 \mathrm{~m}$.

Collections. Tafahi: Buelow 1256.

3. Crepidium latisegmentum (C. Schweinf.) M.A. Clem. \& D.L. Jones, Lasianthera 1 (1): 37. 1996. Type: Fiji, A.C. Smith 967 (holotype AMES!).

Malaxis latisegmenta C. Schweinf., Bernice P. Bishop Mus. Bull. 141: 22, fig. 7c. 1936. Type:

Based on same type as Crepidium latisegmentum.

Oberonia latisegmenta (C. Schweinf.) Parham, Trans. Proc. Fiji Soc. 2: 27. 1953. 
Terrestrial herb $12-30 \mathrm{~cm}$ in height with a creeping rhizome and erect stem $4.5-14 \mathrm{~cm}$ long. Leaves 3-7, ovate to ovate-elliptic, acute, $6-10.5 \times 2.5-5.2 \mathrm{~cm}$; petioles $2.5-7 \mathrm{~cm}$ long. Inflorescence subdensely manyflowered, 8.5-30 cm long; peduncle and rachis weakly costate; bracts lanceolate, acuminate, 5-11 mm long. Flowers greenish yellow to yellow. Dorsal sepal broadly elliptic to elliptic-ovate, 5-6 $\times 3-5 \mathrm{~mm}$. Lateral sepals obliquely suborbicular-obovate, ca. $5 \times 3.1-3.8 \mathrm{~mm}$. Petals spathulate to elliptic- obovate, $4-5 \times 1.8-$ $2.5 \mathrm{~mm}$. Lip cordate, $2.5-3.5 \times 2.3-3 \mathrm{~mm}$, prominently auriculate at base. Column $0.7-0.8 \mathrm{~mm}$ long. Fig. 44 .

Distribution. Tonga (Kao, Tofua, and possibly 'Eua). Also in Fiji, Vanuatu, and the Solomon Islands. HaвiтAт. Uncommon in open foothill forest; 260-450 m.

Collections. 'Eua: ?Wood 6836; Whistler 12166. Kao: Yuncker 15887. Tofua: Buelow 2719.

4. Crepidium brevidentatum (C. Schweinf.) M.A. Clem. \& D.L. Jones, Lasianthera 1, 1: 35. 1996. Type: Fiji, A.C. Smith 1620 (holotype AMES!).

Malaxis brevidentata C. Schweinf., Bernice P. Bishop Mus. Bull. 141: 20, fig. 7a. 1936.

Oberonia brevidentata (C. Schweinf.) Parham, Trans. Proc. Fiji Soc. 2: 27. 1953.

Terrestrial herb $20-65 \mathrm{~cm}$ in height with a creeping rhizome and erect stem $4.5-10.4 \mathrm{~cm}$ long. Leaves 5-7, ovate to ovate-elliptic, acute, $6-13 \times 2.1-4.8 \mathrm{~cm}$; petioles $4-6.5 \mathrm{~cm}$ long. Inflorescence subdensely manyflowered, up to $25 \mathrm{~cm}$ long; peduncle and rachis weakly costate; bracts lanceolate, acuminate, 7-8 mm long. Flowers greenish white to white. Dorsal sepal elliptic-ovate, 3-3.5 $\times 2 \mathrm{~mm}$. Lateral sepals obliquely ellipticlanceolate, 3-3.5 × 2-2.2 mm. Petals oblanceolate to elliptic-lanceolate, 3-3.5 × 1.1-1.3 mm. Lip suborbicular in outline, $3-3.5 \times$ ca. $3 \mathrm{~mm}$, with subdeltoid auricles at base; side lobes weakly denticulate in front; midlobe obtuse or weakly denticulate at apex. Column $0.4-0.8 \mathrm{~mm}$ long. Fig. 45.

Distribution. Tonga ('Eua, Kao, Tofua, and Late). Also in Fiji, Vanuatu, and the Solomon Islands. НавітAт. Occasional in fernlands; 350-1000 m.

Collections. 'Eua: Buelow 166; Sykes 351a; Whistler 5969; Wood 6836; Yuncker 15403. Kao: Buelow 650, 676, 2820; Whistler 10701; Yuncker 15887, 15910. Tofua: Buelow 440, 475, 2593; Hotta 4356; Whistler 10659. Late: Hotta 4807.

5. Crepidium reineckeanum (Kraenzl.) M.A. Clem. \& D.L. Jones, Lasianthera 1(1): 3. 1996. Types: Samoa, Reinecke 311, 620 (syntype $\mathrm{B} \dagger$ ).

Malaxis reineckeana (Kraenzl.) Kores, Allertonia 5 (1): 51.1989.

Malaxis whitmeei (Rolfe) Kores, Allertonia 5 (1): 52.1989.

Microstylis reineckeana Kraenzl., Engler, Bot. Jahrb. Syst. 25: 600. 1898.

Microstylis whitmeei Rolfe, Bull. Misc. Inform. Kew 1922: 23. 1922. Type: Samoa, Whitmee s.n. (holotype K!).

Terrestrial herb with an elongate, erect stem up to $20 \mathrm{~cm}$ in height, leafy along its length, growing from an elongate fleshy stem. Leaves up to 12 , distichous and twisted to lie in one plane, ovate, acute, $7-11 \times 3-5$ $\mathrm{cm}$; petiole sheathing at base, up to $4 \mathrm{~cm}$ long. Inflorescence densely many-flowered, up to $30 \mathrm{~cm}$ long; bracts reflexed, linear, acuminate, 5-6 mm long. Flowers pale yellow, sometimes cleistogamous; pedicel and ovary ca. $5 \mathrm{~mm}$ long. Dorsal sepal oblong, obtuse, $3.5-4 \times 1.5-1.8 \mathrm{~mm}$. Lateral sepals similar to dorsal sepal. Petals oblong, obtuse, 2.5-3 × ca. $1 \mathrm{~mm}$. Lip transversely reniform-suborbicular, obscurely 3-lobed, 4-4.5 × 5-6 mm; midlobe small, emarginate; side lobes rounded, shortly 3-toothed in front. Column short. Fig. 46.

Distribution. Rarotonga. Also in Samoa and the Solomon Islands.

НАвIтAT. Rare in foothill to montane forest; 400-500 m.

Collections. Rarotonga: Luttrell 356. 


\section{OBERONIA}

Lindl., Gen. Sp. Orchid. Pl.: 15. 1830.

Small to large epiphytic herbs with short to long leafy stems, lacking pseudobulbs. Leaves iridiform, equitant, short to long, often fleshy, articulated or not at base, distichous, often imbricate at base. Inflorescence terminal, laxly to densely many-flowered, pubescent or glabrous. Flowers often in whorls, small, non-resupinate, flat. Sepals and petals free, spreading. Lip larger, sessile, entire or lobed, usually spreading, occasionally somewhat concave at base. Column short; anther terminal; pollinia four, waxy, cohering in two pairs.

A genus of some 150-200 species centered on tropical South and S.E. Asia and the Malay Archipelago, but extending to tropical Africa, Madagascar, the Mascarene Islands, the Philippines, New Guinea, Australia, and the S.W. Pacific islands eastward to Tahiti. A single species occurs in Tonga, Niue, and the Cook Islands.

Oberonia equitans (Forst. f.) Mutel, Premier Mém. Orchid. Paris: 8. 1838. Type: Tahiti, G. Forster 170 (holotype BM!, isotype P!).

Cymbidium equitans (Forst. f.) Sw., Nova Acta Regiae Soc. Sci. Upsal. 6: 72. 1799.

Epidendrum equitans Forst. f., Fl. Ins. Austr.: 60. 1786.

Malaxis equitans sensu Hallé, Fl. Nouv-Caléd. 8: 270, pro syn. 1977, non Blume.

Malaxis glandulosa (Lindl.) Rchb. f., Ann. Bot. Syst. 6: 215. 1861.

Oberonia brevifolia sensu Seem., Bonplandia 10: 153. 1861, non Lindl.

Oberonia aff. diura sensu Christoph., Bernice P. Bishop Mus. Bull. 128: 63. 1935, non Schltr. 1905.

Oberonia flexuosa Schltr., Engler, Bot. Jahrb. Syst. 39: 61. 1906. Type: New Caledonia, Schlechter 15496 (holotype B†ं).

Oberonia glandulosa Lindl., Fol. Orchid.: 6. 1859. Type: Pacific islands, Matthews 158 (holotype $\mathrm{K}$, not traced).

Oberonia palmicola sensu Parham, Trans. Proc. Fiji Soc. 2: 27. 1953, non F. Muell.

Small epiphytic herb $14-21 \mathrm{~cm}$ in height, with elongate, flexuose stems up to $14 \mathrm{~cm}$ long and covered by imbricate leaf bases. Leaves in two rows, imbricate, iris-like, narrowly lanceolate-falcate, acute, 2-6 $\times 0.4-0.8 \mathrm{~cm}$. Inflorescence cylindrical, up to $10 \mathrm{~cm}$ long, densely many-flowered, minutely pubescent; bracts subdeltoid, 1.5-2 mm long, erosulate. Flowers verticillate, greenish cream to creamcolored; ovary ca. $1.5 \mathrm{~mm}$ long, papillate. Dorsal sepal oblong, obtuse, ca. $1 \mathrm{~mm}$ long, sparsely papillate on outer surface. Lateral sepals similar. Petals oblong-ovate, acute to subacute, ca. $0.8 \mathrm{~mm}$ long. Lip subentire, subquadrate, obscurely bilobulate at apex, biauriculate at base, ca. $1 \mathrm{~mm}$ long. Column very short. Fig. 47.

Distribution. Tonga ('Eua, Kao, Tofua, and Tongatapu), the Cook Islands (Mangaia and Rarotonga), and Niue. Also in the Solomon Islands, Vanuatu, New Caledonia, Fiji, Samoa, Tahiti, and the Tuamotus.

HАвітAт. Occasional in lowland to montane forest; near sea level to $400 \mathrm{~m}$.

Collections. 'Eua: Hotta 5364; Hurlimann 263; Parks 16237A; Sykes 489; Whistler 7125, 7482; Yuncker 15402. Tongatapu: Hotta 4026. Kao: Buelow 654, 655, 660; Whistler 10727. Tofua: Buelow 547, 2671. Rarotonga: Cheeseman 675, s.n.; Given 1439; Parks 22145, 22589; Philipson 10132, 10206, 10381; Sykes 1546, 1947, 2201; Whistler 4063, 5038; Wilder 8, 972. Niue: Sykes CHR 150564, 150565; Whistler 10739; Yuncker 9598. Mangaia: Sykes 564, 655; Whistler 5825. 


\section{Appendicula}

Blume, Bijdr. Fl. Ned. Ind.: 297. 1825.

Small to large epiphytic or lithophytic herbs with a short rhizome and leafy, clustered, unbranched (or rarely laxly branched near base) stems covered by persistent sheathing leaf bases. Leaves distichous, relatively thin-textured, ligulate to narrowly elliptic, often twisted at base to lie in one plane. Inflorescence terminal or axillary, simple to branched, short to long, few- to many-flowered. Flowers small, resupinate, white, greenish or yellow. Dorsal sepal free, erect. Lateral sepals united at base to column-foot to form a more or less saccate mentum. Petals free, smaller than sepals. Lip adnate to apex of column-foot, immobile, more or less entire or weakly 3-lobed, with a more or less horseshoe-shaped transverse callus. Column short with a prominent foot; pollinia six, waxy, clavate to pear-shaped.

A genus of about 100 species widespread in tropical Asia and S.E. Asia, the Malay Archipelago, New Guinea, the Philippines, and the S.W. Pacific islands eastward to New Caledonia and Samoa. A single species has been reported in Tonga.

Appendicula reflexa Blume, Bijdr. Fl. Ned. Ind. 301. 1825. Type: Java, Blume s.n. (holotype L!). For full synonymy, see Lewis \& Cribb (1989).

Epiphytic herb with stems up to $60 \mathrm{~cm}$ long, concealed by persistent distichous sheaths. Leaves many, distichous, twisted at base to lie in one plane, oblong-lanceolate, $3.5-5 \times 0.8-1.5 \mathrm{~cm}$, bluntly bilobed at apex. Inflorescence lateral, opposite and shorter than the leaves, ca. $1 \mathrm{~cm}$ long, 2-4-flowered. Flowers small, white, turning yellowish with age. Dorsal sepal narrowly elliptic, obtuse, ca. $2.5 \times 1.3 \mathrm{~mm}$. Lateral sepals broadly triangular, ca. $3 \times 2.5 \mathrm{~mm}$; mentum blunt, ca. $3 \mathrm{~mm}$ long. Petals oblong-elliptic, obtuse, ca. $2 \times 1 \mathrm{~mm}$. Lip simple, ovate, obtuse, ca. $3 \times 2 \mathrm{~mm}$, slightly saccate at base; callus elliptic. Column and foot ca. $2.5 \mathrm{~mm}$ long. Fig. 48 .

Distribution. Tonga (Kao and Tofua). Also in New Guinea, New Caledonia, Fiji, Vanuatu, and the Solomon Islands.

НавітAт. Occasional in foothill to montane forest; 300-500 m.

Collections. Kao: Buelow 615; Whistler 10700; Yuncker 15897. Tofua: Buelow 438, 2549; Hotta 4411; Whistler 10607.

\section{Phreatia}

Lindl., Gen. Spec. Orchid. Pl.: 63. 1830.

Dwarf to medium-sized epiphytic herbs, with leafy, short to long or pseudobulbous stems. Leaves solitary to many, somewhat thin-textured to fleshy or leathery, articulate. Inflorescence basal or axillary, unbranched, racemose, laxly to densely many-flowered. Flowers resupinate, small or tiny, white, rarely pale green or pale yellow. Dorsal sepal free. Lateral sepals oblique, attached at base to column-foot to form a distinct mentum. Petals narrower than dorsal sepal, free. Lip adnate to column-foot, immobile, concave or saccate at base, usually with two small pit-like nectaries, the disc naked or papillate. Column short, with a foot; pollinia eight, borne on a small linear stipe attached to a small viscidium.

A genus of 100 or more species widespread in tropical Asia from India and Sri Lanka eastward to New Guinea, N.E. Australia, and the S.W. Pacific islands eastward to Tahiti. Two species occur in Tonga and Niue. 


\section{Key to Species}

1. Leaves $11-30 \times 1.2-2 \mathrm{~cm}$; lip lacking a spur 1. P. micrantha

1. Leaves $4-10.5 \times 0.2-0.5 \mathrm{~cm}$; lip with an obscurely saccate spur

2. P. matthewsii

1. Phreatia micrantha (A. Rich.) Lindl., J. Proc. Linn. Soc., Bot. 3: 212. 1859. Type: Santa Cruz Islands, Vanikoro, Lesson s.n. (holotype P!).

Eria sphaerocarpa Rchb. f., Seem. Fl. Vit. 301. 1868. Type: Fiji, Graeffe s.n. (holotype W!).

Oberonia micrantha A. Rich., Voy. Astrolabe: 7, tab. 3. 1833.

Phreatia collina Schltr., Repert. Spec. Nov. Regni Veg. Beih. 1: 919. 1913. Type: New Guinea, Schlechter 16438 (holotype B†), non J.J.Sm. (1911).

Phreatia graeffei Kraenzl., Engler Pflanzenr. Orch. Thelas. 26. 1911. Based on same type as Eria sphaerocarpa Rchb. f.

Phreatia macrophylla Schltr., Engler Bot. Jahrb. Syst. 39: 78. 1906. Type: New Caledonia, Schlechter 15465 (holotype B†, isotype BM!, K!, P!, W!, Z).

Phreatia robusta R.S. Rogers, Trans. \& Proc. Roy. Soc. South Australia 54: 3. 1930. Type: Australia, A. Beck s.n. (holotype AD).

Phreatia samoensis (Kraenzl.) Schltr., Repert. Spec. Nov. Regni Veg. 3: 320. 1907.

Phreatia sarcothece Schltr., Repert. Spec. Nov. Regni Veg. 9: 438. 1911. Type: Vanuatu, Morrison s.n. (holotype $\mathrm{B} \dagger$ ).

Rhynchophreatia micrantha (A. Rich.) N. Hallé, Fl. Nouv.-Caléd. 8: 341. 1977.

Thelasis samoensis Kraenzl., Engler, Bot. Jahrb. Syst. 25: 607. 1898. Type: Le Pua [Lepu'e?], Reinecke 606 (syntype $\mathrm{B} \uparrow$, isosyntype AMES!).

Medium-sized epiphytic herb with a very short stem. Leaves in a fan-shaped arrangement, 5-10, ligulate, unequally obtusely bilobed, $11-30 \times 1.2-2.2 \mathrm{~cm}$, articulated to broad, conduplicate, imbricate leaf bases 3-5 mm long. Inflorescence axillary, usually slightly longer than the leaves, cylindrical, subdensely manyflowered; peduncle twice as long as the rachis; bracts ovate, subulate, $2.5-4 \mathrm{~mm}$ long. Flowers tiny, white; pedicel and ovary 1.5-2 mm long. Dorsal sepal broadly ovate, obtuse, $1.2-1.5 \times 1-1.5 \mathrm{~mm}$. Lateral sepals oblique, broadly ovate, obtuse, $1-1.5 \times 0.9-1.2 \mathrm{~mm}$; mentum short, obtuse. Petals broadly ovate, subacute, $0.8-1.1 \times 0.7-1 \mathrm{~mm}$. Lip inflexed, subrhombic to broadly trullate, obtuse, 1-1.7 × 1.3-1.6 mm, lacking a spur. Column ca. $0.4 \mathrm{~mm}$ long; foot ca. $0.7 \mathrm{~mm}$ long. Fig. 49.

Distribution. Tonga (Kao, Tofua, and Tafahi) and Niue. Also found from Micronesia, N. Australia, New Guinea, the Solomon Islands, Vanuatu, and New Caledonia eastwards to Samoa.

НАвітAт. Occasional in forests on volcanic islands; near sea level to $300 \mathrm{~m}$.

Collections. Kao: Buelow 3116, 3157, 3199; Yuncker 15902. Tofua: Hotta 4361, 4365; ScarthJohnson 150. Niue: Sykes CHR 150573, 150574, 150575; Whistler 10767, 10842; Yuncker 9807, 10105.

2. Phreatia matthewsii Rchb. f., Otia Bot. Hamburg.: 55. 1878. Type: Society Islands, Matthews S.n. (holotype $\mathrm{W} !)$.

Eria myosurus (Forst. f.) Rchb. f., Bonplandia 5: 54. 1857.

Eria stachyurus Rchb. f., Seem., Fl. Vit.: 301. 1868.

Phreatia multiflora sensu Kraenzl., Bot. Jahrb. Syst. 25: 607. 1898, non Lindl.

Phreatia myosurus (Forst. f.) Ames, Orchidaceae 2: 203. 1908, non (Rchb.f.) Lindl. (1859).

Type: Society Islands, Banks \& Solander s.n. (holotype BM!). 
Phreatia neocaledonica Schltr., Bot. Jahrb. Syst. 39: 78. 1906. Types: New Caledonia, Schlechter 14755, 15228 (syntype B†; isosyntypes BM, BO, K, P, Z).

Phreatia reineckei Schltr., Fedde, Repert. Spec. Nov. Regni Veg. 9: 109. 1911. Type: Samoa, Vaupel 658 (holotype B†; isotype K!).

Phreatia upoluensis Schltr., Repert. Spec. Nov. Regni Veg. 3: 319. 1907. Type: Samoa, Betche 36 (holotype $\mathrm{B} \uparrow$, isotype MEL).

Phreatia yunckeri L.O. Williams, Bernice P. Bishop Mus. Bull. 178: 42. 1943). Types: Niue, Yuncker 9597, 9928 (syntypes AMES!).

Small epiphytic herb with a short stem 1-4 cm long. Leaves 6-10, in a fan-shaped arrangement, linearligulate, briefly obliquely unequally bilobed at apex, $4-10.5 \mathrm{~cm} \times 2-5 \mathrm{~mm}$, with articulated to sheathing, imbricate leaf bases. Inflorescence axillary, more or less as long as the leaves, $3-11 \mathrm{~cm}$ long, laxly manyflowered; peduncle about half as long as the rachis; bracts lanceolate, acuminate, $1.5-2 \mathrm{~mm}$ long. Flowers tiny, white; pedicel and ovary ca. $1 \mathrm{~mm}$ long. Dorsal sepal ovate, subacute, $0.8-1.2 \times 0.6-0.8 \mathrm{~mm}$. Lateral sepals obliquely ovate, acute, $1-1.5 \times 0.9-1.2 \mathrm{~mm}$; mentum subconical. Petals elliptic-ovate, acute, $0.8-1.2 \times 0.6-0.8$ $\mathrm{mm}$. Lip clawed, with a transversely ovate, obtuse lamina $0.9-1.3 \times 0.7-0.9 \mathrm{~mm}$, obscurely saccate at base. Column short; foot ca. $0.3 \mathrm{~mm}$ long. Fig. 50.

Distribution. Tonga (Tafahi) and Niue. Also in New Ireland, Bougainville, the Solomon Islands, Vanuatu, the Horne Islands, Fiji, Samoa, and the Society Islands.

НАвітAт. Uncommon in lowland to montane forest; near sea level to $550 \mathrm{~m}$.

Collections. Tafahi: Hurlimann 437. Buelow 1190, 1191; Whistler 6244. Niue: Sykes 110, CHR 150589, 150591, 150592; Whistler 10766, 10841; Yuncker 9597, 9928.

\section{DendRobium}

Sw., Nova Acta Regiae Soc. Sci. Upsal. ser. 2, 6: 82. 1799.

Small to large epiphytic or lithophytic herbs (or rarely terrestrial) with elongate, 1- to several-noded, slender and leafy or swollen stems, pseudobulbous, leafy towards apex. Leaves coriaceous to fleshy, flat, terete or bilaterally flattened, articulated at base; leaf base present or not. Inflorescence lateral or subterminal, axillary, one- to many-flowered, fasciculate, racemose, or paniculate. Flowers often showy and relatively large. Dorsal sepal free. Lateral sepals adnate to column-foot, forming a distinct mentum. Petals free, usually narrower than the sepals. Lip attached to apex of column-foot, mobile or articulated, entire to 3-lobed, lacking a spur, usually with a callus of ridges or appendages. Column short, with a short to long foot; pollinia four, waxy, lacking an appendage.

A large genus of perhaps 1000 or more species widespread in tropical and subtropical Asia, Malesia, the Philippines, Micronesia, N. and E. Australia, and the S.W. Pacific eastward to Tahiti and south to New Caledonia and New Zealand. Four species are reported from Tonga (one of them also in the Cook Islands) and one on Niue.

\section{Key to Species}

1. Flowers borne in pairs in sessile inflorescences along the stems and opposite the leaves

2. Leaves $10-25 \mathrm{~mm}$ broad

2. Leaves $4-7 \mathrm{~mm}$ broad

2. D. biflorum

1. Flowers not borne in sessile inflorescences opposite the leaves, usually three- or more-flowered

2. Stems clavate and strongly bilaterally flattened 3. D. platygastrium

2. Stems terete, not clavate or bilaterally flattened 
3. Mentum spur-like, longer than the dorsal sepal; flowers small, pale orange in dense clusters much shorter than the leaves

3. Mentum chin-like, shorter than the dorsal sepal; flowers large, greenish yellow or yellow, in open, well-spaced racemes much longer than the leaves

1. Dendrobium dactylodes Rchb.f., J. Bot. 15: 132 (1877). Type: Samoa, Whitmee 46 (holotype W!, isotype $\mathrm{K}$ !, photo of holotype AMES!).

Dendrobium cheesmanae Guillaumin, Bull. Soc. Bot. France 103: 280. 1956. Type: Vanautu, Cheesman A22 (holotype BM!).

Dendrobium everardii Rolfe, Bull. Misc. Inform. Kew 1921: 55. 1921. Type: Viti Levu, Im Thurn 326 (holotype K!).

Dendrobium involutum sensu Kraenzl., Bot. Jarhb. Syst. 25: 603. 1898, non Lindl.

Dendrobium vaupelianum Kraenzl., Notizbl. Königl. Bot. Gart. Berlin 5: 109. 1909. Type: Samoa, Vaupel 286 (holotype B $\dagger$, isotypes AMES!, K!).

Dendrobium whitmeei Kraenzl., Engler Pflanzenr. Orch. Mon. Dendr. 1:; 45: 189. 1910. Types: Samoa, Whitmee s.n. (syntype B!), Betche 227 (syntype B!).

Epiphytic herb with clustered slender stems $25-140 \mathrm{~cm}$ long, leafy, many-noded. Leaves distichous, lanceolate, obliquely obtuse or subacute at apex, $3.5-8 \times 1-2.5 \mathrm{~cm}$, articulated to sheathing leaf bases, $5-10$ $\mathrm{mm}$ long. Inflorescence lateral, 2-flowered, borne at nodes opposite leaves, 3-6 mm long; bracts small, scalelike. Flowers white to pale creamy white or tinged with pink, ephemeral; pedicel and ovary $7-13 \mathrm{~mm}$ long. Dorsal sepal linear-lanceolate, acute, 15-24 × 3-3.5 mm. Lateral sepals falcate, lanceolate, attenuate, acute, 13-28 $\times$ 6-10 mm; mentum inflexed, conical, 5-7 mm long. Petals linear-lanceolate, acute, 13-24 × 1-2 mm. Lip 3-lobed, recurved, 7-14 $\times 5-8 \mathrm{~mm}$; side lobes erect, obliquely ovate, subacute to obtuse; midlobe ovate, attenuate, acuminate, sparsely papillate at apex of callus, the margins irregularly crenate-dentate below; callus with a prominently raised keel, verruculose in basal part, crenate in apical part. Column 3-3.5 mm long; foot 4.5-6 mm long. Section Grastridium. Fig. 51.

Distribution. Tonga (Tafahi) and the Cook Islands (Rarotonga). Also found in Vanuatu, Fiji, Samoa, and the Cook Islands.

HaBitat. Common in coastal to cloud forest; near sea level to perhaps $600 \mathrm{~m}$ on these islands. Collections. Tafahi: Buelow 1186, 1274; Hurlimann 463; Whistler 6243. Rarotonga: Cheeseman A22; Given 1438; Luttrell 352; Parks 22132; Philipson 10149; Sykes 1547; Whistler 4058, 5783; Wilder 969.

Note. Very close to Dendrobium involutum Lindl. from Tahiti and adjacent islands. Their relationship needs further exploration.

2. Dendrobium biflorum (Forst. f.) Sw., Nova Acta Regiae Soc. Sci. Upsal. Ser. 2, 6: 84. 1799. Type: Tahiti, J. \& G. Forster s.n. (holotype BM!, isotype K!).

Epidendrum biflorum Forst. f., Fl. Ins. Austr.: 60 (1786).

Erect or ascending epiphytic herb with slender, reed-like, many-noded stems $35-160 \mathrm{~cm}$ long, 2-4 $\mathrm{mm}$ in diameter, leafy in upper part. Leaves distichous, linear-lanceolate, obliquely acute, 7-16 $\times 4-7 \mathrm{~mm}$, articulated at base to tubular sheaths, $1-1.4 \mathrm{~cm}$ long. Inflorescence 2-flowered, borne at nodes opposite leaves; peduncle 3-7 mm long; bracts narrowly triangular, $1-1.5 \mathrm{~mm}$ long. Flowers ephemeral, white to pale yellow; pedicel and ovary 7-12 mm long. Dorsal sepal linear-lanceolate, filiform at apex, 28-32 $\times 1.5-2 \mathrm{~mm}$. Lateral sepals obliquely linear-lanceolate, filiform at apex, 30-34 $\times 2-3 \mathrm{~mm}$; mentum narrowly conical, 4-6.5 mm long. Petals linear-attenuate, filiform, 28-32 × 1-1.5 mm. Lip 3-lobed, recurved, 6-8 $\mathrm{mm}$ long, 3.5-4.5 mm wide; 


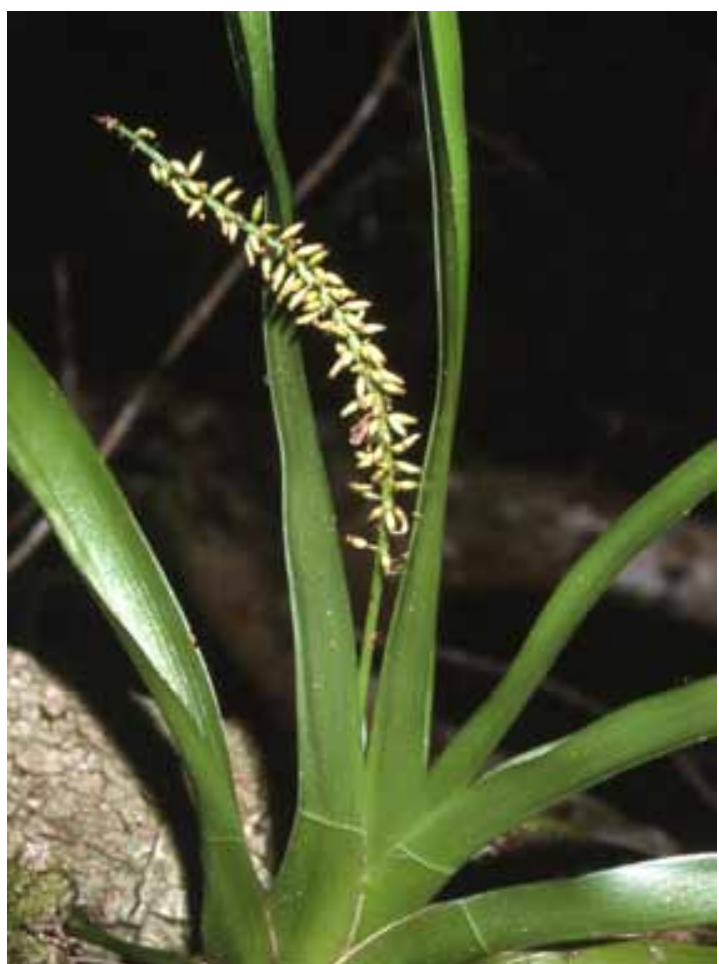

Figure 49. Phreatia micrantha. Niue.

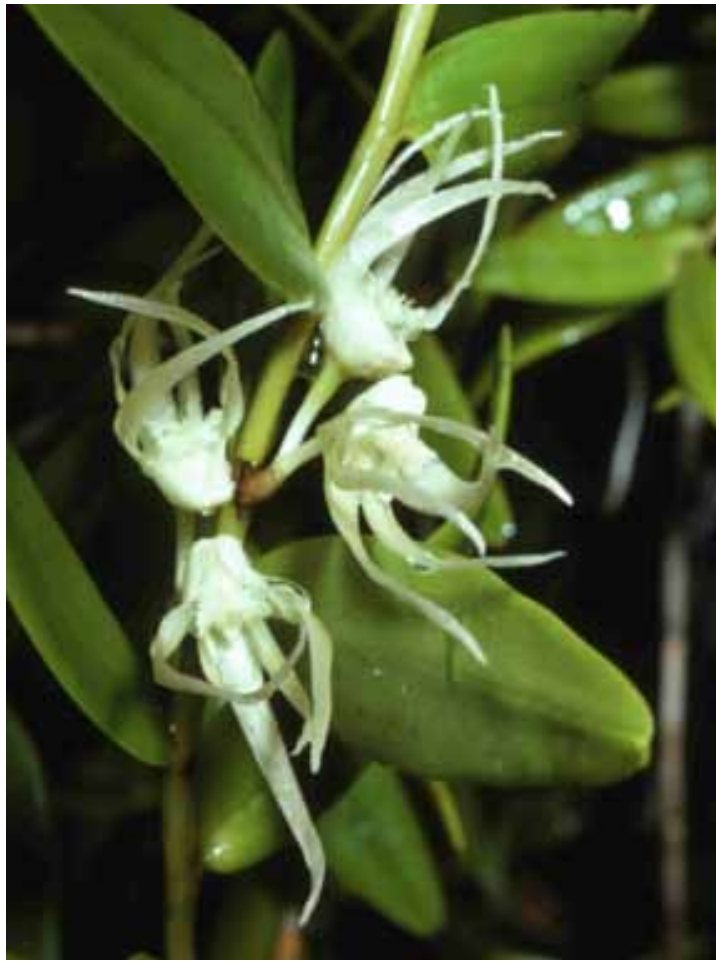

FIgURE 51. Dendrobium dactylodes. Samoa.

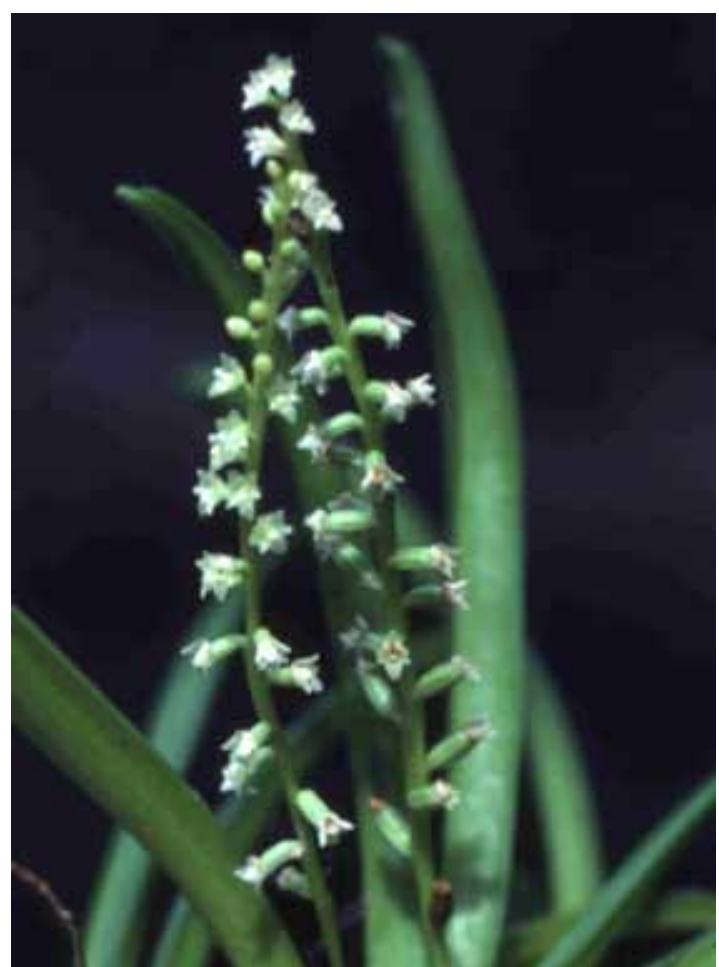

FIgure 50. Phreatia matthewsii. Tahiti.

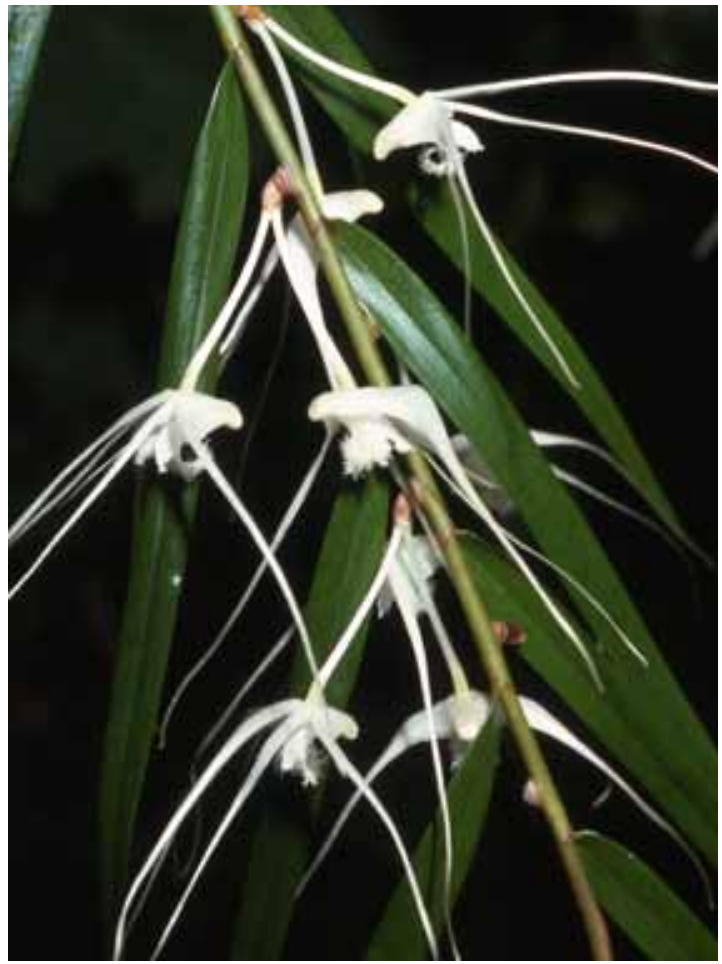

FIgURE 52. Dendrobium biflorum. Samoa.

LANKESTERIANA 11(2), August 2011. (C) Universidad de Costa Rica, 2011. 


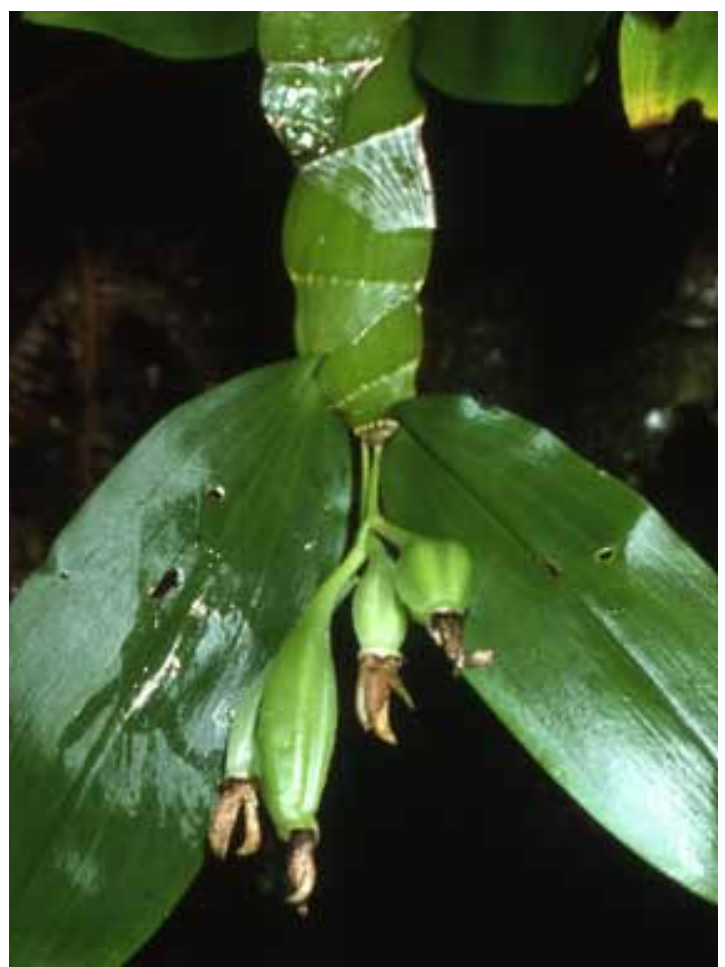

FIGURE 53. Dendrobium platygastrum. Tonga.

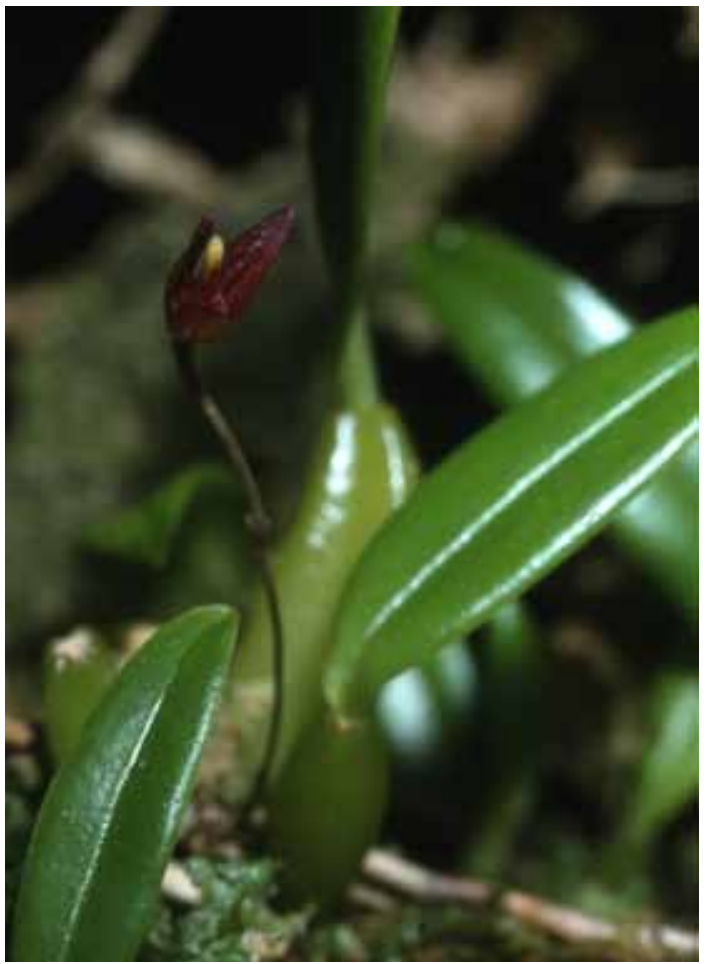

FIGURE 55. Bulbophyllum rosticeps. Tonga.

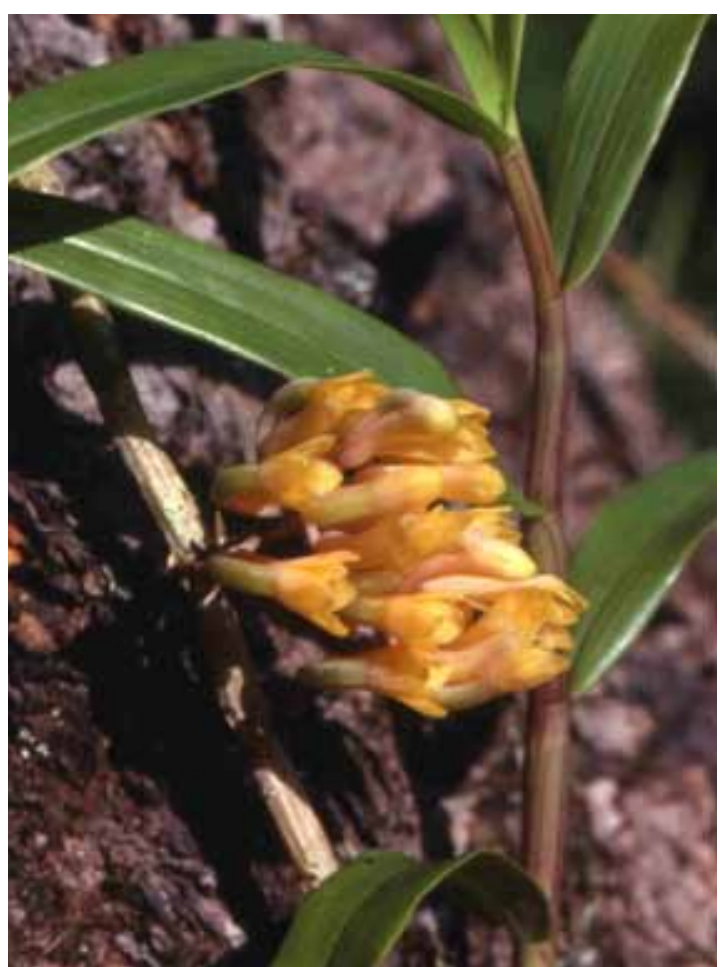

FIGURE 54. Dendrobium calcaratum.

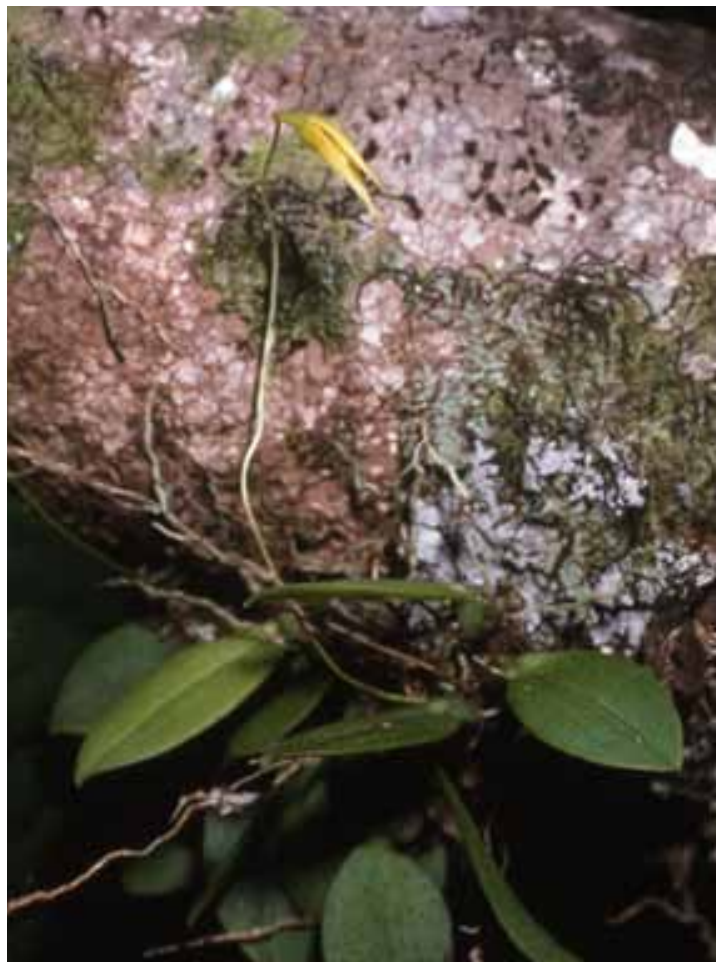

FIGURE 56. Bulbophyllum distichobulbon. Niue. 


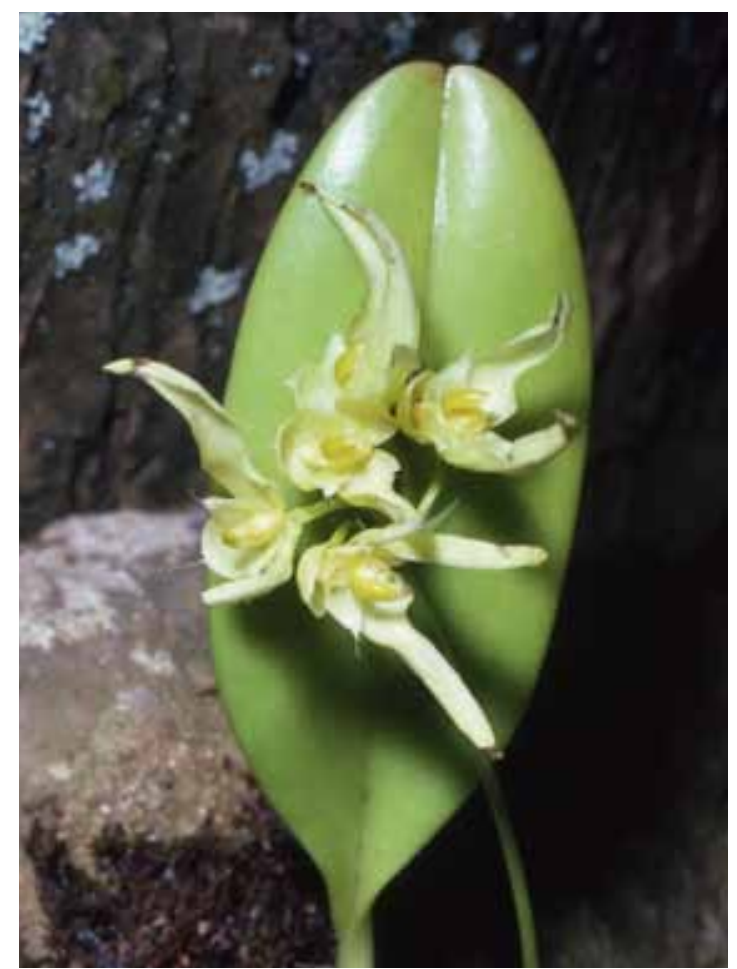

Figure 57. Bulbophyllum longiflorum. Cooks.

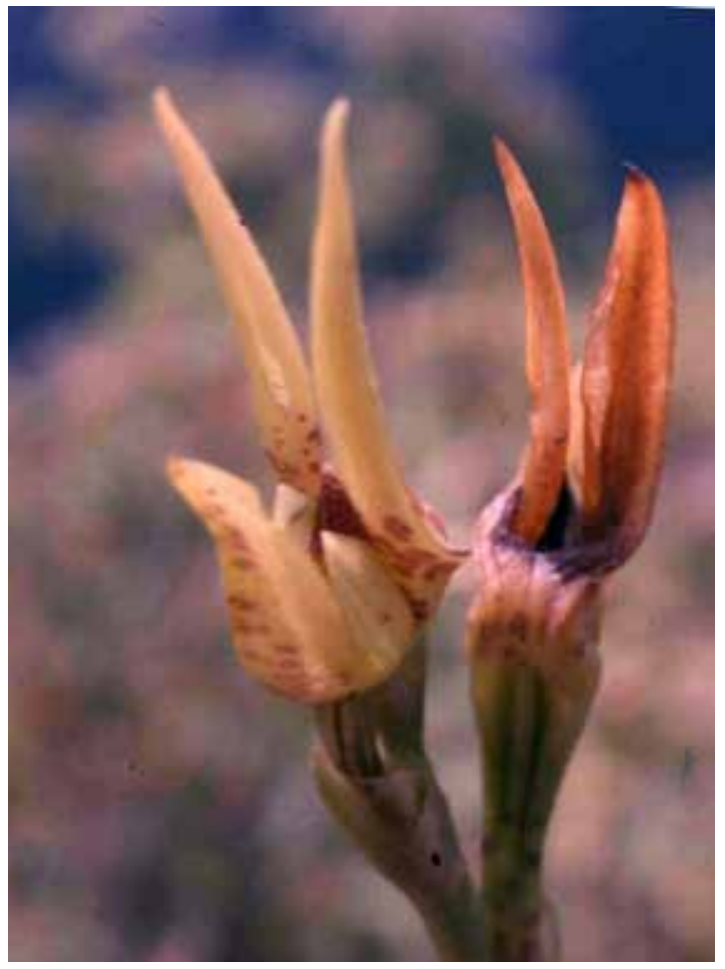

FIGURE 59. Bulbophyllum pachyanthum. Samoa.

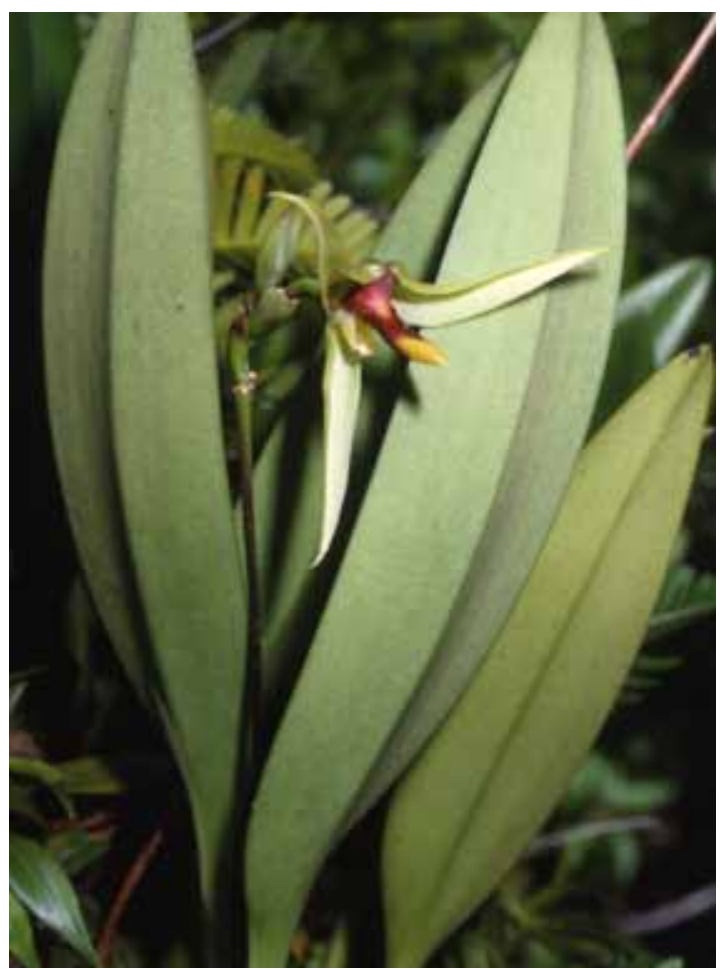

FIGURE 58. Bulbophyllum longiscapum. Samoa.

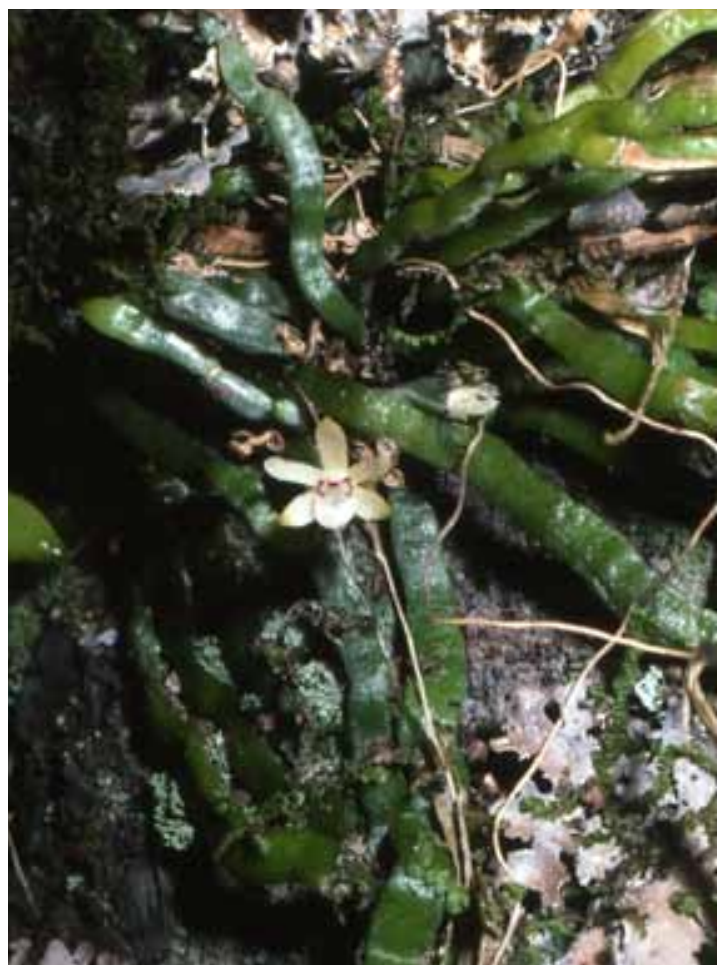

FIGURE 60. Taeniophyllum fasciola. Cooks.

LANKESTERIANA 11(2), August 2011. (C) Universidad de Costa Rica, 2011. 

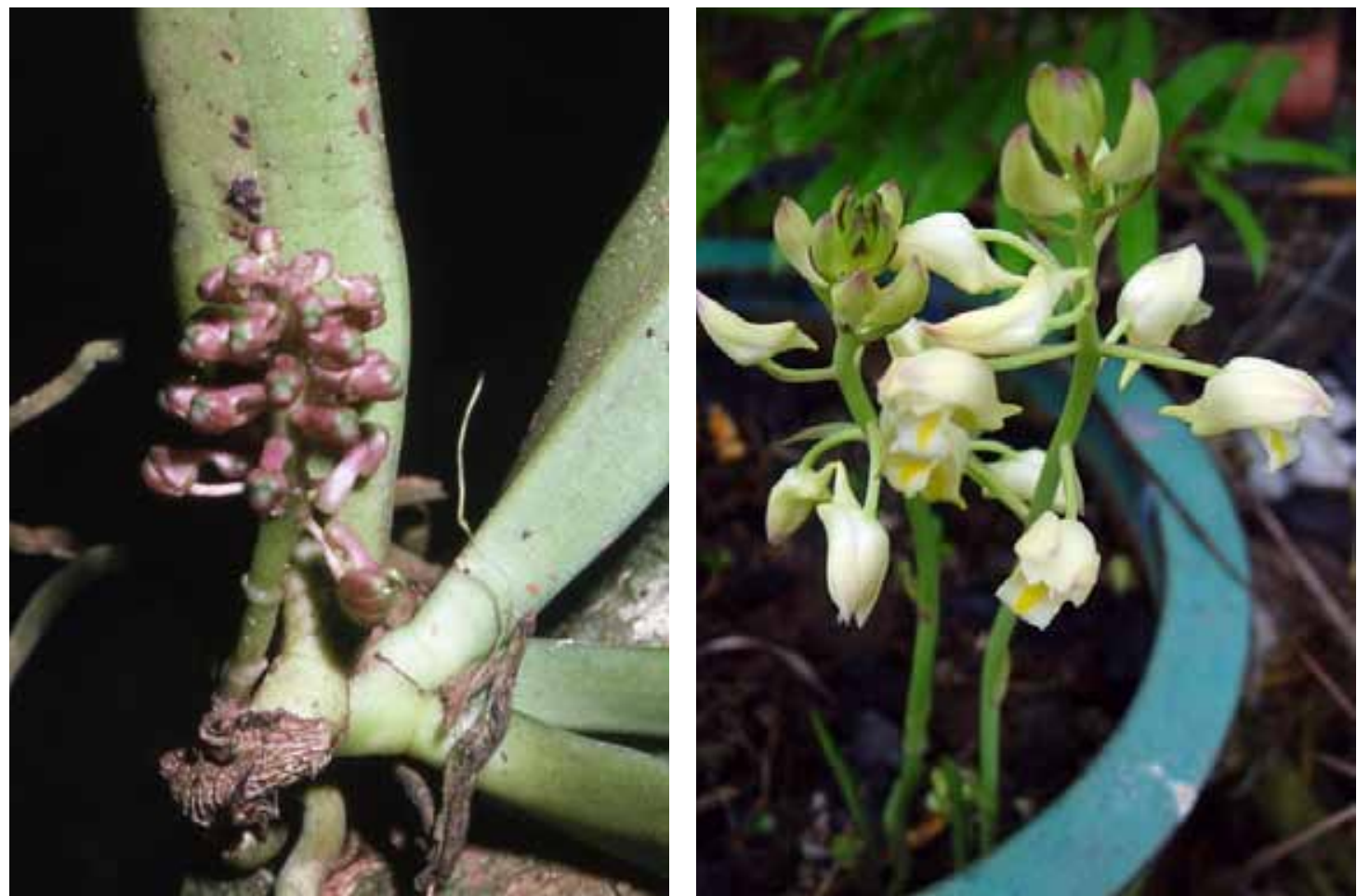

FIGURE 61. Robiquetia tongaensis. Tonga.

FIGURE 62. Eulophia spectabilis.
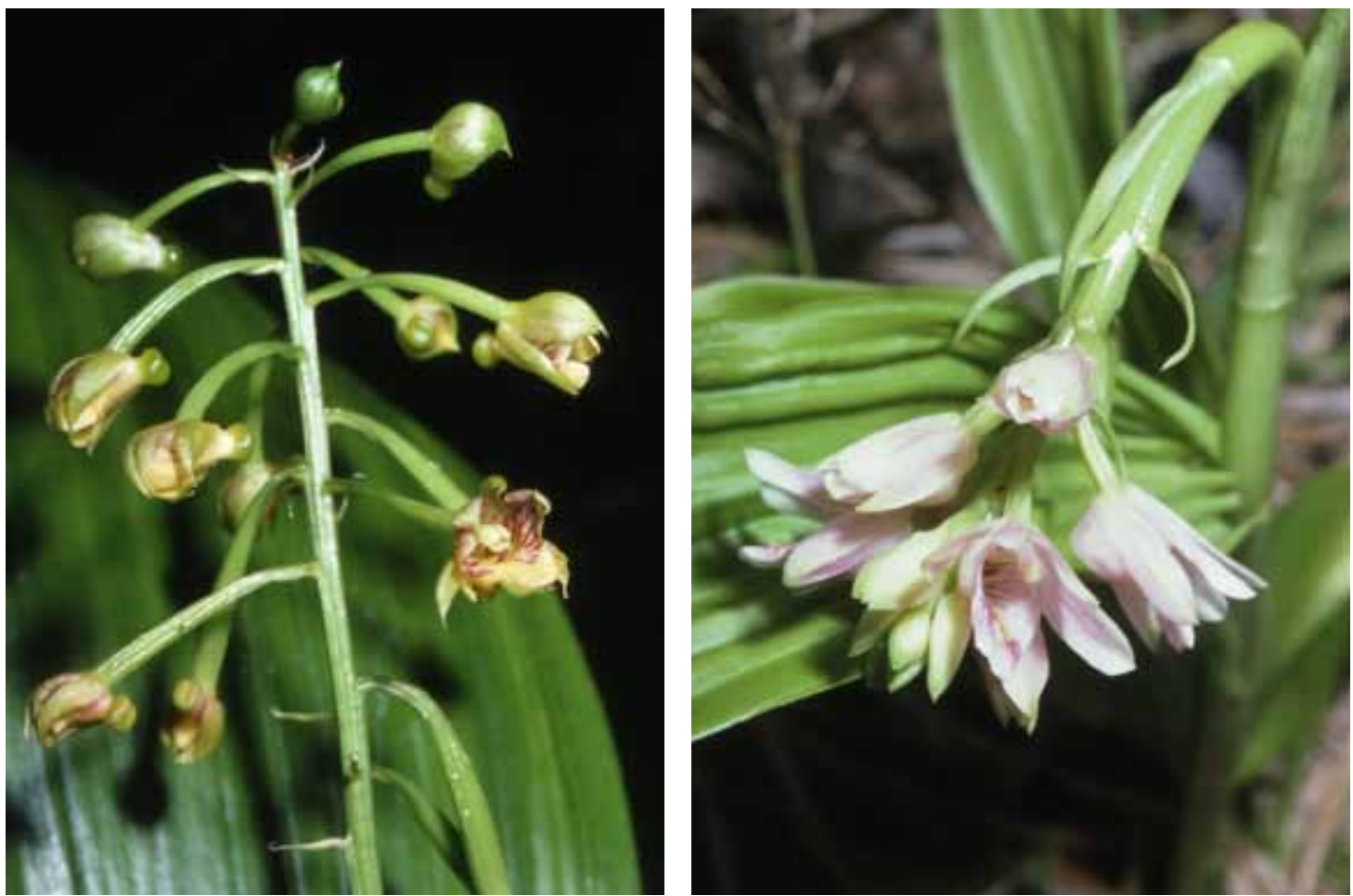

FigURE 63. Eulophia pulchra. Tonga.

FIGURE 64. Geodorum densiflorum. Tonga.

LANKESTERIANA 11(2), August 2011. (c) Universidad de Costa Rica, 2011. 
side lobes obliquely narrowly triangular, acute, erose on margins; midlobe narrowly triangular, acute, 3-4× 2-2.5 mm, irregularly fimbriate on lower margins; callus a longitudinal raised keel from base of lip merging into 3 rows of papillae on basal part of midlobe. Column 1.5-2 mm long; foot 4.5-6 mm long. Section Grastridium. Fig. 52.

Distribution. Niue. Also in Bougainville, the Solomon Islands, the Santa Cruz Islands, Vanuatu, Fiji, Samoa, and the Society Islands.

Habitat. Common in lowland to montane forest; near sea level to perhaps $200 \mathrm{~m}$ on Niue.

Collections. Niue: Sykes CHR 150563; Whistler 10750; Yuncker 9873.

3. Dendrobium platygastrium Rchb.f., Otia Bot. Hamburg. 55. 1878. Type: Fiji, Vanua Levu, USEE s.n. (holotype $\mathrm{W}$ !, isotype AMES!).

Dendrobium goldfinchii sensu M. Hotta, non F. Muell. For full synonymy, see Kores (1991).

Epiphytic herb up to $30 \mathrm{~cm}$ in height with a short rhizome, clavate but bilaterally flattened pseudobulbs 10-25 $\times 1.8-3.5 \mathrm{~cm}$, many-noded stems 3-6-leafed towards apex. Leaves lanceolate to elliptic-oblong, acute, 6-12 × 2-3.5 cm, articulated to persistent sheaths. Inflorescence laxly 2-4-flowered, up to $4 \mathrm{~cm}$ long; bracts ovate, 2-3 mm long. Flowers non-resupinate, white or white tinged with pink. Dorsal sepal ovate to ellipticovate, $12-13.5 \times 6-7 \mathrm{~mm}$. Lateral sepals obliquely ovate, 10-15.5 × 7-9 mm; mentum narrowly conical, 12-15 mm long. Petals obovate-oblong, 10-14 × 6-7 mm. Lip adnate to column-foot, broadly subrhombic, clawed, 16-23 × 7-10 mm; callus of 5 weakly undulate longitudinal ridges. Column ca. $3 \mathrm{~mm}$ long; foot 13-16 mm long. Section Platygastrium. Fig. 53.

Distribution. Tonga (Kao and Tofua). Also in the Philippines, Borneo, the Solomon Islands, Vanuatu, New Caledonia, and Fiji.

НАвітAт. Uncommon in coastal to montane forest; near sea level to $600 \mathrm{~m}$.

Collections. Kao: Buelow 649, 712, 2823, 3158, 3198; Yuncker 15934. Tofua: Hotta 4406; Whistler 10618 .

4. Dendrobium calcaratum A. Rich., Voy. Astrolabe 2: 18. 1834. Type: Santa Cruz Islands, Vanikoro, Lesson s.n. (holotype P!, isotype W!).

Dendrobium separatum Ames, J. Arnold Arb. 13: 133. 1932. Type: Santa Cruz Islands, Kajewski 503 (holotype AMES!).

Dendrobium triviale Kraenzl., Bot. Jahrb. Syst. 25: 604 (1898). Type: Samoa, Reinecke 422 (holotype $\mathrm{B} \dagger$ ).

Pedilonum separatum (Ames) Rauschert, Feddes Repert. 94 (7-8): 463 (1983).

Pedilonum triviale (Kraenzl.) Rauschert, loc.cit. 464.

Pendent epiphytic herb with long, clustered, ribbed leafy stems up to $1.5 \mathrm{~m}$ long, yellow-green turning maroon with age. Leaves deciduous, distichous, coriaceous, ligulate or oblong-lanceolate, acute and unequally bilobed at apex, 9-16 × 1.3-1.7 cm. Inflorescence several, lateral, pendent, from nodes on leafless stems, densely 10-18-flowered; peduncle up to $2 \mathrm{~cm}$ long; bracts 2-4 mm long. Flowers pale apricot to orange, not opening widely; pedicel and ovary ca. $1 \mathrm{~cm}$ long. Dorsal sepal oblong, obtuse, 5-6 $\times$ ca. $3 \mathrm{~mm}$. Lateral sepals obliquely oblong-ovate, obtuse, $14-15 \times 3-4 \mathrm{~mm}$; mentum cylindrical, obtuse, 7-8 mm long. Petals elliptic, obtuse, 5-6 $\times 2-3 \mathrm{~mm}$, with erose margins. Lip obovate, obtuse, $9-10 \times 3-4 \mathrm{~mm}$ with a lunate transverse callus in basal part. Column 2-3 mm long; foot ca. $8 \mathrm{~mm}$ long. Section Pedilonum. Fig. 54.

Distribution. Tonga (Kao, Tofua, Late, Niuafo'ou, and Niuatoputapu). Also in New Britain, the Solomon Islands, the Santa Cruz Islands, Vanuatu, Samoa, Tonga, and the Horne Islands. 
НАвітAт. Often common and abundant from mangrove to montane forest, also on lava fields; near sea level to $700 \mathrm{~m}$.

Collections. Kao: Buelow 668. Tofua: Buelow 448, 2623; Hotta 4362, 4367, 4420. Late: Buelow \& Sykes 110; Hotta 4720, 4792. Niuafo'ou: Whistler (sight record). Niuatoputapu: Whistler 6182.

5. Dendrobium tokai Rchb.f., Hamburger Garten-Blumenzeitung 21: 293. 1865. Type: Fiji, Seemann 584 (lectotype W!; isolectotypes AMES!, BM!, K!, P!).

Epiphytic herb up to $80 \mathrm{~cm}$ or more in height, with clustered, leafy, cane-like stems arising from a short stout rhizome. Leaves many, distichous, coriaceous, elliptic or ovate-elliptic, obtuse or rounded at apex, 8.5-15 $\times 2.3-5 \mathrm{~cm}$; sheaths tubular, 1-3 cm long. Inflorescence erect, laxly 8-20-flowered, 20-35 cm long; bracts ovate-triangular, acute, 1.5-3 mm long. Flowers greenish yellow or yellow with reddish stripes on lip, not opening widely; pedicel and ovary $2.5-3 \mathrm{~cm}$ long. Dorsal sepal narrowly oblong-lanceolate, acute, ca. 3-3.8 $\times 5 \mathrm{~mm}$. Lateral sepals obliquely lanceolate, acute, $3.2-4 \times 0.5-0.6 \mathrm{~cm}$; mentum obliquely conical, $7-8 \mathrm{~mm}$ long. Petals narrowly oblong-oblanceolate, acute, $3.2-4 \times 0.4-0.6 \mathrm{~mm}$, untwisted. Lip 3-lobed in apical half, 2.6-3.2 $\times 0.9-1.2 \mathrm{~cm}$; side lobes narrowly oblong, erect, somewhat erose on front margins; midlobe ovate, acute, 1.5-1.8 $\times 1-1.3 \mathrm{~cm}$, with an obscurely erose margin; callus of 3 longitudinal lamellae from base on basal half of midlobe, each raised into a flap at apex. Column 3-4 mm long; foot 6.5-7.5 mm long. Section Spathulata. No Fig. available.

Distribution. Tonga ('Eua, Vava'u, Niuafo'ou, Niuatoputapu, and Tafahi). Also in Fiji. НАвітAт. Occasional in littoral to lowland forest; near sea level to $80 \mathrm{~m}$.

Collections. 'Eua: Lister s.n. Niuafo'ou: Buelow 1934; Whistler 6432. Vava'u: Hotta 4997; Soakai 1043; Yuncker 16202. Niuatoputapu: Buelow 1075, 1114; Kirch 313. Tafahi: Buelow 1259, 1288; Hurlimann 462.

\section{Bulbophyllum}

Thouars, Hist. Orchid.: t. 3 sub u. 1822.

Small to large, epiphytic or lithophytic herbs (or very rarely terrestrial) with short- to long-creeping rhizomes and pseudobulbous stems (or pseudobulbs rarely almost absent), unifoliate (or sometimes bifoliate outside our region) at apex. Leaf coriaceous to chartaceous, rarely deciduous. Inflorescence solitary or fasciculate, lateral from base of pseudobulb or from rhizome, one- to many-flowered, racemose, subumbellate or subcapitate. Flowers small to relatively large and showy, sessile to long-pedicellate. Dorsal sepal free or rarely adnate to lateral sepals. Lateral sepals adnate to column-foot at base to form a more or less prominent mentum, free or partly connate above. Petals free, narrower than sepals. Lip articulate to column-foot, mobile, rarely not, entire to 3-lobed, often very fleshy and recurved, often ciliate or pubescent, usually with a callus. Column short, with a more or less prominent foot; pollinia two or four, waxy, usually coherent in two pairs.

A large genus of possibly 1500 species found throughout the tropics and subtropics, but best represented in S.E. Asia and Malesia. Six species are reported from the study area: three from Tonga only, one from Niue only, one from the Cook Islands, and one from both Tonga and Niue.

\section{Key to Species (excluding sp. No. 6)}

1. Inflorescences one-flowered

2. Pseudobulbs distant on a slender rhizome

2. Pseudobulbs distichously and proximally arranged

1. B. rostriceps

1. Inflorescence two or more-flowered 
2. Flowers borne simultaneously in a subumbel; lateral sepals much longer than the dorsal sepal and fused in apical half

2. Flowers borne in succession in an elongated raceme

3. Petals acuminate, ca. $2 \mathrm{~mm}$ long; lip with two erect, horn-like appendages near base

3. Petals acute, $12-16 \mathrm{~mm}$ long; lip lacking horn-like appendages near base

1. Bulbophyllum rostriceps Rchb. f., Otia Bot. Hamburg. 55 (1878). Type: Fiji, USEE s.n. (holotype $\mathrm{W}$ !, isotype AMES!).

Creeping epiphytic herb with an elongate rhizome and cylindrical-ovoid pseudobulbs $1-1.8 \mathrm{~cm}$ long, $0.3-$ $0.5 \mathrm{~cm}$ in diameter, borne $2.5-9.5 \mathrm{~cm}$ apart, unifoliate at apex. Leaves erect, elliptic-ligulate, obtuse, 2.6-5.6 $\times$ $0.6-1.3 \mathrm{~cm}$, shortly petiolate. Inflorescence $2-5.5 \mathrm{~cm}$ long, bearing a solitary flower; scape filiform, up to 4.5 $\mathrm{cm}$ long; bract clasping, small, ovate-cucullate, ca. $1 \mathrm{~mm}$ long. Flower purple-maroon; pedicel and ovary ca. 8 $\mathrm{mm}$ long, ovary 6-angled. Dorsal sepal narrowly elliptic-ovate or ovate, acuminate, 4-5 × 1.5-2 mm. Lateral sepals oblong-ovate to ovate, oblique, acuminate, $4.5-5.5 \times 2-2.4 \mathrm{~mm}$. Petals obovate to elliptic-obovate, oblique, obtuse, 2-2.4 × 1.2-1.6 mm. Lip fleshy, porrect to slightly arcuate, oblong-ligulate, obtuse, 4-5.5 $\times$ 1.6-2.2 mm, glabrous or with a few scattered distal hairs; callus of two longitudinal ridges. Column ca. $1.8 \mathrm{~mm}$ long; stelidia attenuate to subulate; foot ca. $1 \mathrm{~mm}$ long. Section Ephippium. Fig. 55.

Distribution. Tonga (Kao and Tofua). Also found in Vanuatu, Fiji, and Samoa.

HABiтAT. Locally common in forests on volcanic islands; near sea level to $820 \mathrm{~m}$.

Collections. Kao: Buelow 651; Whistler 10703; Yuncker 15903. Tofua: Buelow 473, 479; Hotta 4354, 4405; Scarth-Johnson 151; Whistler 10612.

2. Bulbophyllum distichobulbum P.J. Cribb, Kew Bull. 50 (4): 787. 1995. Type: Samoa, Tutuila, Whistler 3757 (holotype BISH!).

Small epiphytic herb with a short ascending rhizome and distichously arranged, proximate, subspherical, angular pseudobulbs 4-5 $\mathrm{mm}$ in diameter. Leaves coriaceous, elliptic or elliptic-obovate, obtuse to subacute, 2.1-4 $\times 1-1.5 \mathrm{~cm}$. Inflorescence much longer than the leaf, one-flowered, glabrous; peduncle slender, filamentous, 5-5.5 cm long; bract sheathing, acute to acuminate, ca. $4 \mathrm{~mm}$ long. Flower yellow; pedicel and ovary 5-5.5 cm long. Dorsal sepal linear-lanceolate, acuminate, 11-14 × 1.5-2.1 mm. Lateral sepals obliquely lanceolate, acuminate, $14-14.5 \times 2-2.5 \mathrm{~mm}$. Petals transversely oblong, aristate at apex, ca. $3 \times 1 \mathrm{~mm}$. Lip fleshy, narrowly ellipsoidal, auriculate at base, rounded in front, ca. $4.5 \times 1.5 \mathrm{~mm}$, hairy; basal auricles erect; callus of two short ridges between auricles. Column ca. $2.5 \mathrm{~mm}$ long including ca. $1.5 \mathrm{~mm}$ long apical, aristate stelidia; foot swollen at base, ca. $1.5 \mathrm{~mm}$ long. Section Micromonanthe. Fig. 56.

Distribution. Niue. Also found in Samoa.

НАвітAт. Occasional in limestone forest; ca. 10-70 $\mathrm{m}$ on this island.

Collections. Niue: Sykes 347, 769, 878; Whistler 10765, 10840; Yuncker 9808, 9923.

Note. Closely related to the Fijian endemic species $B$. aristopetalum Kores, but having larger

flowers and a longer inflorescence overtopping the leaf.

3. Bulbophyllum longiflorum Thouars, Hist. Orchid.: 98 (1822). Type: Mauritius, Thouars s.n. (holotype P!). For full synonymy, see Lewis \& Cribb (1989).

Creeping epiphytic herb with a stout elongate rhizome bearing pseudobulbs at 5-6 $\mathrm{cm}$ intervals, these conical, 1.5-3.5 $\times 0.8-1.2 \mathrm{~cm}$, one-leafed at apex. Leaf erect, oblong, obtuse, 9-16 $\times 2-3.5 \mathrm{~cm}$; petiole 1.5-3 
$\mathrm{cm}$ long. Inflorescence suberect to spreading, 4-9-flowered in a false umbel, 12-30 cm long. Flowers elongate, creamy to yellow, blotched with red to purple, lip yolk-yellow to purple. Dorsal sepal concave, ovate, apically with long cilia, ca. $8 \times 4-5 \mathrm{~mm}$. Lateral sepals ligulate, fused in upper two-thirds, $2.5-3 \times 0.4-0.6 \mathrm{~cm}$. Petals ovate, ciliate, $0.6-0.9 \times 0.3-0.4 \mathrm{~cm}$. Lip fleshy, ligulate, $4-5 \times 2.5-3 \mathrm{~mm}$, recurved. Column ca. $3 \mathrm{~mm}$ long with apical down-curved stelidia; foot ca. 4 mm long. Section Cirrhopetalum. Fig. 57.

Distribution.Cook Islands (Rarotonga). A widespread species from tropical Africa, Madagascar, and S.E. Asia eastward to the Society Islands.

HAвітAт. Occasional in foothill to montane forest; elevation probably up to ca. $500 \mathrm{~m}$ or more.

Collections. Rarotonga: Cheeseman s.n.; Luttrell 353; Parks 22149, 22610; Philipson 10131; Sykes 1439, 1457, 1543, 2205; Whistler 4104, 5035, 5202; Wilder (published sight record).

4. Bulbophyllum longiscapum Rolfe, Bull. Misc. Inform. Kew 1896: 45 (1896). Type: Fiji, cult. Kew, Yeoward s.n. (holotype K!).

Bulbophyllum praealtum Kraenzl., Notizbl. Königl. Bot. Gart. Berlin 5: 109 (1909). Type: Samoa, Vaupel 322 (holotype B†, isotype K!).

Creeping epiphytic herb with an elongated rhizome $3-4.5 \mathrm{~mm}$ in diameter. Pseudobulbs widely spaced on rhizome, narrowly conical-ovoid, $2-4.5 \times 0.8-1.8 \mathrm{~cm}$. Leaf oblong-elliptic, broadly acute, 11.5-23 $\times$ 2-3.5 cm, petiolate. Inflorescence with several flowers produced in succession, erect-arcuate, racemose, 25-79 cm long; peduncle wiry, terete; rachis somewhat fractiflex; bracts broadly ovate, acuminate, 8-12 $\mathrm{mm}$ long. Flowers produced sequentially, white or greenish yellow marked with dull purple or red at base of segments; pedicel and ovary 10-15 mm long. Dorsal sepal lanceolate, acuminate, 25-30 × 5-5.5 $\mathrm{mm}$. Lateral sepals weakly spreading, obliquely lanceolate, attenuate, acute, $30-35 \times 6.5-7.5 \mathrm{~mm}$. Petals broadly ovate, acuminate, briefly setiform at apex, ca. $2 \times 1.5 \mathrm{~mm}$. Lip very fleshy, porrect, oblonglanceolate, narrowly obtuse, 26-32 × 8-9 mm; side margins revolute, crenate-undulate distally; callus of two prominently raised keels that coalesce in front. Column ca. $5 \mathrm{~mm}$ long; foot 7-8 $\mathrm{mm}$ long. Section Dialeipanthe. Figs. 58, 68.

Distribution.Tonga (Tafahi) and Niue. Also known from the Solomon Islands, Vanuatu, Fiji, Samoa, and Wallis Island.

НавітAт. Occasional in lowland to montane forest; near sea level to $500 \mathrm{~m}$.

Collections. Tafahi: Buelow 1172, 1184; Hurlimann 416; Whistler 6245. Niue: Sykes CHR 150587, 150588; Whistler 10769; Yuncker 9806.

5. Bulbophyllum pachyanthum Schltr., Bot. Jahrb. Syst. 39: 85 (1906). Type: New Caledonia, Schlechter 15678 (holotype B†).

Bulbophyllum longiscapum sensu Parham, Trans. Proc. Fiji Soc. 2: pl. 11 (1953), non Rolfe.

Bulbophyllum sp. 2 sensu Yuncker, Bernice P. Bishop Mus. Bull. 184: 33 (1945).

Large epiphytic herb with a clustered or weakly spreading habit, somewhat elongated rhizome 4-6 $\mathrm{mm}$ in diameter, and closely spaced, obliquely ovoid pseudobulbs $1.8-3.5 \times 1-1.7 \mathrm{~cm}$. Leaf oblong-elliptic, broadly acute, $8-22 \times 3-5.2 \mathrm{~cm}$, narrowly petiolate at base. Inflorescence erect, racemose, $22-40 \mathrm{~cm}$ long, laxly 2-4-flowered; peduncle slender, terete, bearing 3 or 4 widely spaced sheaths along its length; rachis short; bracts broadly ovate, acuminate, 10-12 mm long. Flowers developing sequentially, green or greenish yellow spotted with purple, glabrous; pedicel and ovary $1.5-2.5 \mathrm{~cm}$ long. Dorsal sepal narrowly ovate, acuminate, $2.2-2.8 \times 1.2-1.4 \mathrm{~cm}$, slightly thickened and carinate dorsally. Lateral sepals obliquely lanceolate, acute, $3.3-$ $3.8 \times 0.8-1.2 \mathrm{~cm}$, dorsally carinate. Petals obliquely ovate, acute, $1.2-1.6 \times 0.8-0.9 \mathrm{~cm}$. Lip arcuate, fleshy, 
oblong-lanceolate, subacute, $1.2-1.4 \times \mathrm{ca} .0 .5 \mathrm{~cm}$, auriculate at base; calli 2, longitudinal, somewhat papillate. Column ca. $1 \mathrm{~cm}$ long, with setose stelidia as long as the column; foot ca. $0.8 \mathrm{~cm}$ long. Section Dialeipanthe. Fig. 59.

Distribution.Tonga (Kao and Tofua). Also from New Caledonia, Fiji, and Samoa. Habitat. Uncommon in lowland to montane forest; 200 to ca. $1000 \mathrm{~m}$.

Collections. Kao: Buelow 672. Tofua: Buelow 480, 580; Hotta 4412; Scarth-Johnson 151; Whistler 10641.

\section{Bulbophyllum sp.}

A sterile specimen at Kew (Scarth-Johnston s.n.) collected on Tofua in Tonga does not fit any of the above species, nor any other that we have seen from the S.W. Pacific islands. It has small clustered pseudobulbs each bearing an oblong, shortly petiolate, erect leaf. Vegetatively it is similar to Bulbophyllum microrhombos from the Solomon Islands, but its leaves are more oblong and of a slightly different shape. The specimen may belong to sect. Hapalochilus but it bears no flowers or even old inflorescences.

\section{TAENIOPHYLLUM}

Blume, Bijdr. Fl. Ned. Ind.: 355. 1825.

Small to tiny acaulescent epiphytic herbs with terete to strongly dorso-ventrally flattened, greenish photosynthetic roots and very short stems bearing scales. Inflorescence erect, short to long, unbranched; peduncle and rachis glabrous or hairy; rachis often fractiflex. Flowers small, distichous, ephemeral or lasting a few days, pale green, yellow, or white. Sepals and petals free or fused in basal part to form a distinct perianth tube, apical parts free. Lip immobile, entire or 3-lobed, simple or with a retrorse bristle-like apex, spurred at base, the mouth often partially or entirely covered by a hyaline septum. Column short, lacking a foot; pollinia four, waxy, obovoid to ellipsoidal, attached by a slender stipe to a large viscidium.

A large genus of about 170 species in subtropical and tropical Asia and S.E. Asia, Malesia, New Guinea, the Philippines, Micronesia, N.E. Australia, New Caledonia, and the S.W. Pacific islands eastward to the Austral Islands and Pitcairn, with one species in tropical Africa. A single species is reported from Tonga, the Cook Islands, and Niue.

Taeniophyllum fasciola (Forst. f.) Seem., Bonplandia 10: 153. 1862; Rchb. f., Seem., Fl. Vit.: 296. 1868. Type: Tahiti, G. Forster 172 (holotype BM!, isotype P!).

Epidendrum fasciola Forst.f., Fl. Ins. Austr.: 60, n. 320. 1786.

Taeniophyllum asperulum Rchb.f., Otia Bot. Hamburg. 1: 53. 1878. Type: Society Islands, Wilkes s.n. (holotype W).

Taeniophyllum decipiens Schltr., Repert. Spec. Nov. Regni Veg. 9: 112. 1911. Type: Samoa, Vaupel 278 (holotype B†; isotypes AMES!, B, BISH!, K!, W!).

Taeniophyllum fasciola var. mutina N. Hallé, Fl. Nouv.-Caléd. 8: 386, pl. 157. 1977. Type: New Caledonia, McKee 29285 (holotype P!).

Taeniophyllum parhamiae L.O. Williams, Bot. Mus. Leafl. 7: 148. 1939. Type: Fiji, Parham 3 (holotype AMES!).

Taeniophyllum seemannii Rchb. f., Seem. Fl. Vit.: 296. 1868. Type: Fiji, Seemann 593 (holotype $\mathrm{W}$ !, isotype L!). 
Small, leafless epiphytic herb with long, flattened, spreading roots 10-30 $\times 2-5 \mathrm{~mm}$. Inflorescence short, densely few-flowered; peduncle and rachis densely verruculose; rachis fractiflex, $1-4 \mathrm{~cm}$ long; bracts ovate, ca. $1 \mathrm{~mm}$ long. Flowers pale yellowish white, with darker yellow tips to the perianth segments; ovary glandular pubescent. Sepals free, ovate- to ovate-elliptic, subacute, 2.5-4 × 1-2 mm. Petals free, ligulate or elliptic-ligulate, subacute, 2.5-4 $\times$ 0.5-1 mm. Lip entire, concave, navicular, 1.5-2.2 mm long; spur perpendicular to lip, short, subcylindrical to conical, subacute to obtuse, 1-2 mm long. Column very short; pollinia four, ellipsoidal to obovoid. Fig. 60.

Distribution. Tonga ('Eua, Tongatapu, Kao, Vava'u, Late, Niuafo'ou, Niuatoputapu, and Tafahi), the Cook Islands (Rarotonga, Mangaia, Atiu, Mauke, and Miti'aro), and Niue. Also in the Mariana Islands (Guam), the Solomon Islands, Vanuatu, New Caledonia, Fiji, the Horne Islands, Tahiti, the Austral Islands, and Pitcairn Island.

HaвiтAт. Common in coastal to lowland forest; near sea level to $300 \mathrm{~m}$.

Collections. 'Eua: Palmer 133; Sykes 255, 700; Whistler 7212, 7373. Tongatapu: Buelow 143, 1788; Hotta 4035, 4113, 4282; Hurlimann 88; Parks 15642; Yuncker 15019, 15228, 16207. Kao: Buelow 719. Vava'u: Buelow 1473; Hotta 5691. Late: Buelow \& Sykes 157; Hotta 4804. Niuafo'ou: Buelow 1976; Whistler 6431. Niuatoputapu: Buelow 1358; Kirsch 309. Tafahi: Buelow 1251. Rarotonga: Cheeseman 679; Given 1437; Luttrell \& McCormack 164, 165; Parks 22103; Philipson 10124; Sykes 918, 1565, 2182; Whistler 4065; Wilder 8507. Mangaia: Sykes 501; Whistler 5391. Atiu: Sykes 364; Whistler 5283. Mauke: Paulay 390; Sykes 2467; Whistler 5556. Miti'aro: Whistler 5917. Niue: Sykes 328; Whistler 10768; Yuncker 9596.

\section{RoBIQUETIA \\ Gaudichaud, Voy. Uranie 426, t. 34 (1826).}

Epiphytic herbs with stout, elongate, pendent stems. Leaves distichous, coriaceous, several. Inflorescences several, lateral, more or less clavate, thick, densely many-flowered, racemose. Flowers non-resupinate, more or less campanulate, small but often brightly colored, red, orange, or pink. Sepals and petals free, subsimilar. Lip very fleshy, entire or obscurely 3-lobed, spurred at the base; spur clavate. Column short; pollinia two, joined by a strap-shaped stipe to a common viscidium.

A genus of about 35 species in India, S.E. Asia, and the Malay Archipelago, east to the Philippines and the S.W. Pacific islands. A single species is found in Tonga.

Robiquetia tongaensis P.J. Cribb \& Ormerod, Kew Bull. 60, 4: 609. 2006. Type: Tonga, 'Eua, Whistler 7014 (holotype BISH!).

Epiphytic herb with a short stem up to $8 \mathrm{~cm}$ or more in length. Leaves thick, coriaceous-fleshy, oblong, bilobed at the tip, 9-23 $\times 2-3.5 \mathrm{~cm}$, with undulate margins. Inflorescence of short, curved, axillary racemes up to $8 \mathrm{~cm}$ long, densely many-flowered; rachis rather fleshy; bracts small, triangular. Flowers more or less campanulate, white to dark pink with greenish sepal tips. Sepals oblong, subacute to obtuse, $4-5 \times 2-3 \mathrm{~mm}$. Petals oblong, obtuse, ca. $4.5 \times 2.5 \mathrm{~mm}$. Lip very fleshy, triangular, acute, ca. $4 \times 2 \mathrm{~mm}$, with upcurved sides; spur clavate, 4-5 mm long, geniculate at the base and parallel to the column. Column somewhat tapering from base, then abruptly clavate at apex, ca. $2.5 \mathrm{~mm}$ long; rostellum with two deflexed hatchet-shaped, apical wings acute in front; pollinia attached to a spathulate, convex, curved stipe and a single large cordate viscidium. Capsule cylindrical, ridged, ca. $2 \mathrm{~cm}$ long. Fig. 61.

Distribution. Tonga ('Eua and Tongatapu). Endemic to Tonga.

Haвiтat. Common in littoral to foothill forest, sometimes on Tournefortia and Terminalia; near sea level to $250 \mathrm{~m}$. 
Collections. 'Eua: Buelow 1710, 1761; Hotta 5209, 5252, 5363, 5432; Sykes 392; Whistler 6002, 7104; Yuncker 15408, 15550, 15571. Tongatapu: Buelow 2291; Hotta 4018; Parks 15179, 15279.

\section{TUBEROLABIUM}

Yamamoto, Bot. Mag. (Tokyo) 38: 209. 1924.

Small epiphytic herbs with short unbranched stems bearing distichous coriaceous leaves. Leaves articulated to a sheathing base, ligulate to elliptic-ligulate. Inflorescence patent or pendulous, lateral, abbreviated, densely few-flowered. Flowers small, membranous. Sepals subsimilar, free. Petals smaller than sepals, free. Lip immobile, weakly 3-lobed, fleshy, somewhat concave, shortly spurred or saccate at base. Column lacking a column-foot; pollinia two, waxy, globose, attached by a common stipe to a large viscidium.

A small genus of about 12 species, widespread from India and S.E. Asia eastward to Taiwan, N.E. Australia, and the S.W. Pacific islands. A single species is found in the Cook Islands and Niue.

Tuberolabium papuanum (Schltr.) J.J. Wood ex B.A. Lewis \& P.J. Cribb, Orchids Vanuatu: 150. 1989. Types: New Guinea, Schlechter 17166, 18975 (syntypes B†).

Saccolabium papuanum Schltr., Repert. Spec. Nov. Regni Veg. Beih. 1: 978 (1913). For full synonymy, see Kores (1991).

Trachoma papuanum (Schltr.) M.A. Clem., J.J. Wood \& D.L. Jones, Austral. Orchid Res. 145 (1989).

Trachoma societatas (J.W. Moore) N. Hallé, Orchidophile (Asnières) 40: 1481. 1980.

Small epiphytic herb $2-5 \mathrm{~cm}$ in height, with terete stems completely covered by distichous leaf sheaths. Leaves very fleshy, ligulate to elliptic-ligulate, often somewhat falcate, 2.6-6 $\times 0.9-1.6 \mathrm{~cm}$; sheaths striate, inflated. Inflorescence subdensely few-flowered, $0.8-1.5 \mathrm{~cm}$ long; peduncle 1-2 mm long; bracts deltoid, ca. $1.5 \mathrm{~mm}$ long. Flowers pale yellow. Dorsal sepal oblong-ovate to oblong-elliptic, 4.5-5.5 × 1.5-2.2 mm. Lateral sepals obliquely oblong-ovate, $4.5-5.5 \times 2.5-3 \mathrm{~mm}$. Petals oblong-ligulate, $4-5 \times 1.5-2.2 \mathrm{~mm}$. Lip closely appressed to column, somewhat concave, bilaterally compressed, $3.5-4 \mathrm{~mm}$ long; side lobes erect, broader than long; midlobe porrect, transversely ovate, very fleshy; spur subcylindrical, ca. $1.5 \mathrm{~mm}$ long. Column 1.2-2 mm long. No Fig. available.

Distribution. Cook Islands (Rarotonga) and Niue. Also in New Guinea, Queensland, the Solomon Islands, Fiji, the Australs, and the Society Islands.

НавітAт. Occasional in forest on upper terrace; ca. 65-600 m.

Collections. Rarotonga: Cheeseman s.n.; Sykes 2200, 2208; Whistler 5036; Wilder (published sight record). Niue: Sykes 287, 698, 880, CHR 150580; Yuncker 9929.

\section{EuLOPHIA}

R. Br. ex Lindl., Bot. Reg. 8: t. 686. 1823.

Terrestrial herbs with small several-noded pseudobulbs. Leaves 2-several, erect or suberect, pleated. Inflorescence erect, densely to laxly few- to many-flowered, racemose. Flowers medium-sized, to large, often showy. Sepals and petals subsimilar, free. Lip usually 3- or 4-lobed, rarely entire, spurred at base, callus usually present. Column short to elongate, with a short foot; pollinia four, attached by a short stipe to a sickle-shaped viscidium.

A large genus of about 250 species, widespread from Africa south of the Sahara, Madagascar to tropical Asia, the Malay Archipelago, N.E. Australia, and the S.W. Pacific. Two species are found in Tonga, one of them also in Niue. 


\section{Key to Species}

1. Flowers more or less white; lip entire or very obscurely 3-lobed

1. Eulophia spectabilis (Dennst.) Suresh, D.H. Nicholson et al., Interpret. Van Rheede's Hort. Malab.: 300. 1988.

Eulophia nuda Lindl., Gen. Sp. Orchid. Pl. 180. 1833.

Wolfia spectabilis Dennst., Schlüssel Hort. Malab.: 38 (1818). Based upon Rheede's Hort. Malabar.: 11: 71, t. 36. 1692. For full synonymy, see Suresh reference.

Medium-sized terrestrial herb up to $75 \mathrm{~cm}$ in height. Leaves erect, 2 or more, plicate, elliptic-lanceolate, acuminate, up to $44 \times 3-3.5 \mathrm{~cm}$. Inflorescence erect, 28-80 cm long, 2-10-flowered; peduncle and rachis stout, up to $5 \mathrm{~mm}$ diameter. Flowers showy, probably self-pollinating, white to greenish white; pedicels ca. 2.5 cm long. Sepals lanceolate, acute, 2.2-2.5 cm long. Petals ovate, acute, $1.8-2 \mathrm{~cm}$ long. Lip ovate to oblong, entire, 1.8-2 × ca. $1 \mathrm{~cm}$; spur broad, flattened, 2-3 mm long, recurved. Capsule nodding, ribbed. Column stout, clavate, $9-11 \mathrm{~mm}$ long, winged near the base. Fig. 62.

Distribution. Tonga (Kao and Tofua). Widespread from India and Sri Lanka eastward to the S.W. Pacific to Yap, Fiji, and Tonga.

HaвiтAт. Uncommon in forests; near sea level to $80 \mathrm{~m}$.

Collections. Kao: Buelow 2829. Tofua: Buelow 469. Without exact locality: Lister s.n.?

2. Eulophia pulchra (Thouars) Lindl., Gen. Sp. Orchid. P1.: 182. 1833. Type: Mauritius, Thouars s.n. (holotype P).

Eulophidium pulchrum (Thouars) Summerh., Bull. Jard. Bot. État 27: 400. 1957. See Lewis \& Cribb (1989) for other relevant synonymy.

Medium-sized terrestrial herb up to $50 \mathrm{~cm}$ in height. Pseudobulbs cylindrical, 6-10 cm long, 2-3-leafedleaved at apex. Leaves suberect, broad, plicate, elliptic, acuminate, 18-28 $\times 4.5-7 \mathrm{~cm}$; petiole articulated in middle, up to $10 \mathrm{~cm}$ long. Inflorescence a terminal raceme $40-75 \mathrm{~cm}$ long. Flowers green and yellow with red stripes on lip. Sepals ovate, 8-10 mm long. Petals narrower, 7-9 mm long. Lip 4-lobed with a small basal, bilobed callus; spur short, globular, ca. 3 mm long. Fig. 63 .

Distribution. Tonga (Kao, Vava' $u$, and Late) and Niue. Widespread from tropical Africa and Madagascar eastward to S.E. Asia, the Malay Archipelago, and the S.W. Pacific islands eastward to Niue.

НавітAт. Uncommon to rare in forests and open places; near sea level to ca. $200 \mathrm{~m}$.

Collections. Kao: Buelow 2830. Vava'u: Whistler 6572. Late: Buelow \& Sykes 71. Niue: Sykes $378,747$.

\section{GeOdorum}

Jackson, Bot. Repos. 10: t. 626. 1811.

Terrestrial herbs with short subterranean rhizomes and erect, partially subterranean, one-noded pseudobulbs, leafy at apex. Leaves few, pleated, articulated, petiolate, deciduous. Inflorescence basal, racemose, croziershaped at anthesis but straightening and elongating after fruit set, laxly to densely few- to many-flowered; rachis much shorter than peduncle. Flowers often showy, medium-sized, non-resupinate. Sepals and petals free, dissimilar, more or less connivent. Lip sessile, continuous with column-foot, subentire, saccate or ventricose at 
base, with or without a callus. Column short, broad, with a foot; pollinia two, waxy, sulcate, attached by a short stipe to a distinct viscidium.

A genus of perhaps 10 species in subtropical and tropical Asia and S.E. Asia, Malesia, New Guinea, the Philippines, Micronesia, N.E. Australia, the Solomon Islands, Vanuatu, New Caledonia, Fiji, Tonga, Niue, and Samoa. A single species is found in Tonga and Niue.

Geodorum densiflorum (Lam.) Schltr., Repert. Spec. Nov. Regni Veg. Beih. 4: 259. 1919. Type: based on Rheede, Hort. Ind. Malabar. 11: 69, t. 35, (1692).

Cymbidium pictum R.Br., Prodr. Fl. Nov. Holl.: 331. 1810. Type: Australia, R. Brown 5507 (holotype BM!).

Geodorum furcatum sensu Kraenzl., Bot. Jahrb. Syst. 25: 60. 1898, non Lindl.

Geodorum neocaledonicum Kraenzl., Vierteljahrsschr. Naturf. Ges. Zürich 74: 82. 1929. Type: New Caledonia, Daeniker 1384 (holotype Z!).

Geodorum pacificum Rolfe, Bull. Misc. Inform. Kew 1908: 71. 1908. Types: Tonga, Vava'u, Crosby 246 (syntype K!); Solomon Islands, Woodford s.n. (syntype K!).

Geodorum pictum (R. Br.) Lindl., Gen. Sp. Orchid. Pl.: 175 (1833).

Geodorum tricarinatum Schltr., Repert. Spec. Nov. Regni Veg. 9: 101. 1911. Type: Samoa, Savai'i, Vaupel 285 (holotype B†), nom. nov. pro G. furcatum Kraenzl., non Lindl.

Limodorum densiflorum Lam., Encycl. 3: 516. 1792.

Terrestrial herb $20-50 \mathrm{~cm}$ in height, with clustered, subglobose pseudobulbs $1.3-2.6 \mathrm{~cm}$ in diameter covered by scarious sheaths when young. Leaves $2-5$, ovate to elliptic-ovate, acute or acuminate, $18-40 \times$ 4.5-7 cm; petiole sheath-like, 6-18 cm long; the lowermost 2 sheath-like, acute. Inflorescence more or less as long as leaves; peduncle erect; rachis recurved; bracts linear lanceolate, 1-1.3 cm long. Flowers pale pinkish white to pale purple with reddish marks and yellow blotches on lip; ovary 5-9 mm long. Sepals oblongobovate, abruptly acuminate, $10-12 \times 3-3.5 \mathrm{~mm}$. Petals oblong to oblong-elliptic, obtuse to subacute, 9.5-11 $\times 3.5-4.5 \mathrm{~mm}$. Lip cymbiform, slightly constricted in middle, weakly bilobed at apex, saccate at base, 11-13 $\times$ 10-12 mm; callus a small transverse ridge at base and warts or keels in front. Column ca. $3 \mathrm{~mm}$ long; foot ca. 3 mm long. Fig. 64 .

Distribution. Tonga (Tongatapu, Ha'apai, Kao, Tofua, Vava'u, Niuafo'ou, Niuatoputapu, and Late) and Niue. Also found in southern China, Burma, India, Ceylon, the southern Ryukyu Islands, New Guinea, northern Australia, the Bismarck Archipelago, the Solomon Islands, Vanuatu, New Caledonia, Fiji, and Samoa.

НАвітAт. Uncommon in grassy areas, fern communities, and lowland forest; near sea level to $40 \mathrm{~m}$. Collections. Tongatapu: Hotta 4099; USEE s.n.; Yuncker 15295. Ha'apai: Buelow 296, 304; Hurlimann 260; Whistler 6649; Yuncker 15863. Kao: Buelow 731, 3112; Whistler 10692. Tofua: Buelow 528, 529, 2613. Vava'u: Buelow 1648; Crosby 246; Whistler 6008; Yuncker 16051. Late: Buelow \& Sykes 159; Hotta 4810. Niuafo'ou: Buelow 2114, 2167, 2220. Niuatoputapu: Whistler 6168. Niue: Sykes CHR 150576; Yuncker 10098. 

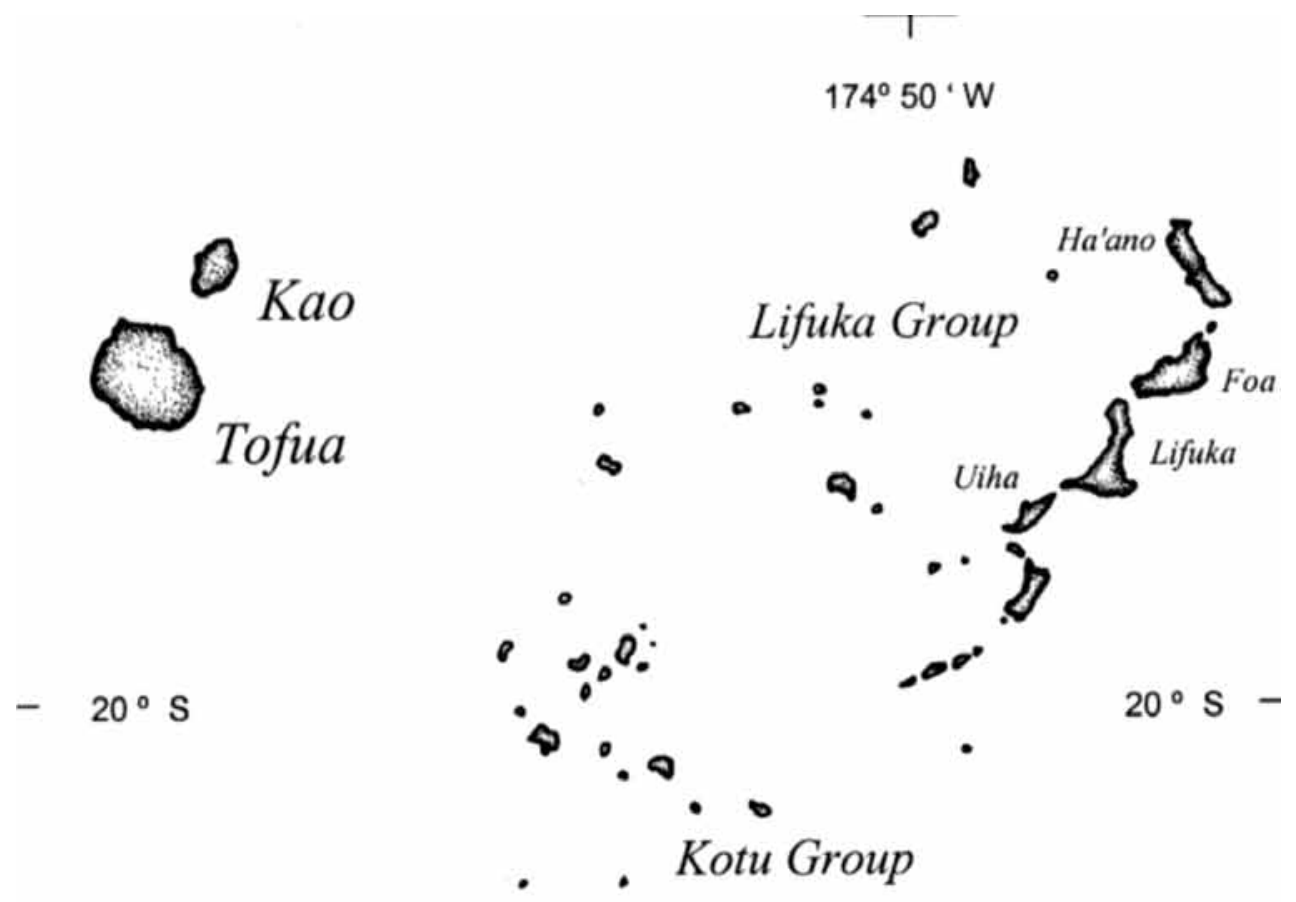

Nomuka

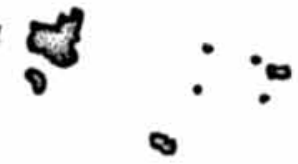

Nomuka Group

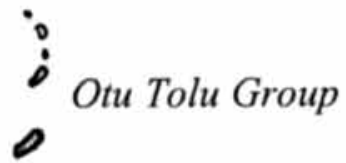

\section{Central TONGA GROUP (Ha' apai Group)}

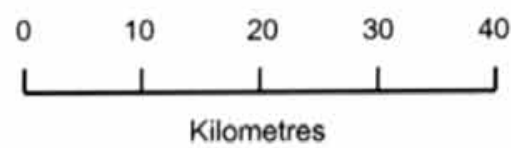

$174^{\circ} 50^{\circ} \mathrm{W}$ 


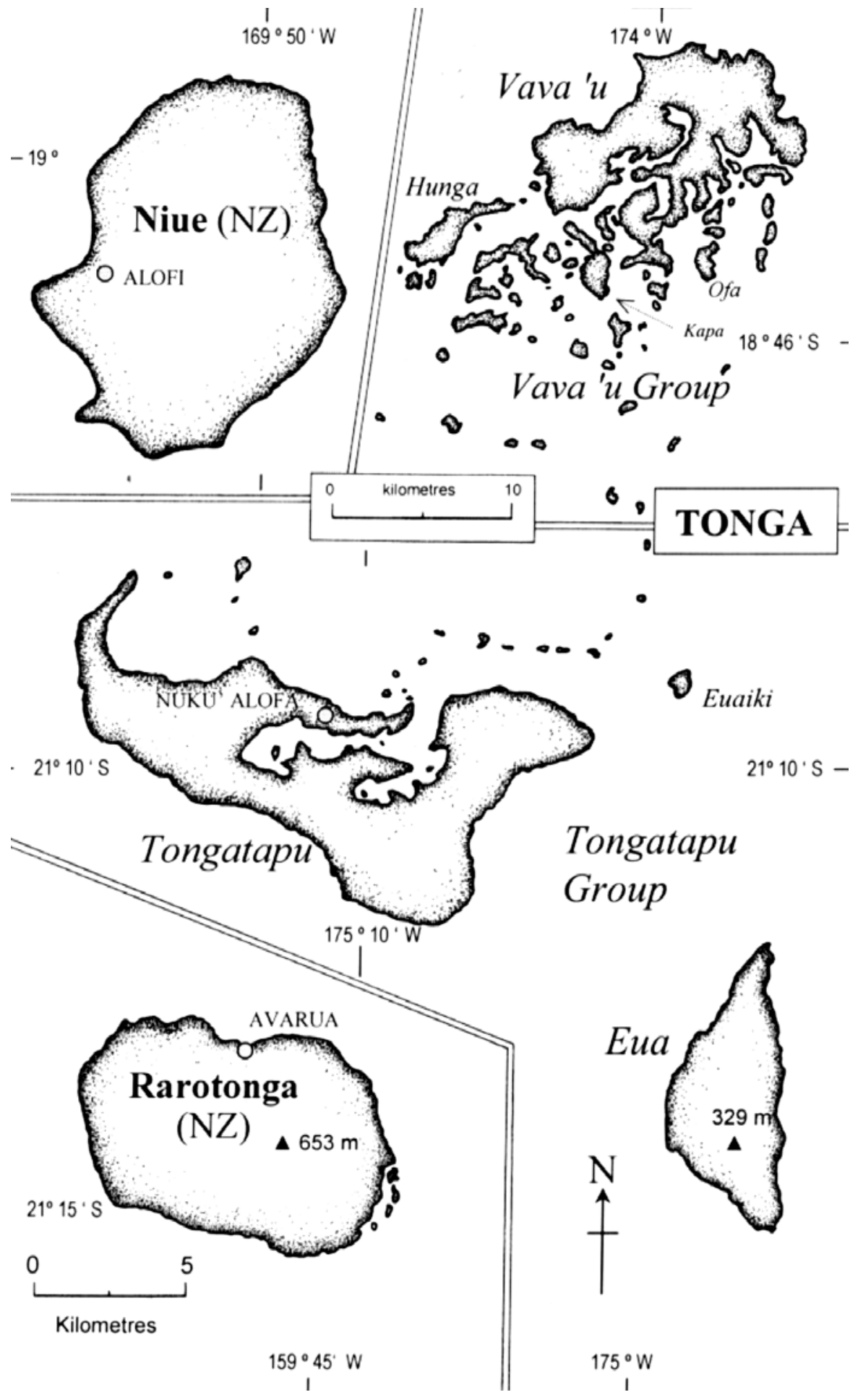

Figure 66. Map of Rarotonga, Tongatapu, Eua, Vava'u, and Niue. 


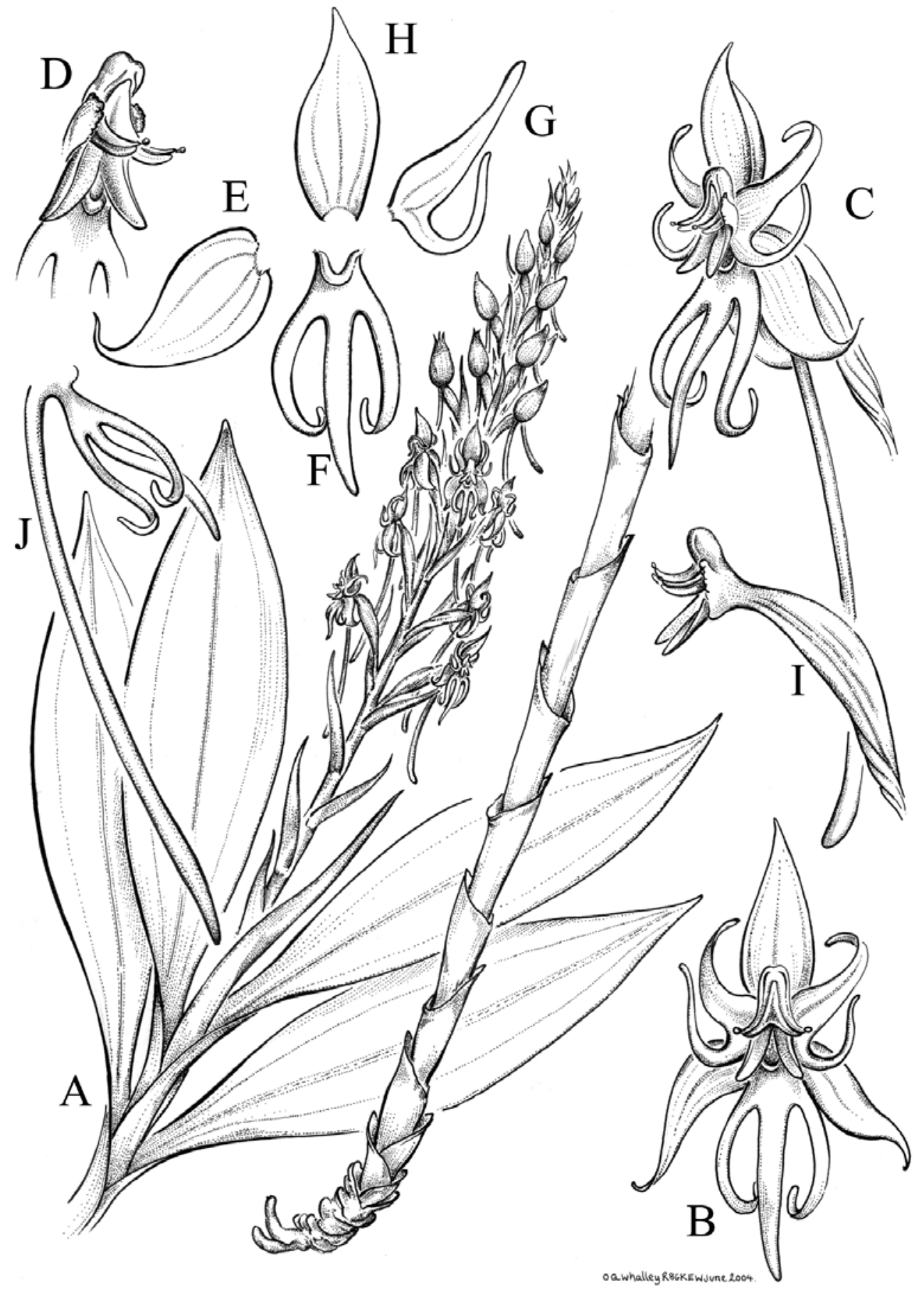

Figure 67. Habenaria amplifolia. A - Plant habit. B - Flower from front. C - Flower from side. D - Column. E - Lateral sepal. F - Labellum without spur. G - Petal. H - Dorsal sepal. I - Column and ovary. J - Labellum with spur. 


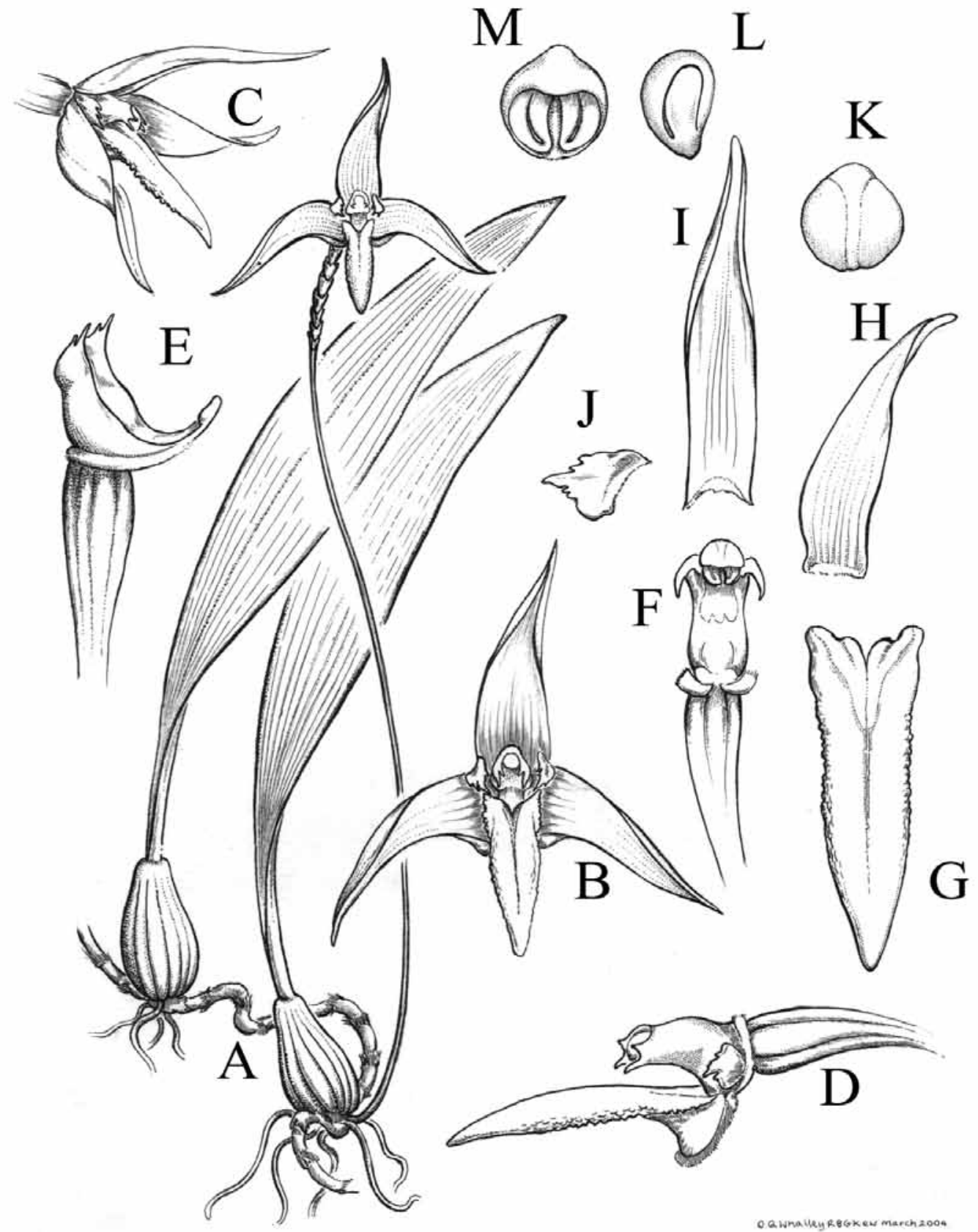

FiguRE 68. Bulbophyllum longiscapum. A - Plant habit. B - Flower from front. C - Flower from side. D - Flower with sepals removed, from side. E - Column and ovary with anther cap removed. F - Column and ovary from front. G - Labellum from above. H - Lateral sepal. I - Dorsal sepal. J - Petal. K - Top of anther cap. L - Pollinium from side. M - Anther cap (below) with pollinia in place. 


\section{REFERENCES}

Burkill, I.H. 1901. The flora of Vavau, one of the Tonga Islands. J. Linn. Soc., Bot. 35: 20-65.

Chase, M.W., K.M. Cameron, R.L. Barrett \& J.V. Freudenstein. 2003. DNA data and Orchidaceae systematics: a new phylogenetic classification. In Dixon, K.W., S.P. Kell, R.L. Barrett, \& P.J. Cribb, eds. Orchid Conservation: 69-89. Natural History Publications, Kota Kinabalu, Sabah.

Cheeseman, T.G. 1903. The flora of Rarotonga, the chief island of the Cook group. Trans. Linn. Soc. London, Bot. (6): 261-323.

Cribb, P.J. \& W.A. Whistler. 1996. Orchids of Samoa. Royal Bot. Gardens, Kew. 141 pp.

Drake, D.R., W.A. Whistler, T.J. Motley \& C.T. Imada. 1996. Rain forest vegetation of 'Eua Island, Kingdom of Tonga. New Zealand J. Bot. 34: 65-77.

Ellison, J.C. 1990. Vegetation and floristics of the Tongatapu outliers. Atoll Res. Bull. 332: 1-35.

Franklin, J. \& M. Merlin. 1992. Species-environment patterns of forest vegetation on the uplifted reef limestone of Atiu, Mangaia, Ma'uke and Miti' ${ }^{`}$ aro, Cook Islands. J. Veg. Sci. 3: 3-13.

Frost, I.A. \& N.R. Berryman. 1966. Timber resources of Niue Island. Unpublished internal report prepared by the New Zealand Forest Service. 25 pp.

Garay, L.A. \& H.R. Sweet. 1974. Orchids of the southern Ryukyu Islands. Harvard Univ. Press. 180 pp.

Hallé, N. 1977. Orchidées. In Flore de Nouvelle Calédonie et Dépendences. Muséum National d'Histoire Naturelle. Paris. 565 pp.

Hallé, N. 1980. Les Orchidées de Tubua ‘i (Archipel des Australes, Sud Polynésie). Cahiers de l'Indo-Pacifique 2 (3): 69-85.

Hallé, N., D.L. Szlachetko, P. Rutkowski \& H.B. Margońska. 1998. Distribution of the orchids in West and South-West Pacific islands - a preliminary report 1998. Fragm. Florist. Geobot. 43: 39-88.

Hemsley, W.B. 1894. The flora of the Tonga or Friendly Islands, with descriptions of and notes on some new or remarkable plants... J. Linn. Soc., Bot. 30: 158-217.

Hotta, M. 1962. Flora of Tonga: a study of Tongan plants. Unpublished Ms. 268 pp.

Kores, P. 1991. Orchidaceae. In Smith, A.C. ed., Flora Vitiensis Nova 5: 322-575. NTBG, Kaua‘i, HI.

Lewis, B. \& P.J. Cribb. 1989. Orchids of Vanuatu. Royal Bot. Garden, Kew. 171 pp.

Lewis, B.A. \& P.J. Cribb. 1991. Orchids of the Solomon Islands and Bougainville. Royal Bot. Garden, Kew. $335 \mathrm{pp}$.

Merlin, M.D. 1985. Woody vegetation in the upland region of Rarotonga, Cook Islands. Pacific Sci. 39 (1): 81-99.

Merlin, M.D. 1991. Woody vegetation on the raised coral limestone of Mangaia, southern Cook Islands. Pacific Sci. 45 (2): 131-151.

Mueller-Dombois, D. \& F.R. Fosberg. 1998. Vegetation of the tropical Pacific Islands. Springer-Verlag, Inc., New York, NY. 733 pp.

Niue Forestry Section. 1990. The natural forest of Niue Island: merchantable forest survey. Department of Agriculture, Forestry, and Fisheries. 43 pp.

Palmer, M.W. 1988. The vegetation and anthropogenic disturbance of Toloa forest, Tongatapu Island, South Pacific. Micronesica 21: 279-281.

Park, G. \& W.A. Whistler. 2001. The terrestrial ecology and botany of Tofua and Kao islands in Ha'apai, Kingdom of Tonga: a survey of biodiversity conservation. South Pacific Biodiversity Conservation Programme, Apia, Samoa. 180 pp.

Pickering, C. 1876. The geographical distribution of animals and plants in their wild state. Pp. 312-25. (From USEE 19[2]). Naturalists Agency, Salem, MA.

Pridgeon, A.M., P.J. Cribb, M.W. Chase \& F. Rasmussen, eds. 1999. Genera Orchidacearum I. Oxford University Press.

Pridgeon, A.M., P.J. Cribb, M.W. Chase \& F. Rasmussen, eds. 2001. Genera Orchidacearum II. Oxford University Press. 
Pridgeon, A.M., P.J. Cribb, M.W. Chase \& F. Rasmussen, eds. 2003. Genera Orchidacearum III. Oxford University Press.

Pridgeon, A.M., P.J. Cribb, M.W. Chase \& F. Rasmussen, eds. 2005. Genera Orchidacearum IV. Oxford University Press.

Rasmussen, F.N. 1977. The genus Corymborkis (Orchidaceae). A taxonomic revision. Bot. Tidsskr. 71: 161192.

Seemann, F. 1868. Flora Vitiensis. L. Reeve, London.

Smith, S.P. 1902. Niue and its people. J. Polynes. Soc. 11: 80-106.

Steadman, D.W., J. Franklin, D.R. Drake, H.B. Freifeld, L.A. Bolick, D.S. Smith \& T.J. Motley. 1999A. Rain forest composition and patterns of secondary succession in the Vava' $u$ island group, Tonga. J. Veg. Sci. 10: $51-64$.

Steadman, D.W., J. Franklin, D.R. Drake, H.B. Freifeld, L.A. Bolick, D.S. Smith \& T.J. Motley. 1999B. Conservation status of forests and vertebrate communities in the Vava' $u$ island group, Tonga. Pac. Conservation Biol. 5: 191-207.

St. John, H. 1976. A plant collection from Niue Island by Jensen in 1876. Bot. Mag. (Tokyo) 89: 235-240.

St. John, H. 1977. The flora of Niuatoputapu Island, Tonga. Pacific Plant Studies 32. Phytologia 36 (4): 374-90.

Stoddart, D.R. 1972. Reef islands of Rarotonga, with a list of the vascular flora by F.R. Fosberg. Atoll Res. Bull. 160: 1-14.

Stoddart, D.R. 1975A. Vegetation and floristics of the Aitutaki motus. In Stoddart, D.R. \& P.E. Gibbs, eds. Almost-atoll of Aitutaki: reef studies in the Cook Islands. Atoll Res. Bull. 190: 87-116.

Stoddart, D.R. 1975B. Mainland vegetation of Aitutaki. In Stoddart, D.R. \& P.E. Gibbs, eds. Almost-atoll of Aitutaki: reef studies in the Cook Islands. Atoll Res. Bull. 190: 87-116.

Straatsmans, W. 1964. Dynamics of some Pacific island forest communities in relation to the survival of the endemic flora. Micronesica 1: 113-122.

Sykes, W.R. 1970. Contributions to the flora of Niue. New Zealand Dept. Sci. and Industr. Res. Bull. 200: $1-321$.

Sykes, W.R. 1977. The pteridophytes of 'Eua, Southern Tonga. Bull. Roy. Soc. New Zealand 17: 119-152.

Sykes, W.R. 1981. The vegetation of Late, Tonga. Allertonia 6 (2): 323-353.

Takhtajan, A.L. 1969. Flowering plants: origin and dispersal. Oliver and Boyd, Edinburgh. 310 pp.

Uhe, G. 1974. The composition of the plant communities inhabiting the recent volcanic ejecta of Niuafo'ou, Tonga. Trop. Eco. 15 (1 \& 2): 126-138.

Whistler, W.A. 1984. Notes on the flora of Niue. New Zealand J. Bot. 22: 565-567.

Whistler, W.A. 1992. Vegetation of Samoa and Tonga. Pacific Sci. 46 (2): 159-178.

Whistler, W.A. \& J. Atherton. 1997. Botanical survey of the Huvalu forest conservation area: Niue. South Pacific Biodiversity Conservation Programme, Apia, Samoa. 76 pp.

Wilder, G.P. 1931. Flora of Rarotonga. Bernice P. Bishop Mus. Bull. 86: 1-113.

Wiser, S.K., D.R. Drake, L.E. Burrows \& W.R. Sykes. 2002. The potential for long-term persistence of forest fragments on Tongatapu, a large island in western Polynesia. J. Biogeogr. 29: 767-787.

Wright, A.C.S. \& F.J. van Westerndorp. 1965. Soils and agriculture of Niue Island. New Zealand Dept. Sci. and Industr. Res., Soil Bur. Bull. 17: 1-80.

Yuncker, T.G. 1943. The flora of Niue Island. Bernice P. Bishop Mus. Bull. 178: 1-126.

Yuncker, T.G. 1959. Plants of Tonga. Bernice P. Bishop Mus. Bull. 220: 1-283. 
LANKESTERIANA 


\section{INDEX TO SCIENTIFIC NAMES}

Valid species names and genera are in bold italics, synonyms are in normal

\section{Acanthephippium Blume}

A. papuanum Schltr.

A. splendidum J.J. Sm.

Adenostylis Blume

A. stricta Rolfe

A. vitiensis Rolfe

Aetheria oblongifolia (Blume) Lindl.

Appendicula Blume

A. reflexa Blume

Bletia angustifolia Gaudich.

Bulbophyllum Thouars

B. aristopetalum Kores

B. distichobulbum P.J. Cribb

B. longiflorum Thouars

B. longiscapum Rolfe

B. longiscapum sensu Parham

B. pachyanthum Schltr.

B. praealtum Kraenzl.

B. rostriceps Rchb.f.

B.sp.

B. sp. 2 sensu Yuncker

Calanthe $\mathrm{R}$. Br.

C. angraeciflora Rchb. f.

C. furcata sensu Yuncker

C. hololeuca Rchb. f.

C. neocaledonica Rendle

C. nephroglossa Schltr.

C. triplicata (Willemet) Ames

C. triplicata var. angraeciflora (Rchb. f.) N. Hallé

C. vaupeliana Kraenzl.

C. veratrifolia (Willd.) R. Br.

Cestichis gracilis (Hook.f.) Ames

Cheirostylis sp. sensu Yuncker

Corymbis Thouars in Seem.

Corymborchis Blume

Corymborkis Thouars

C. veratrifolia (Reinw.) Blume

Crepidium Blume

C. brevidentatum (C. Schweinf.) M.A. Clem.

\& D.L. Jones

C. latisegmentum (C. Schweinf.) M.A. Clem.

\& D.L. Jones

C. reineckeanum (Kraenzl.) M.A. Clem.

\& D.L. Jones

C. resupinatum (Forst. f.) Szlach.

C. taurinum (Rchb. f.) Szlach.

Cymbidium clypeolum (Forst. f. ) Willd.
C. equitans (Forst. f.) Sw.

C. pictum R. Br.

Dendrobium Sw.

D. biflorum (Forst. f.) Sw.

D. calcaratum A. Rich.

D. cheesmanae Guillaumin

D. dactylodes Rchb. f.

D. everardii Rolfe

D. goldfinchii sensu M. Hotta

D. involutum Lindl.

D. involutum sensu Kraenzl.

D. platygastrium Rchb. f.

D. separatum Ames

D. tokai Rchb. f.

D. triviale Kraenzl.

D. vaupelianum Kraenzl.

D. whitmeei Kraenzl.

Didymoplexis Griffith

D. micradenia (Rchb. f.) Hemsl.

D. minor J.J. Sm.

D. minor subsp. samoensis H. Fleischm. \& Rech.

D. neocaledonica Schltr.

D. pallens sensu Sykes

D. samoensis (H. Fleischm. \& Rech.) Schltr.

Epidendrum biflorum Forst. f.

E. clypeolum Forst. f.

E. equitans Forst.f.

E. fasciola Forst. f.

E. resupinatum Forst. f.

Epiphanes micradenia Rchb.f.

Eria myosurus (Forst. f.) Rchb. f.

E. sphaerocarpa Rchb. $\mathrm{f}$

E. stachyurus Rchb.f.

Erythrodes Blume

E. lilyana (H. Fleischm. \& Rech.) Schltr.

E. oxyglossa Schltr.

E. parvula Kores

E. purpurascens Schltr. in K. Schum. \& Lauterb.

Eulophia R. Br. ex Lindl.

E. minimiflora Kraenzl.

E. nuda Lindl.ex Wall.

E. pulchra (Thouars) Lindl.

E. spectabilis (Dennst.) Suresh

Eulophidium pulchrum (Thouars) Summerh.

Gastrodia sp. sensu Kraenzl.

Geodorum Jackson

G. densiflorum (Lam.) Schltr. 
G. furcatum sensu Kraenzl.

G. neocaledonicum Kraenzl.

G. pacificum Rolfe

G. pictum (R. Br.) Lindl.

G. tricarinatum Schltr.

Goodyera R. Br.

G. anomala Schltr.

G. biflora sensu Kraenzl.

G. discoidea (Rchb. f.) Schltr.

G. grandis (Blume) Blume

G. rubens Blume

G. rubicunda (Blume) Lindl.

G. rubicunda var. triandra (Schltr.) N. Hallé

G. triandra Schltr.

G. waitziana sensu H. Fleischm. \& Rech.

Habenaria Willd.

H. amplifolia Cheeseman

H. cyrtostigma Schltr.

H. papuana Kraenzl.

H. tradescantifolia Rchb. f.

$H$. tradescantifolia Rchb. f. var. pinquior

H. Fleischm. \& Rech.

Hetaeria Blume

H. discoidea (Rchb. f.) Schltr.

H. forcipata Rchb. f.

$H$. francisii Schltr.

H. oblongifolia Blume

H. polyphylla Rchb. f.

H. raymundii Schltr.

H. samoensis Rolfe

H. similis Schltr.

H. whitmeei Rchb. f.

Leptorkis elegans (Lindl.) Kuntze

L. gracilis (Hook. f.) Kuntze

Leucorchis micradenia (Rchb.f.) Benth. \& Hook.f. ex Drake

Limodorum densiflorum Lam.

L. veratrifolium Willd.

Liparis L.C. Rich.

L. clypeolum (Forst. f.) Lindl.

L. disepala Rchb. f.

L.elegans Lindl.

L. gracilis Hook. f.

L. layardii F. Muell.

L. mataanensis J.J. Sm.

L. stricta Schltr.

L. sp. 1 sensu Kraenzl.

Malaxis Sol. ex Sw.

$M$. brevidentata $\mathrm{C}$. Schweinf.

M. equitans sensu N. Hallé

M. glandulosa (Lindl.) Rchb. f.

M. latisegmenta C. Schweinf.
M. reineckeana (Kraenzl.) Kores

$M$. resupinata (Forst. f.) Kuntze

M. taurina (Rchb. f.) Kuntze

M. whitmeei (Rolfe) Kores

Microstylis reineckeana Kraenzl.

M. resupinata (Forst. f.) Drake

M. taurina Rchb.f.

M. whitmeei Rolfe

Monochilus Wall. ex Lindl.

M. plantagineus Rchb. f.

M. stenophyllus Rchb. f.

Neottia grandis Blume

N. rubicunda Blume

$N$. sinensis Pers.

Nervilia Commerson ex Gaudich.

$N$. aragoana Gaudich.

N. concolor (Blume) Schltr.

Oberonia Lindl.

O. brevidentata (C. Schweinf.) Parham

O. brevifolia sensu Seem.

O. aff. diura sensu Christoph.

O. equitans (Forst. f.) Mutel

O. flexuosa Schltr.

$O$. glandulosa Lindl.

O. latisegmenta (C. Schweinf.) Parham

O. micrantha A.Rich.

O. palmicola sensu Parham

Orchis triplicata Willemet

Pedilonum separatum (Ames) Rauschert

P. triviale (Kraenzl.) Rauschert

Peristylus Blume

P. minimiflorus (Kraenzl.) N. Hallé

$P$. novoebudarum F. Muell.

P. papuanus (Kraenzl.) J.J. Sm.

P.tradescantifolius (Rchb. f.) Kores

Phaius Lour.

P. amboinensis Blume

P. graeffei Rchb. f.

$P$. robertsii F. Muell.

P. tankervilleae (Banks ex L'Herit.) Blume

$P$. terrestris sensu Ormerod

Phreatia Lindl.

$P$. collina Schltr.

P. graeffei Kraenzl.

P. macrophylla Schltr.

P. matthewsii Rchb. f.

P. micrantha (A. Rich.) Lindl.

P. multiflora sensu Kraenzl.

P. myosurus (Forst. f.) Ames

P. neocaledonica Schltr.

$P$. reineckei Schltr.

P. robusta R.S. Rogers 
P. samoensis (Kraenzl.) Schltr.

$P$. sarcothece Schltr.

P. upoluensis Schltr.

P. yunckeri L.O. Williams

Physurus Rich.

P. lilyanus H. Fleischm. \& Rech.

Pogonia concolor Blume

$P$. flabelliformis Lindl.

P. nervilia Blume

Rhamphidia discoidea Rchb. f.

R. tenuis sensu H. Fleischm. \& Rech.

Rhynchophreatia micrantha (A. Rich.) N. Hallé

Robiquetia Gaudichaud

R. tongaensis P.J. Cribb \& Ormerod

Saccolabium papuanum Schltr.

Spathoglottis Blume

S. angustifolia (Gaudich.) Benth. \& Hook. f.

S. daenikeri Kraenzl.

S. pacifica sensu Kraenzl.

S. plicata Blume

S. unguiculata auct., non (Labill.) Rchb.f.

S. vieillardii Rchb. f.

Spiranthes Rich.

Spiranthes neocaledonica Schltr.

S. sinensis (Pers.) Ames

Taeniophyllum Blume

T. asperulum Rchb.f.

T. decipiens Schltr.

T. fasciola (Forst. f.) Seem.

T. fasciola var. mutina N. Hallé

T. parhamiae L.O. Williams

T. seemannii Rchb. f.

Thelasis samoensis Kraenzl.

Trachoma papuanum (Schltr.) M.A. Clem.,

J.J. Wood \& D.L. Jones

T. societatas (J.W. Moore) N. Hallé

Tuberolabium Yamamoto

T. papuanum (Schltr.) J.J. Wood ex B.A. Lewis \& P.J. Cribb

Vanilla Plum. ex Mill.

V.planifolia Andrews

Vrydagzynea Blume

V. vitiensis Rchb. $\mathrm{f}$.

$V$. whitmeei Schltr.

Wolfia spectabilis Dennst.

Zeuxine Lindl.

Z. betchei Schltr.

Z. sphaerocheila H. Fleischm. \& Rech.

Z. stenophylla (Rchb. f.) Benth. \& Hook.f.

ex Drake

Z. triandra M. Hotta 
